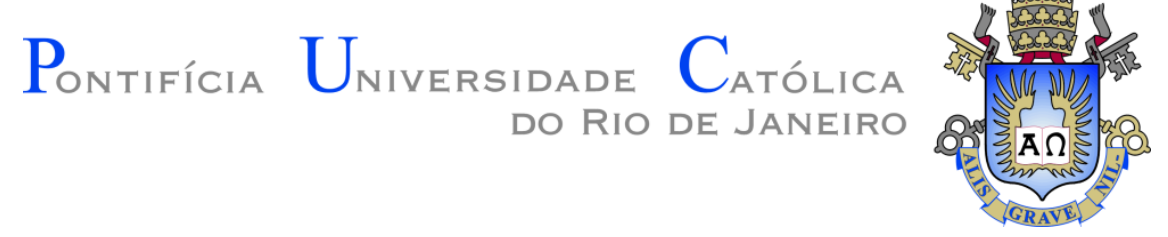

Francicleo Castro Ramos

A experiência escolar do mundo popular e os desafios de uma socialização para maior equidade no Brasil

Dissertação de Mestrado

Dissertação apresentada ao Programa de Pósgraduação em Ciências Sociais da Pontifícia Universidade Católica do Rio de Janeiro (PUCRio), como requisito parcial para a obtenção do título de Mestre em Ciências Sociais.

Orientador: Prof. Marcelo Baumann Burgos

Rio de Janeiro

Abril de 2014 


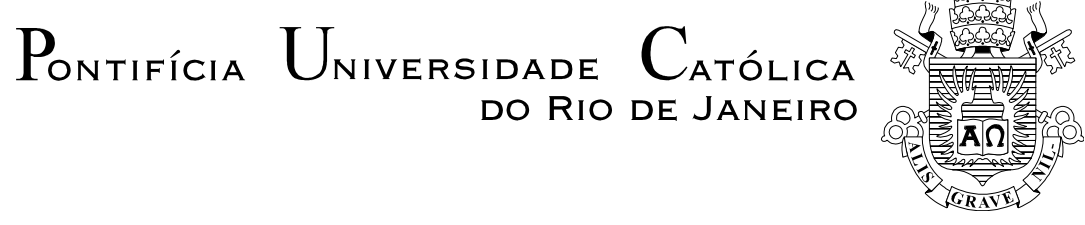

Francicleo Castro Ramos

\section{A experiência escolar do mundo popular e os desafios de uma socialização para maior equidade no Brasil}

Dissertação apresentada como requisito parcial para obtenção do grau de Mestre pelo Programa de Pós-Graduação em Ciências Sociais do Departamento de Ciências Sociais do Centro de Ciências Sociais da PUC-Rio. Aprovada pela Comissão Examinadora abaixo assinada.

Prof. Marcelo Tadeu Baumann Burgos

Orientador Departamento de Ciências Sociais - PUC-Rio

Profa. Mônica Dias Peregrino Ferreira UERJ

Profa. Angela Maria de Randolpho Paiva Departamento de Ciências Sociais - PUC-Rio

Profa. Mônica Herz

Coordenadora Setorial do Centro de Ciências Sociais - PUC-Rio

Rio de Janeiro, 24 de abril de 2014 
Todos os direitos reservados. É proibida a reprodução total ou parcial do trabalho sem autorização da universidade, do autor e do orientador.

\section{Francicleo Castro Ramos}

Graduou-se em Ciências Sociais pela PUC-Rio (2011). Pesquisador do Centro de Políticas Públicas e Avaliação da Educação - CAEd/UFJF, membro do Núcleo de Estudos sobre Escola, Sociedade e Democracia (PUC-Rio/CAEd/UFJF). Tem interesse em Sociologia da Educação, Políticas Públicas Educacionais, Sociologia Urbana, Teoria Social Clássica e Contemporânea e Metodologias de Pesquisas Sociais.

Ficha Catalográfica

Ramos, Francicleo Castro

A experiência escolar do mundo popular e os desafios de uma socialização para maior equidade no Brasil / Francicleo Castro Ramos ; orientador: Marcelo Baumann Burgos. -2014.

120 f. ; $30 \mathrm{~cm}$

Dissertação (mestrado)-Pontifícia Universidade Católica do Rio de Janeiro, Departamento de Ciências Sociais, 2014.

Inclui bibliografia

1. Ciências Sociais - Teses. 2. Escola pública. 3. Socialização escolar. 4. Mundo popular. 5. Experiência escolar. 6. Equidade no Brasil. I. Burgos, Marcelo Baumann. II. Pontifícia Universidade Católica do Rio de Janeiro. Departamento de Ciências Sociais. III. Título. 
Dedico este trabalho aos meus avós Edson dos Santos Castro e Emídia Bruzaca Castro e à minha tia Enilda Maria Bruzaca Castro. Pelos belos sorrisos com os quais me criaram. 


\section{Agradecimentos}

Quero agradecer, em especial, ao meu orientador Marcelo Burgos, que me acompanha desde a graduação e nunca deixou de ser muito paciente, atencioso e dedicado, mesmo nas vezes em que as minhas argumentações não passavam de simples palavras confusas. Marcelo Burgos tem me ensinado o que é ciências sociais, ser cientista social e encarado as minhas angústias como uma oportunidade para orientar o meu olhar; tem sido generoso em apostar no meu trabalho e, por isso, tive a felicidade de me engajar ainda mais na sociologia. Portanto, todo o meu reconhecimento por me formar nesses anos de muito aprendizado. Sem dúvida, Marcelo Burgos é um exemplo de intelectual e pesquisador a ser seguido.

Agradeço ao professor Sampaio, vice-reitor comunitário, por dispor canais de diálogo aos estudantes, em particular aos bolsistas no âmbito da graduação. No meu caso, o término do mestrado é o fechamento de um ciclo de experiência com a PUC que se iniciou na graduação e, desse modo, reconheço o quão importante foi o professor Sampaio ao defender a importância dos "suportes" para o bolsista permanecer e concluir a universidade. Agradeço ainda a generosidade com que tratou as reivindicações que participei enquanto estudante mobilizado. Todo o meu reconhecimento pela sua paciência.

Quero agradecer aos professores do departamento de Ciências Sociais pela disponibilidade e por estimular uma discussão qualificada nos cursos. Obrigado 
Santuza Cambraia Neves, Sônia Giacomini, Maria Alice Rezende de Carvalho e Werneck Vianna pelos ensinamentos; obrigado Ricardo Ismael também pelo retorno dos trabalhos.

Agradeço às secretárias Mônica e Eveline pelo carinho e, em especial, a Ana Roxo pela dedicação e orientações, sempre bem pedagógicas, nas questões referentes à burocracia da pós.

Aos membros da banca examinadora. Professora Angela Paiva contribuiu inestimavelmente para esse momento, como também possibilitou um amplo acesso a importantes bibliografias durante o curso. À Mônica Peregrino agradeço pelo direcionamento ao colocar intervenções fundamentais para entender a escola nos dias atuais. Agradeço a essas professoras pela dedicação mostrada no exame de qualificação.

À professora Sarah Silva Telles que acompanhou a minha formação e sempre foi muito atenciosa ao me ouvir falar; agradeço a confiança e a aceitação da suplência para a defesa da dissertação.

À PUC-RIO e à Coordenação de Aperfeiçoamento de Pessoal de Nível Superior (CAPES) pelas concessões de bolsa de estudos para o desenvolvimento deste trabalho.

Ao grupo de pesquisa Gestão Escolar e Territórios Populares pelo intenso aprendizado a partir das discussões de textos e realização de atividades de campo. À Mariana Junqueira, Sarah Laurinho, Maria Larissa e Fernanda Lopes, como também Rafael Dutton, agradeço o apoio e carinho durante todos esses anos juntos. Agradeço especialmente a Ana Carolina Canegal e Laura Rossi pela parceria e respeito mútuo.

Agradeço a parceria de Camila Amora, uma frô que sabe ser companheira no diaa-dia, além de ser um amor que proporciona felicidade e muitas reflexões nas conversas que temos, especialmente pela sua postura crítica construtiva.

Agradeço a minha família pelo carinho, apoio, confiança e estímulo: Almerinda Castro Ramos, Maria José e Maria do Socorro Bruzaca Castro são mulheres guerreiras; admiro a ousadia de como lidam com as eventualidades da vida. Aos 
meus irmãos Cilene e Acilio pela força; ao meu tio Genival pelas pertinentes intervenções e sabedoria de vida.

Quero agradecer aos amigos Gláucio Maciel, Dirceu Alves, Jonas Dias Érica Conceição, Alexandre Nascimento, Taiguara Moreira e Anderson Ferreira pelo apoio e por entenderem o momento de produção da dissertação. De modo especial, agradeço ao Thiago Fernandes por ter se colocado como um bom interlocutor, por fazer boas críticas às ideias centrais deste trabalho.

Por fim, agradeço aos muitos colegas da PUC, como Bruninho, Brunão, Moxquito, Cássio, Alex, Viviane de Salles, Vanusa Queiroz, Thelma Lersch... Não posso terminar sem agradecer a cordialidade de Olívia Hirsch, Anastácia Cristina e Joana Macedo nos dias de "favelinha", um anexo do departamento e lugar de escrita e pesquisa dos pós-graduandos de Ciências Sociais. Com elas o dia a dia da dissertação se tornou uma troca de experiência em busca de conhecimentos. Agradeço também ao Paulo Duran e Luiz Fernando pelo constante apoio demonstrado em conversas pelos corredores da universidade. 


\section{Resumo}

Ramos, Francicleo Castro; Burgos, Marcelo Baumann (Orientador). A experiência escolar do mundo popular e os desafios de uma socialização para maior equidade no Brasil. Rio de Janeiro, 2014. 120p. Dissertação de Mestrado - Departamento de Ciências Sociais, Pontifícia Universidade Católica do Rio de Janeiro.

A presente dissertação busca compreender a socialização produzida pela escola brasileira no contexto de universalização do ensino. Para tanto, apresentase episódios de uma etnografia de recreio de quatro escolas públicas de ensino fundamental da cidade do Rio de Janeiro a fim de identificar os seus limites e suas potencialidades no trabalho de socialização dos estudantes de origens populares. Conclui-se que a Constituição de 1988 confere uma centralidade à escola na socialização de todas as crianças e, segundo seus princípios, uma de suas funções é desenvolver a habilidade no indivíduo para agir na sociedade de modo a fortalecer a democracia. Com efeito, como a interação escolar é marcada pelos efeitos da condição social do aluno morador de favela, os episódios de recreio dão indícios de uma socialização na qual há pouca reciprocidade de expectativas, e esse formato pode gerar uma integração precarizada na sociedade. Além disso, as diferentes formas observadas de socialização escolar apresentam baixa capacidade de ofertar aos alunos das classes populares a possibilidade de experimentar igualmente as instituições da democracia e as potencialidades educacionais atuais.

\section{Palavras-chave}

Escola pública; socialização escolar; mundo popular; experiência escolar; equidade no Brasil. 


\section{Abstract}

Ramos, Francicleo Castro; Burgos, Marcelo Baumann (Advisor). The school experience of lower-class students and the challenges of a socialization for greater equity in Brazil. Rio de Janeiro, 2014. 120p. MSc. Dissertation - Departamento de Ciências Sociais, Pontifícia Universidade Católica do Rio de Janeiro.

The present dissertation aims to comprehend the socialization produced by the Brazilian school in the context of educational expansion. Thus, it presents ethnographical field situations of school recesses in four elementary public schools in Rio de Janeiro, in order to identify limits and potentialities of the socialization of lower-class students. The Brazilian Constitution of 1988 confers centrality to public schools in the socialization of all children and, according to its principles, one of school's task is to develop individuals capacity to act in society to strengthen democracy. Since the educational interaction suffers the effect of the social condition of the student, majorly 'favela' inhabitant, the recess situations seem to indicate a socialization in which there is a low expectation of reciprocity that may produce a fragile integration in society. Furthermore, the different ways of socialization observed offered low possibilities to lower-class students equally experiment democracy and educational potentialities.

\section{Keywords}

Public school; school socialization; lower-class students; school experience; equity in Brazil. 


\section{Sumário}

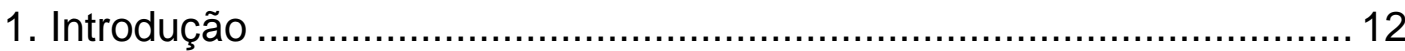

2. Sobre o trabalho de socialização escolar .............................................. 19

2.1 Sistema e consenso social ou a condição do indivíduo em face às

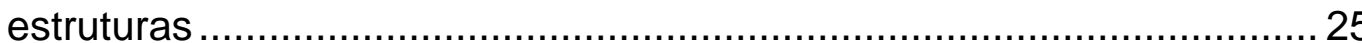

2.2 A afirmação do sujeito na unidade social: sujeitos intensificando a

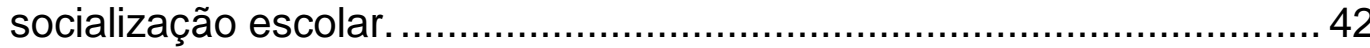

3. Cultura escolar e socialização escolar no Brasil ....................................56

3.1 A oferta da escola pública às classes populares no Brasil................57

3.2 As qualidades de sua expansão: cultura escolar como ponto de visão da relação no interior da escola..................................................... 72

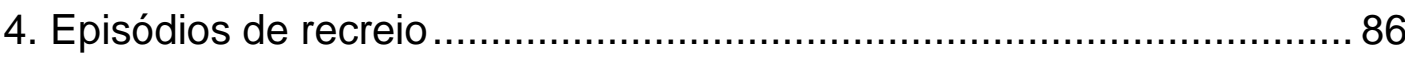

4.1 Recreio: espaço-tempo visto por episódios ....................................... 86

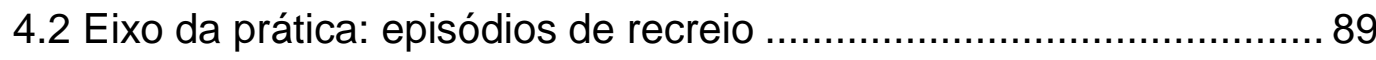

4.2.1 Primeiro episódio - escola 01: o funk no recreio............................ 89

4.2.2 Segundo episódio - escola 02: o boné e o papel higiênico............ 91

4.2.3 Terceiro Episódio - escola 03: da educação física à sala de aula 94

4.2.4 Quarto Episódio - escola 04: na sala da direção.......................... 95

4.3. Eixo de análise: problematizando os episódios................................98

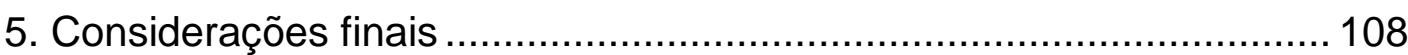

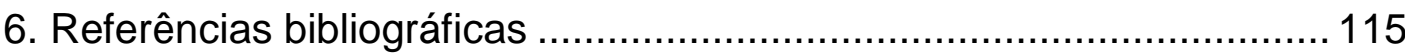


A pesquisa constitui um meio, não um fim em si mesmo. A pesquisa pela pesquisa é tão abominável quanto o pensamento puramente especulativo... A ciência visa a explicar a realidade, o que confere um fim à pesquisa e dá pleno sentido às atividades intelectuais dos cientistas.

Florestan Fernandes 


\section{Introdução}

A escola é uma realidade nos diferentes contextos da vida de famílias brasileiras. O projeto escolar adentra os espaços das expectativas coletivas e individuais, mas não dá garantia de sucesso a todos; apesar de seu resultado ser legitimado, a escola não impede que uma parcela importante de seu público fique à deriva da apropriação de valores e capitais na sociedade. Ainda assim, a escolarização é uma medida de consenso universal para credenciar as posições sociais atuais.

Essa assertiva é decorrente de um fenômeno global que pode ser compreendido como algo inerente à própria natureza da democracia contemporânea. O fenômeno global a que estamos nos referindo é o processo de universalização do ensino, que, hoje, no Brasil, consiste na ampliação da oferta do Ensino Fundamental como uma socialização obrigatória para todas as crianças e adolescentes deste país. Se, por um lado, a ampliação do acesso à escola trata-se de um fenômeno autônomo, independentemente das vontades particulares, por outro, especialmente aqui, nestas terras de desiguais, não deixa de revelar uma forma de combater as injustiças sociais. Mas, como um dever sociológico, e ressaltando que, evidentemente, não se trata de negar o avanço, devemos chamar a atenção para o fato de que o acesso à escola, por si só, não produz equidade, não resolve a questão da injustiça; o acesso para uma maior equidade social requer tanto mudanças nas formas institucionais quanto na dinâmica da sociedade em geral.

Então, reclamar dessa razão de que o acesso à escola não produz equidade não significa apontar a instituição escolar como a única culpada pelos fracassos escolares das experiências individuais, bem como a manutenção das desigualdades sociais. O fato é que, ao levantar essa reclamação, estamos de acordo com o diagnóstico de que é preciso um enorme esforço para os resultados escolares se tornarem uma base da equidade social. Esse desafio parece ser um dos mais refinados calcanhares de Aquiles da sociedade brasileira, uma vez que, a 
substituição da socialização do mundo do trabalho ou mesmo a da esfera religiosa pela socialização de natureza escolar, lança a tarefa de realizar uma estruturação do sistema de ensino, que barre, na porta da escola, os efeitos perversos de uma sociedade cuja história mostra uma difícil relação com a igualdade.

De certo modo, uma de nossas preocupações nesta dissertação é compreender como essa complexidade tem se dado na escola pública brasileira. E, partindo da compreensão de que "as transformações da escola e da vida social desestabilizaram profundamente as condições de trabalho pedagógico" (DUBET, 2008: 118), nossa opção de navegação sociológica é a investigação da socialização escolar de crianças e adolescentes do mundo popular. Uma exploração específica dessa investigação é analisar a forma de como a escola pública lida com o seu aluno e também com o mundo dele. Então, dito de outra maneira, a presente dissertação busca compreender a forma como a escola pública se relaciona com os seus estudantes, sendo a relação estabelecida com o mundo deles o ponto privilegiado dessa relação, a fim de pensar o processo de socialização escolar dos estudantes de origens populares.

Apesar de nos dias atuais não se tratar de uma preocupação central da sociologia, a socialização faz parte das questões que fundam a análise sobre a relação indivíduo e sociedade, e, por essa razão, está presente na teoria social clássica e contemporânea. Como sabemos, por isso fala-se em toda parte, diversas dimensões da vida social caracterizam as formas de socialização, mas, atualmente, quase não a problematizamos. É bom registrar que a socialização é um processo profundamente disseminado e composto por espaços plurais de "múltiplas referências identitárias" (SETTON, 2011: 713); que o impulso da globalização forjou inúmeras possibilidades de desenvolvimento da socialização, tornando seus campos muito mais heterogêneos.

Por outro lado, conforme Nóvoa (2001), a socialização escolar também foi intensificada a partir da centralidade conferida à escola com a tarefa de inserção de novas camadas sociais, sendo a universalização da escolaridade uma evidência da difusão mundial da escola em diferentes contextos nacionais. Então, embora a modernidade globalizada venha oferecendo um complexo ambiente no qual o indivíduo e os grupos sociais encontram condições de se forjarem (SETTON, 
2011), não quer dizer que haja uma substituição do modo escolar de socialização. No entanto, a socialização escolar está sendo constantemente desafiada. Um dos desafios diz respeito à habilidade de desenvolver uma rotina capaz de envolver os alunos na aquisição de saberes da cultura escolar. Antigamente, esse desafio não existia porque na sociedade à classe popular correspondia o mundo do trabalho. Esse é um ponto que está presente na reflexão de Dubet (2008) sobre a desestabilização das "condições pedagógicas", que, no limite, problematiza a própria capacidade da escola de ser justa com os destinos de seus alunos.

Afinal, qual é o papel da escola? A escola é potencialmente capaz de mudar a realidade social? A sociologia da educação sugere uma polarização nas respostas a esses questionamentos. De um lado, uma perspectiva que aborda a escola como uma instituição que valoriza o capital sociocultural legitimado e, desse modo, torna-se cúmplice da reprodução do modelo social dominante. De outro, uma visão mais otimista que confere à escola a função de formar recursos humanos para o desenvolvimento econômico e social. Rapidamente, vamos entender essa polarização.

A interpelação sobre o papel da escola na sociedade é uma dimensão presente nas investigações de Pierre Bourdieu, teórico e pesquisador que dedicou uma parte importante de seus trabalhos à educação. No decorrer dos anos 60-80 do século XX, o esforço de explicar o que a escola produz [se era mobilidade ou reprodução] foi magistral pela sua originalidade tanto que se tornou um marco nas pesquisas sobre os processos de escolarização, a ponto de impulsionar a criação da chamada sociologia da reprodução. Esta sociologia, largamente, denunciou a relação entre sistema de ensino e estruturas de classes sociais.

Pierre Bourdieu escreveu em parceria com Jean Passeron uma obra dedicada a esmiuçar como a instituição escolar é transformada em um forte aparelho de manutenção das relações de poder. Na perspectiva de Bourdieu e Passeron (1975), ao introjetar a estrutura social existente, as práticas pedagógicas da escola reproduzem e legitimam o poder da classe social dominante. Diante disso a instituição escolar não é instrumento de transformação do padrão de estratificação vigente, pelo contrário, concretiza-se como um mecanismo eficaz na sublimação da dominação das camadas populares. 
Esse modelo de análise da escola, que a entendia como uma peça do conjunto social, com suas disputas socioculturais refletindo na formação do indivíduo e das classes, encontra um notável apoio na perspectiva dos estudos neo-institucionalistas. Um sociólogo representante desta perspectiva é o americano John Meyer. Ao refletir os efeitos da escola na sociedade, Meyer (1977) também vai assinalar o caráter reprodutivista dessa instituição por meio de seu poder de chancelar as melhores posições sociais. Segundo o autor, a escola possui sistemas de classificação que organiza todo o processo de escolarização em torno das credenciais que conferem um lugar na sociedade, sendo seus resultados amplamente difundidos e perfeitamente legitimados pelos Estados. Para ele, tratase de um allocation system que confere sucesso e fracasso na sociedade aos indivíduos que passaram, como também aos que não passaram, pela instituição escolar.

O entendimento de John Meyer é que a educação escolar ganhou uma enorme centralidade e, com isso, ganha também relevância esse sistema de alocação, consagrando a escola no centro dos mecanismos globais de seleção. Essa centralidade tornou a escola uma instituição altamente poderosa nas sociedades modernas. Mas, por que a escola ganhou um lugar central no ideário contemporâneo? A resposta é que à instituição associou-se uma crença de criar modelos sociais mais desenvolvidos político e economicamente. Segundo Meyer (1977), assim como também assinalam Chabbott e Ramirez (2000), a escola ganha, no plano global das nações, um lugar importante na produção da cultura democrática e torna-se uma instituição fundamental para o desenvolvimento socioeconômico de todo país.

Néstor López (2005) é outro sociólogo que vai identificar essa centralidade da escola na ordem econômica e na formação para a cidadania. O seu argumento para esse diagnóstico é que a corrente de pensamento chamada "otimismo pedagógico" teve um importante papel na difusão dessa crença. Esta corrente, na passagem da década de 1980 para a de 1990, contrapôs-se à sociologia reprodutivista e deu forte ênfase à potencialidade da escola de escolarizar os indivíduos independentemente de sua origem social. Mas, segundo o sociólogo 
argentino (2005), essa aposta da eficácia escolar é desafiada com o aprofundamento do processo de massificação da escola.

Ao problematizar essas duas correntes de compreensão da escola na contemporaneidade, López (2005) fala em limites e recoloca o problema da relação escola e sociedade. Fazendo a opção de não apostar em nenhuma das correntes, nem a do reprodutivismo e nem a do otimismo pedagógico, o pesquisador afirma que a escola é especialmente desafiada a atuar em contextos que conjugam desigualdades sociais e diversidade cultural, como são as sociedades latinoamericanas. Na realidade, o que López quer chamar a atenção é para a necessidade dos grupos sociais mais prejudicados em capitais (materiais e simbólicos) de efetivamente poderem participar do processo educativo formal.

Ao fazer a crítica das duas correntes, López não defende que a escola seja uma instituição de reprodução da estrutura de poder; ele também não acredita no otimismo que considera todos os alunos iguais a tal ponto de privilegiar os mais próximos da cultura escolar. A sua perspectiva sociológica combina escola e equidade social, e explorando essa relação o pesquisador apresenta o conceito de "educabilidade" como uma categoria analítica capaz de reforçar a importância da escola se aproximar do aluno real. Pois, assim, para López, é possível oferecer igualdade à aprendizagem.

Esse é um dos desafios colocados pela universalização ou massificação da escolarização fundamental, cujo processo tem complexificado o papel e a potencialidade da escola nos dias atuais. Assim como as escolas de outros países da América Latina, tal como aponta o sociólogo argentino, a escola brasileira está sendo interpelada a redefinir suas práticas de escolarização, suas condições pedagógicas, de modo a considerar efetivamente os contextos sociais dos alunos. Porém, é importante dizer que os efeitos da massificação não são os mesmos em todos os países, bem como vale ressaltar que a massificação escolar encarada nesse trabalho é a afirmação da escola como central no processo de socialização de todas as crianças de uma sociedade.

O que está sendo posto é uma ênfase sobre as mudanças institucionais como efeitos da universalização do ensino. No caso do Brasil, foco de nossa 
análise, a massificação redesenha o perfil institucional da escola (cf. Capítulo 03) produzindo mudanças profundas nas interações escolares e forja uma qualidade que tende a aprofundar o quadro de desigualdade educacional, como é possível problematizar com o capítulo 04. Conforme veremos no curso desta dissertação, se a massificação diversificou a entrada na escola, ela também consagrou a escola pública como a escola dos pobres, e, especialmente devido à precarização e alteração de suas funções (cf. Capítulo 03), essa mudança converge para uma expansão e/ou aprofundamento das desigualdades educacionais.

Por essa razão, então, a preocupação mais geral do presente trabalho é investigar o quadro de socialização escolar de crianças e adolescentes do mundo popular brasileiro, pois ao explorar esta forma de socialização é possível compreender o lugar da escola pública na nossa sociedade e colocar em debate a experiência escolar dos alunos de origens populares. Para a investigação desse problema sociológico acreditamos ser importante entender as formas de relações da escola com o mundo do aluno - uma categoria que fala sobre um conjunto de aspectos da sociabilidade do estudante definida fora dos muros da escola. E para enxergar o mundo do aluno na escola adotamos a cultura escolar como um importante ângulo de observação da relação entre essa instituição massificada e o seu público.

Portanto, preocupado em explorar a socialização produzida pela escola, a presente dissertação busca compreender a forma como a escola pública se relaciona com os seus estudantes, sendo a maneira de lidar com o mundo deles o ponto privilegiado dessa relação, a fim de pensar o processo de socialização escolar dos estudantes de origens populares. Para tanto, apresenta-se episódios de recreio como uma importante via de exploração dessa dinâmica, com vistas a extrair aspetos da prática pedagógica a fim de identificar os limites e potencialidades da escola no trabalho de socialização.

Antes de falar especificamente dos capítulos, importa registrar que a investigação sobre a relação entre a escola pública e o mundo do aluno é uma questão que tem estimulado o grupo de pesquisa Gestão Escolar e Territórios 
Populares ${ }^{1}$. Desde 2008 tenho participado desse grupo de pesquisa que abriu diversas frentes de investigação para tentar compreender o processo educacional de crianças e adolescentes a partir de nove escolas municipais situadas na zona sul da cidade do Rio de Janeiro. Como frente de trabalhos o grupo realizou, entre outras atividades, investigação envolvendo o Conselho Tutelar na sua relação com a escola; entrevistas com pais/responsáveis de/por estudantes com o objetivo de saber a perspectiva e a expectativas em face dessas escolas; e, mais recentemente, observação de recreio. Apropriei-me de parte do material da observação de recreio para o desenvolvimento desta dissertação e, evidentemente, beneficiei-me de inúmeras questões refletidas coletivamente no grupo.

A presente dissertação apresenta no capítulo 02 (o capítulo 01 é esta introdução) uma discussão sobre o trabalho de socialização escolar, com base em autores da sociologia clássica e contemporânea, visando extrair subsídios para analisar a dinâmica escolar mostrada nos episódios de recreio. No capítulo 03 está presente uma resenha bibliográfica de parte da sociologia da educação brasileira e a principal preocupação é pensar o processo de afirmação da escola no Brasil para as classes populares, atentando para os dilemas educacionais cujos efeitos são percebidos nas interações que permeiam o recreio. Por fim, o capítulo 04 apresenta a observação de recreio apresentada por episódios e problematiza as situações encontradas a partir do esforço de articular ferramentas de análises vistas nos capítulos 02 e 03 . As considerações finais, por sua vez, apresentam alguns pontos que podemos considerar como resultados da investigação, uma interpretação do que os dados sugerem.

\footnotetext{
${ }^{1}$ O grupo de pesquisa Gestão Escolar e Territórios Populares é coordenado pelos professores Marcelo Burgos, do departamento de Ciências Sociais da PUC-Rio, e Ralph Bannel, do departamento de Educação da mesma instituição. O grupo conta com a participação de alunos da graduação e pós-graduação e as atividades realizadas no decorrer dos cinco anos de sua existência estão sendo organizadas em um livro a ser lançado em outubro de 2014.
} 


\section{Sobre o trabalho de socialização escolar}

A qualidade da interação ocorrida no interior das escolas públicas, como veremos no capítulo do recreio, depende de um conjunto de esforços tanto dos alunos quanto dos profissionais da escola. A reflexão sobre a dinâmica e a complexidade dessa relação, no âmbito da teoria social, diz respeito ao processo de socialização escolar que coloca em jogo a difícil tafera de executar o projeto que lhe foi posto e revela as tensões próprias dessa realização. A discussão sobre socialização escolar na plano teórico mais amplo está ancorada na relação indivíduo e sociedade, que nos permite pensar as funções das instituições sociais e o próprio modo de como se afirmam os indivíduos e/ou as classes, seja para ambientes com segmentações sociais mais claramente definidas, como a sociedade moderna, seja para contextos sociais em que o fluxo da sociedade assume a forma de múltiplos sentidos, como os dias atuais.

A sociedade pode ser compreendida como um processo de constante renovação, e as renovações de natureza democrática conferem centralidade de poderes às instituições, acreditando serem elas são as mais credenciadas para o exercício dos princípios democráticos. Ora, em uma democracia as instituições são forjdas para uma perspectiva universalista. A exemplo disso, temos a escola com o desafio de socializar todas as crianças. Como realizar a socialização escolar de todas as crianças de uma sociedade? Trata-se de uma pergunta que traz em seu núcleo a problematização daquilo que, hoje, precisamos enfrentar: melhorar a qualidade da educação escolar. O fato é que ao falar-se em melhoria da qualidade da educação escolar, estar-se-à falar do sucesso do "modo escolar de socialização" realizado pela instituição "Escola"2.

Este capítulo tem a pretensão mais geral de organizar uma reflexão em torno do tema "socialização escolar". Com a disscussão dessa questão sociológica,

\footnotetext{
${ }^{2}$ Vincent, Lahire e Thin (2001) discutem o sentido de crise da escola atual a partir da noção de forma escolar e a diferenciam da instituição "escola". Para eles, a crise de que tanto se fala não é sobre o modo escolar de socialização, mas da capacidade da escola em realizar essa tarefa.
} 
pretende-se extrair ferramentas de análises para a compreensão da socialização escolar brasileira e problematização de suas expressões vistas a partir dos episódios de recreio apresentados no terceiro capítulo.

É constitutiva nas ciências sociais a questão da relação entre indivíduo e sociedade. Autores como Karl Marx (1818-1883), Émile Durkheim (1858-1917), Max Weber (1864-1920), Norbert Elias (1897-1990), Erving Goffman (19221982) e Pierre Bourdieu (1930-2002), entre outros, adotaram diferentes perspectivas de análise desse complexo processo de formações que constitui a sociedade e os campos de interação com os indivíduos. Como se sabe, com as categorias de análises, podemos compreender algumas das questões sociais e individuais que fazem parte de situações específicas, como as vivências cotidianas e a relação entre elas e os quadros sociais mais amplos - do tipo abordagem estrutural. Elas permitem atender, por exemplo, à preocupação metafórica de G.W.F. Hegel (1770-1831), cuja ênfase está na importância de não se perder de vista a floresta só porque uma árvore está à frente, ao mesmo tempo que não é rico ficar preso à totalidade. Portanto, as categorias de análises permitem olhar a árvore e a floresta ao mesmo tempo e servem à produção social do conhecimento. Embora não se limitem a situações históricas, vale dizer, reagem melhor ao seu tempo ${ }^{3}$. Sem categorias não há conhecimento sociológico. Indivíduo e sociedade, em suas diferentes expressões, são categorias que ultrapassam as fronteiras do tempo/espaço e servem de base para a apreensão da complexa realidade societária ${ }^{4}$.

\footnotetext{
${ }^{3}$ Ver, por exemplo, o trabalho de Karl Mannheim (1986) que investiga os modos de pensamento e os condicionamentos sociais em Ideologia e Utopia. Compreender essa relação nos permite considerar que o conhecimento não é apenas fruto de envergaduras teóricas do indivíduo, mas também é forjado pela própria disposição social na qual o indivíduo está inserido na vida. Então, pode-se dizer que o movimento do pensamento é identificado com o movimento da vida.

${ }^{4}$ Sobre a pertinência das categorias, a teoria do conhecimento de Durkheim (1996) as consagra como uma necessidade moral para a vida intelectual, por exprimirem "coisas sólidas", diz ele: [as categorias] elas aparecem (...) como hábeis instrumentos de pensamento que os grupos humanos laboriosamente forjaram ao longo dos séculos nos quais acumularam o melhor de seu capital intelectual. Toda uma parte da história da humanidade nelas se encontra como que resumida (p. XXVII)
} 
A relação indivíduo e socidade tem sido refletida em diversas dimensões. Essa relação pode ser vista em Marx sob a dimensão da luta pela liberdade humana assinalada no dramático diagnóstico do entrelaçamento dos grupos com base em uma sociedade de classe produtora de opressões, sobretudo, via dominação do capital sobre o trabalho. Esse problema da liberdade, bastante enfatizado pela teoria política do século XVII e século XVIII, pode ser visto em $O$ Manifesto Comunista (1997) que, apesar de ter seu foco voltado para a relação entre as classes sociais, apresenta o processo de constituição da sociedade capitalista, mas também da emancipação do indivíduo, cuja conquista se daria com uma sociedade sem classes através da luta revolucionária do proletariado. Nesse sentido, a emancipação individual é um horizonte a ser alcançado no contexto das lutas entre as classes sociais, uma vez que, na dinâmica modernizadora da sociedade capitalista, os comportamentos e percursos individuais estão condicionados às classes que pertencem à estrutura de organização da sociedade, sendo essa especialmente marcada pelas relações de produção. Marx, ao interpretar a realidade social com base na dominação de uma classe sobre a outra, entende a escola como mantenedora dessas relações de poder que proporcionam a hierarquização social.

Nessa ordem de dicotomia das classes sociais há a primazia dos valores sociais, claramente burgueses, sobre os dos proletariados e, por isso mesmo, há a iminência do conflito, sendo a escola fundamental na tarefa de controlar essas tensões a partir da inculcação dos valores da burguesia. Pela questão da manutenção da ordem, evidentemente considerando as notáveis diferenças de perspectivas de sociologias, é possível fazer uma correlação dessa análise com as de Durkheim, mesmo sabendo que as sociologias desses autores vão além dessa questão. Nesse paralelo que está sendo estabelecido entre os autores, a título de desfazer qualquer confusão, vale dizer que em Marx e em Durkheim a questão da emancipação da classe e do indivíduo, respectivamente, aparece de diferentes maneiras e esse ponto vai estar presente no decorrer da abordagem realizada mais à frente.

O fato é que neste primeiro momento importa dizer que a complexa relação entre o indivíduo e a sociedade em Durkheim aparece na sua preocupação 
com o processo de coesão, integração e manutenção da sociedade. $\mathrm{Na}$ abordagem desse problema, Durkheim coloca como questão central o desafio de conciliar consciência coletiva e consciência individual. Pois, no seu entendimento, a sociedade consiste em um esforço de manter e de revigorar sentimentos coletivos porque, através deles, é forjada a sua unidade. E, justamente por isso, seus escritos são bem enfáticos ao definirem a sociedade não como uma coleção de indivíduos, mas como um conjunto de instituições que se "coisificam" através das ações individuais. Às instituições é concebida uma dimensão constitutiva da moralidade social, e nisso está presente a socialização das formas de agir, pensar e sentir que fazem parte mesmo da sustentação da sociedade. Durkheim entende que esse processo é experimentado pessoalmente como processo coercitivo, uma vez que o poder da sociedade age de modo a deixar claro que sua natureza não corresponde a um conjunto de consciências individuais, mas de uma consciência coletiva. Portanto, a questão da socialização é crucial na reflexão de Durkheim sobre a relação entre indivíduo e sociedade.

Assim como Marx e Weber, Durkheim estava interessado em resolver o problema da modernidade, isto é, de articular ator e sistema, sendo que no seu caso a unidade de análise é focada nas instituições. Uma das principais questões de sua sociologia consiste em pensar a relação entre solidariedade social e instituições produtoras de confiança, como por exemplo, a escola. Na sociedade moderna, a escola é uma instituição capaz de articular o processo coletivo e a liberdade individual e, segundo Durkheim, a liberdade do indivíduo é formada na própria afirmação da coesão social. Daí que, na sociedade moderna, a realização individual depende do processo de integração e a escola é a principal agência de inculcação de valores sociais e de individuação. Exercitando uma comparação podemos dizer o seguinte: enquanto o indivíduo em Durkheim se emancipa pela coesão social, em Marx (sabendo da ressalva de que ele não usa essa unidade de análise, mas sim a classe social) podemos dizer que é a partir da perspectiva do conflito de classe, pois pelo conflito se alcançará uma sociedade sem classe e, portanto, livre das opressões nas quais o operariado está submetido.

Embora de maneira muito breve, estamos pensando a questão da relação entre indivíduo e sociedade de modo a situar o processo de socialização escolar 
nesse problema constitutivo das ciências sociais. Seguindo o raciocínio, com Durkheim entendemos que as normas, os costumes e as regras sociais são sagradas e externas ao indivíduo, enquanto com Weber esse conjunto é fundamentalmente apoiado na ação social, em que as condutas e os comportamentos individuais são centrais e estão em relação de reciprocidade com os outros atores individuais. Preocupada em enfatizar que os sentidos da ação exercem um papel fundamental, a sociologia de Weber encara o indivíduo na ação social e disso resulta que as estruturas sociais são compreendidas como estruturas de significado. Isto é, a proposta teórica weberiana entende que a ação social possui papel ativo no condicionamento e na transformação da sociedade. Esse entendimento é bastante claro em A Ética Protestante e o Espírito do Capitalismo (1985), onde argumenta magistralmente que o espírito do capitalismo [a crença protestante] precedeu o capitalismo moderno [o mercado e suas relações de produção]. Desse modo, contrariamente à Marx, Weber mostra que a ação social deve ser pensada de uma perspectiva plural, não apenas referida a uma única dimensão.

Nessa proposição weberiana da relação indivíduo e sociedade a questão escolar, apesar de não ser dominante em sua obra, aparece como um elemento que contribui para a estratificação social. Quer dizer, a socialização escolar confere um capital de diferenciação ao indivíduo que pode lhe proporcionar vantagens na sociedade. Nesse sentido, como em Marx e em Durkheim, pode servir também como critério de manutenção da ordem social.

Apontar essa discussão sobre indivíduo e sociedade nos três autores como preâmbulo se faz importante porque com ela é possível identificar um problema metodológico que vai permear toda a história do pensamento sociológico, em que duas perspectivas básicas são encontradas: a da morfologia social e a do ator. Isto é, por um lado, essa breve explanação sobre Marx, Durkheim e Weber não tem o objetivo de recuperar por completo a discussão sobre indivíduo e sociedade tal como foi colocada por eles, mas registrar aqui que esses autores clássicos das ciências sociais ao abordarem de forma distinta as mudanças e o funcionamento social condicionaram diferentes posturas metodológicas na história de nossa disciplina, verificadas na base de diversas correntes contemporâneas. A questão é 
que as perspectivas contemporâneas acerca de uma mesma temática, inclusive da socialização escolar, apoiam-se em estruturas metodológicas que, de certo modo, remete-nos aos autores supracitados. Como exemplo disso pode-se elencar três correntes: a funcionalista, cuja base está em Durkheim [e também em Comte]; a perspectiva do conflito, com referência à Marx; e a da sociologia compreensiva de Weber e seus desdobramentos com o interacionismo simbólico.

Essas correntes, segundo Giddens (2005), são trilhas que servem a muitos pesquisadores e permeiam boa parte das investigações de inúmeras questões que interessam a sociologia. Certamente, pode-se argumentar, e com toda razão, que o plano atual da sociologia não necessariamente organiza seus problemas e nem os analisa de acordo com esse formato, que cumpre apenas uma maneira de abordar o pensamento sociológico. O ponto valorizado aqui é que através dessas correntes há possibilidade de estabelecer diálogos com os grandes pensadores das Ciências Sociais. E é isso que se está enfatizando nesse primeiro momento.

Por outro lado, a escolha dessa abertura tem a ver com o seguinte. É claro que o problema da relação entre indivíduo e sociedade foi resolvido antes da primeira metade do século XX, no entanto essa relação é contínua e sua extensão nos processos de mudanças segue interessando à teoria social. Isto é, embora indivíduo e sociedade se situem numa mesma rede de interconexões de recíproca formação, é preciso sempre problematizar como ocorre essa interdependência nas instituições socializadoras. Esse é um plano teórico central na análise dos episódios, que serão expostos no capítulo do recreio. Desse modo, parece ser importante saber como essa interdependência se configura ou como se dão as conexões atuais, ou formas comunicativas, entre indivíduo e instituição social, em outras palavras, no que consiste o processo de socialização, particularmente a socialização escolar. Atendendo estritamente a uma organização do raciocínio, a linha de investigação desse problema está ancorada em duas dimensões: a primeira trata de uma concepção mais sistêmica ou institucionalista, a segunda aborda uma perspectiva de valoração do sujeito e das interações.

Portanto, dentro do debate da relação indivíduo e sociedade, pretende-se contribuir para uma reflexão relativa à socialização e, de modo privilegiado, a 
socialização escolar a fim de termos mais subsídios para pensarmos as tensões que permeiam a relação entre indivíduo e instituição no recreio. Apesar de ser uma articulação exploratória, configurando-se como um processo de aprendizagem, acredita-se que mobilizando essa reflexão neste primeiro capítulo podemos colaborar para a compreensão de que o espaço escolar pode servir de lugar privilegiado para acessar a complexa trama entre as experiências individuais e as performances institucionais, que dizem respeito a um tipo específico de relação entre escola e sociedade. Isto é, pelo modo como a socialização se realiza pode-se acessar o modelo de sociedade existente.

\subsection{Sistema e consenso social ou a condição do indivíduo em face às estruturas}

Nesta seção está presente um esforço de organizar uma breve articulação sobre o processo de socialização que concebe maior autonomia à estrutura social. Nela, sempre que possível, serão privilegiados os trabalhos que pensaram a relação indivíduo e sociedade via instituição escolar. Ao longo da apresentação será possível perceber que a teoria aqui mobilizada enfatiza as propriedades estruturais da vida social, e uma autonomia relativa do indivíduo, frequentemente associada a uma ordenação que, em suas diversas variações, exerce eficazmente o controle social.

Começo por falar da educação em Durkheim porque, entre os pais fundadores das ciências sociais aqui mobilizados, foi o que mais pensou a questão da escola na sociedade moderna, contudo, mais à frente a perspectiva marxista da educação aparece para enfatizar a reprodução do sistema de poder pela 
socialização escolar ${ }^{5}$. Durkheim elaborou muitas reflexões sobre o papel da educação que para ele é algo fundamentalmente social, pois se trata de um fenômeno da sociedade. É com base na pergunta "qual é a função da educação?" que ele vai assinalar a proposta da sociedade moderna de articular uma base comum com a especialização individual. Segundo Durkheim (2011), é através da educação que os indivíduos são socializados para diferentes funções e atuação na sociedade, e essa diversidade de formações para os meios sociais, como a diversidade de profissões, não representa uma coleção de indivíduos fragmentada a ponto de por em risco a unidade da sociedade. Pelo contrário, embora forme uma diversidade na sociedade moderna, o poder da instituição escolar é firme na afirmação dos valores comuns que confere integração e coesão social. Para Durkheim, na sociedade moderna, a escola não tem apenas a finalidade de inculcar valores comuns, mas também de atender ao processo que exige uma divisão de papeis sociais, formando sujeitos para diferentes atividades produtivas, qualificações individuais que respondam às demandas da estrutura social daquele tempo. Nesse sentido, a escola está a serviço das próprias necessidades e finalidades do projeto de sociedade a que pertence.

Essa concepção sociológica da educação é, segundo ele, uma resposta à concepção moralista da filosofia da educação, como a de Kant, segundo a qual a educação deveria ser capaz de desenvolver todas as capacidades do homem de modo que o tornasse um indivíduo dotado de perfeição. Em sua crítica a Kant, que define o conceito de educação com base em concepção normativa, Durkheim afirma que um dos objetivos da educação é o de conseguir uma disposição social harmônica que tem a ver com as reais necessidades de sobrevivência de cada sociedade. Durkheim, então, propõe um ponto de partida que, diferentemente de Kant, não estipula o que a educação deve ser, exercício que encontra uma diversidade de concepções impossível de ser realizada socialmente, mas o que ela

\footnotetext{
${ }^{5}$ Dias (1987:35) afirma que embora Durkheim "tenha se dedicado, como é patente, com a mesma intensidade, à Educação e à Sociologia, o certo é que os livros fundamentais de teoria, pesquisa pioneira e metodologia obscurecem o restante da produção intelectual durkheimiana, inclusive na área educacional. Pela ordem cronológica, estas são as obras consideradas mais relevantes, ressaltando-se que os demais livros são quase todos póstumos: De la division du travail social (1893); Les règles de la méthode sociologique (1895); Le suicide (1887) e Les formes élementaires de 1 avie religieuse (1912)".
} 
efetivamente é em cada sociedade. A passagem a seguir traz a tonalidade dessa crítica:

Este próprio postulado, aparentemente incontestável, repousa sobre um erro de ordem mais geral. Se começarmos a nos perguntar assim qual deve ser a educação ideal, abstração feita de toda condição de tempo e lugar, isto significa que admitimos de modo implícito que um sistema de educação não é, por si mesmo, nem um pouco real (DURKHEIM, 2011: 47).

Essa crítica de Durkheim remetida à concepção moralista é fundamentada com a importância dos costumes e tradições de uma sociedade, cuja influência, para ele, é central na vida das pessoas e isso impede de se pensar em educar as crianças conforme nosso ideal de educação. Durkheim (2011) assinala que a história mostra a existência de diversos reguladores da educação, como os valores sociais, e não podemos deixar de considerá-los na formulação de seu significado. Ora, "quando se estuda historicamente a maneira como os sistemas de educação se formaram e se desenvolveram, percebe-se que eles sempre dependeram da religião, da organização política, do grau de desenvolvimento das ciências, do estado da indústria, etc." (p. 48) de tal modo que não é possível criar, construir, transformar ou estabelecer que a educação tenha certos fins sem observar as realidades existentes.

Portanto, a posição de Durkheim é a de quem se recusa a compreender o processo de socialização escolar a partir de normatividades ou de concepções abstratas que se mostrem distantes da vida social. É um duplo movimento em que, ao mesmo tempo, a sociedade inspira a concepção de educação e a ação socializadora a ser desenvolvida pela escola. De outro modo, a educação responde a necessidades específicas e deve ser realizada a partir do contato entre gerações, adultos agindo sobre crianças e jovens. Mas esse contato não é desprovido de sentidos, não se realiza no ar e nem como se quer. Então, qual é a natureza dessa ação?

Primeiro, importa dizer que todo sistema educacional, em qualquer sociedade, é, ao mesmo tempo, singular e múltiplo. É singular porque compartilha um conjunto de elementos comuns para a convivência e interação entre as pessoas e, por outro lado, é múltiplo por oferecer educações específicas. Essas 
especificidades são representadas por papeis socais definidos com base, por exemplo, na classe social, no habitat ou mesmo em profissões. Embora haja uma base comum que estabeleça ideias e práticas consensuais, na sociedade moderna a educação jamais será uniforme, pois as crianças são submetidas a especializações que exigem distintas faculdades. Conforme Durkheim:

De fato, cada profissão constitui um meio sui generis que demanda aptidões e conhecimentos específicos, um meio no qual predominam certas ideias, usos e maneiras de ver as coisas; e, já que a criança deve estar preparada com vistas à função que será levada a cumprir, a educação, a partir de determinada idade, não pode mais continuar a mesma para todos os sujeitos aos quais ela se aplicar. É por isso que, em todos os países civilizados, ela tende a cada vez mais a se diversificar e se especializar, e esta especialização, a se tornar cada vez mais precoce (DURKHEIM, 2011: 51).

Essa diversidade de especificações vai sendo estabelecida segundo o ideal de homem de cada sociedade, e a educação cumpre um papel crucial na introjeção desse ideal, com certos estados físicos e mentais definidos ao longo da vida social. A natureza da ação educativa é inculcar nas gerações mais novas o ideal, ao mesmo tempo, único e diverso. Isto é, nas crianças deve ser desenvolvida uma unicidade de estados físicos e mentais comuns a todos os membros e, concomitantemente, especificidades correspondentes ao grupo social de origem.

Para Durkheim não há cooperação sem especificações e é essa (cooperação-especificação) articulação que une consciência coletiva e consciência individual na sociedade moderna. Esse é o desafio das gerações adultas, conforme diz a passagem a seguir (2011: 53/54):

A educação é a ação exercida pelas gerações adultas sobre aquelas que ainda não estão maturas para a vida social. Ela tem como objetivo suscitar e desenvolver na criança um certo número de estados físicos, intelectuais e morais exigidos tanto pelo conjunto da sociedade política quanto pelo meio específico ao qual ela está destinada em particular.

Durkheim (2011) mostra que a existência da sociedade depende exclusivamente do poder de instituições como a escola, família e igreja. Com efeito, é preciso atentar para a função específica conferida à escola. É certo que essas instituições têm o poder de educar para a vida em sociedade, mas, no contexto moderno, família e igreja são instituições tradicionais e a escola se afirma enquanto referência no desenvolvimento de uma consciência coletiva. 
Assim, o trabalho de Durkheim é uma referência para afirmar que, embora família e igreja também eduquem, a escola é a instituição moderna capaz de exercer o duplo movimento de consolidar, por um lado, a homogeneidade exigida pela vida coletiva e, por outro, a diversificação que torna o indivíduo autônomo.

Durkheim (2011), então, concebe uma importância singular ao processo educacional e isso fica ainda mais claro quando o sociólogo afirma que a criança entra na vida apenas com a sua natureza individual, frequentemente marcada por egoísmo e comportamentos associais, e, desse modo, a cada nova geração, a "sociedade se encontra em presença de uma tábula quase rasa sobre a qual ela deve construir novamente" (p. 55) sua virtualidade. A verdade é que a sociedade se (re)institui através da criação de um novo homem. Dito de outro modo, com o trabalho das instituições sociais, a criança torna-se um ser capaz de levar uma vida moral e social e, nesse entendimento, Durkheim confere centralidade ao papel desenvolvido pela instituição escolar. Nesses termos, socialização escolar é transmissão de um conjunto de práticas e valores que têm a ver com a resolução das próprias necessidades da sociedade. Ao lado da família e da igreja, a escola, na forma moderna, é via de transmissão por excelência.

É um processo de reprodução da sociedade. A vida social depende da inculcação nos indivíduos de seus elementos mais essenciais. E o próprio indivíduo adquire para si o desejo de ser socializado, já que a sua individualidade está em ser aceito e integrado socialmente. Para Durkheim, as próprias qualidades buscadas pelo indivíduo, bem como a prescrição de sua realização, são forjadas na e pela sociedade. Daí a sua submissão àquilo que pode parecer "uma insuportável tirania”, conforme diz Durkheim (2011: 58).

Enquanto mostrávamos a sociedade modelando os indivíduos de acordo com as suas necessidades, podia parecer que eles sofriam assim uma insuportável tirania. Porém, na realidade, eles próprios têm interesse nesta submissão, pois o novo ser que a ação coletiva edifica em cada um de nós através da educação representa o que há de melhor em nós, ou seja, o que há de propriamente humano em nós. De fato, o homem só é homem porque vive em sociedade.

Moral e sociedade são termos que se articulam perfeitamente em Durkheim. Na verdade, ele enfatiza que a moralidade resulta da vida coletiva, 
tanto que um homem sem os elementos constituídos pela sociedade seria reduzido a um ser pré-moral. Diante disso o problema do antagonismo entre a sociedade e o indivíduo é resolvido, uma vez que, em vez de oposição, há implicações de um em relação ao outro. Isto é, "ao querer a sociedade, o indivíduo quer a si mesmo". Mas isso não é dado naturalmente. Portanto, como pode ser eficaz? A educação escolar é a responsável por fazer alcançar os grandes resultados, para tanto, precisa agir de modo rígido. Dessa maneira, "pode-se dizer desde já que a educação deve ser, em sua essência, uma questão de autoridade" (DURKHEIM, 2011: 70), que se traduz na atuação do professor. Mas essa autoridade não se confunde com violência ou repressão, trata-se de uma qualidade moral que corresponde ao papel desempenhado pelo professor, qual seja, o de porta-voz da sociedade.

Com esse processo de socialização é possível entender que, em Durkheim, a relação indivíduo e sociedade está ancorada na forte predominância desta unidade, no entanto não se trata de um confinamento do indivíduo. Nela, a educação é o motor do processo socializador e, na sociedade moderna, a escola é concebida como a principal agência de reprodução dos valores comuns em face das ideias particulares inscritas na vida social - mas, não esqueçamos que outras instituições sociais também têm a função de educar. A coesão e a consciência coletiva são formas sociais utilizadas para afirmar que a sociedade não é uma coleção de indivíduos, mas um conjunto socializado pelas instituições, em especial a escolar, que corresponde a um modelo específico de sociedade. Em virtude dessa finalidade a educação escolar atua no indivíduo e, desse modo, a escola se situa a serviço da sociedade. É nela que o indivíduo vai encontrar a referência com a qual dará sequência à configuração social estabelecida, mas também forjará a mudança quando o próprio percurso social exigir. No limite, a escola é que forja a sociedade e, esta, o indivíduo; a socialização escolar serve para dar vida à sociedade, reproduzindo-a e também a transformando, pois, em Durkheim, a escola, junto com outras instituições, renova a sociedade e seus membros. Desse modo, Durkheim identifica na escola atribuições que, na sociedade tradicional, não se diferenciavam de instituições como as igrejas e a família. 
Essa sociologia do processo de socialização não está referida a uma reflexão que tem por base uma defesa da sociedade sem autonomia individual, como à primeira vista somos levados a concluir. $\mathrm{O}$ fato é que Durkheim entendia o indivíduo na sociedade moderna de uma maneira bem específica. Sobre esse aspecto da obra de Durkheim, Anthony Giddens (1998) tem uma interessante contribuição ao discutir a noção de "individualismo", e, embora de maneira muito breve, essa reflexão parece ser importante aqui para melhor compreendermos a condição do indivíduo frente à sociedade no pensamento de Durkheim.

Conforme Giddens (1998), em "A divisão social do trabalho" Durkheim assinala que o indivíduo nas sociedades tradicionais compartilha traços similares com outros membros e adquire uma autonomia profundamente limitada, pois possui uma consciência coletiva forjada nos laços que o ligavam a seu grupo. Durkheim denominou esse condicionamento de solidariedade mecânica. Nas sociedades modernas a consciência coletiva é modificada e sua moralidade se realiza, sobretudo, via laços com grupos formados a partir da especialização ocupacional - uma marca das novas formas de trabalho. Nessa "solidariedade orgânica", como Durkheim a denominou, o indivíduo adquiriu maior autonomia porque a vida já não poderia ser desenvolvida dentro das formas tradicionais. A autonomia individual é concebida nas formas especializadas da ocupação. Desse modo, seguindo a leitura de Giddens (1998), assim como as demandas individuais não estão naturalmente contidas, como previa a filosofia utilitarista, a autonomia é socialmente criada.

Anthony Giddens (1998) afirma que dois problemas são encontrados em interpretações desatentas à proposição sociológica durkheimiana. O primeiro diz sobre uma luta incansável à consecução da ordem e o segundo fala de uma disciplina moral fortemente autoritária. Ordem e disciplina são termos sugestivos para uma compreensão de Durkheim baseada, estritamente, na oposição integração e desintegração. É claro que ele atribuiu uma importância à coesão na sociedade, uma ordem moral distinta da forma tradicional, e à anomia, que, quando instalada, nesse caso a sociedade usará de sua força para controla-la. Entretanto, segundo Giddens (1998), a questão que Durkheim procurou tratar foi a das profundas transformações sociais que impuseram uma nova configuração, 
especialmente referida a uma maior individuação e à fragmentação da moral fixa. Giddens diz que isso levou Durkheim a problematizar o "individualismo" na sociedade moderna, defendendo uma condição distinta de individuação, termo mais próximo a um egoísmo cuja referência teórica é a perspectiva utilitarista. O ponto de Durkheim é que, para ele, existe uma moralidade anterior a do indivíduo, qual seja: a da sociedade. Conforme Giddens (1998), dessa acepção emerge o seu individualismo moral, em que o indivíduo não é somente moldado pela sociedade, mas a sua própria conduta ativa é "articulada pelas normas morais internalizadas" (GIDDENS, 1998: 161).

Então, com base no que foi exposto anteriormente e também na leitura de Giddens (1988), compreendemos que para Durkheim a individualidade está relacionada à sociedade e, nesse sentido, a liberdade individual tem a ver com o processo de integração social. Na sociedade moderna essa tarefa é conferida à instituição escolar. Assim como em Durkheim, Karl Mannheim também confere protagonismo à educação escolar no transcurso da vida social.

A educação como um mecanismo de coesão e baliza da sociedade é reforçada por Karl Mannheim (1951) que, em sua análise, entende a educação escolar, a política e os meios de comunicação como "técnicas sociais". Ante de trazer a definição da educação como técnica social, importa contextualizar o período no qual Dukheim e Mannheim estão construindo suas interpretações sobre o papel da escola e, consequentemente, suas defesas sobre a finalidade da socialização escolar. Enquanto as reflexões durkheimianas sobre a educação escolar se situam no início do século XX, em que a vida social é marcada pelo aprofundamento da divisão social do trabalho, o entendimento de Karl Mannheim a respeito dessa questão é datado no período do pós-segunda guerra. Articular a concepção de Mannheim a de Dukheim neste trabalho se justifica pelo fato de que esse autor, além de dar centralidade à função escolar, apresenta uma concepção de escola que tem a ver com a perspectiva de Durkheim, inclusive na questão da mudança social.

A educação como técnica social, segundo Karl Mannheim (1951), referese a um método capaz de dinamizar a sociedade pela ação e comportamento 
humano especializado, mas também segundo o qual se realiza a coesão e, no limite, o controle social. Essa técnica inerente à educação escolar realiza a socialização do indivíduo com os padrões de interação e organização da sociedade, como também lhe confere habilidades para atuar em diferentes contextos sociais, sejam eles com princípios democráticos ou autoritários. Quer dizer, a educação escolar é uma técnica maleável segundo as doutrinas de cada sociedade. Nesse sentido, assim como Durkheim afirmou que a educação está a serviço de um ideal de homem, Mannheim assinala que essa técnica social não só condiciona o ajustamento dos indivíduos à vida social, como também está "destinada à criação do tipo desejado de cidadão" (MANNHEIM, 1951: 89) e, consequentemente, de sociedade. Portanto, conforme lembra bem Saviani (1991), a educação compreendida como uma técnica pode ser "vista como solução para determinados problemas de caráter social" por ser um procedimento da sociedade "para responder a determinados problemas que ela enfrenta" (SAVIANI, 1991: 43).

Tanto para Durkheim como para Mannheim, a educação não está referida a um homem em abstrato, mas àquele que é moldado na/pela/para a sociedade. A sociedade situada em um contexto específico é que demandará objetivos educacionais em afinidade com um ideal de homem, estabelecendo códigos, normas e expressões de ajustamento individual ao grupo social a que pertence. Como indica a passagem abaixo,

Esses objetivos educacionais, em seu contexto social, são transmitidos à nova geração, juntamente com as técnicas educacionais vigentes. As técnicas educacionais, por sua vez, não se desenvolvem isoladamente, mas sempre como parte do desenvolvimento geral das técnicas sociais. Assim, a educação apenas será corretamente compreendida se a consideramos como uma das técnicas que influenciam o comportamento humano e como um meio de controle social. A menor mudança nessas técnicas e controles mais gerais reflete-se na educação em sentido restrito - ou seja, a processada no interior da escola (MANNHEIM, 1951: 90).

A socialização escolar reage às possíveis tensões que podem existir entre a sociedade e o indivíduo (ou grupos sociais), e sua ação claramente é compreendida, conforme reflexão de Mannheim, como uma técnica à disposição da sociedade para exercer o papel de formar as gerações que possam atender as necessidades da ordem social. Interessa notar que Durkheim e Mannheim se 
interconectam em alguns pontos, principalmente, no que diz respeito à socialização escolar como um importante meio de realizar a integração do indivíduo aos grupos sociais. A educação, portanto, é uma importante técnica pela qual a sociedade deve realizar o desafio de manter a coesão da sociedade.

No contexto que precede os movimentos sociais da década de 1960, Mannheim (1954) analisa os grupos sociais e chega a afirmar que a sociedade, em momento de necessidade, deverá mesmo organizá-los porque não se trata mais de uma sociedade estática, que não sofre quase nenhuma mutação. $\mathrm{Na}$ "sociedade dinâmica", grupos sociais como a juventude são entendidos por Mannheim como "reservas latentes", prontas para servir à sociedade, mas cabe às técnicas sociais realizarem a integração dessas reservas a uma função na sociedade. Assim como em Durkheim, Mannheim entende que o trabalho de socialização das novas gerações consiste em produzir solidariedade social, já que a finalidade é a integração desses grupos na sociedade.

\begin{abstract}
Resumindo os resultados de nossa análise geral: a juventude é uma grande parcela importante daquelas reservas latentes que se acham presentes em toda sociedade. Depende da estrutura social o fato de essas reservas - e também quais dentre elas - serem ou não mobilizadas e integradas numa função. $\mathrm{O}$ fator especial, que torna os adolescentes o mais importante trunfo para a nova orientação societária geral, é que eles ou elas não tomam a ordem estabelecida como indiscutível e não têm interesses comprometidos, seja com sua ordem econômica, seja com sua ordem espiritual. Finalmente, as sociedades tradicionalistas, estáticas ou lentamente mutáveis, operam sem a mobilização e integração desses recursos. Elas serão, mesmo, hábeis na supressão dessas potencialidades, enquanto que uma sociedade dinâmica terá, mais cedo ou mais tarde, de despertar esses recursos latentes e inclusive, em muitos caos, organizá-los (MANNHEIM, 1954: 97).
\end{abstract}

Mannheim e Durkheim pensam a educação escolar como campo privilegiado para a ordem e integração da sociedade. Mas, se quisermos explorar a passagem acima, em um pequeno exercício analítico, podemos estabelecer um ponto de diferenciação entre esses autores. Embora possa ser controvertido, mesmo porque isso não está claro, o papel educacional em Mannheim apresenta maiores possibilidades das novas gerações dinamizarem a sociedade por não ter comprometimento com qualquer grupo social concreto. Então, se em Durkheim quase não se lê o papel da educação escolar como edifício para a construção de novas moralidades, isto é, se Durkheim é mais enfático em conformar os 
comportamentos individuais às estruturas sociais, um condicionamento estabelecido em favor da ordem moral existente, Mannheim dá mais possibilidade aos indivíduos na construção de ordenações que não necessariamente estejam relacionadas aos valores consolidados ou à "ordem espiritual" estabelecida. Essa "abertura" aparece na capacidade da juventude de dinamizar a vida social. No entanto, esse ponto precisaria de mais investigação para se afirmar como uma importante diferenciação: quer dizer, não é possível afirmar com tanta força que a educação escolar em Durkhiem reproduz consenso e valores, ao passo que em Mannheim é ponto de partida para mudanças na realidade. O que podemos afirmar é que, embora situados em momentos diferentes do século XX, Durkheim e Mannheim enxergam a educação escolar assumindo um protagonismo cada vez maior na ordem social moderna. Ambos, portanto, identificam a necessidade da escola para a vitalidade da sociedade.

Uma importante chave analítica do processo de socialização escolar nesse eixo que pensa o consenso social, conforme vimos com Durkheim e Mannheim, é a perspectiva crítica em torno da ordem social estabelecida. Essa tarefa ficou a cargo das leituras que enfatizaram as relações de poder na sociedade e o conflito entre as classes sociais, bem como denunciaram a função socializadora da escola na sociedade moderna. Assim como os autores vistos agora pouco, que concebem preponderância às estruturas sociais, a perspectiva de análise crítica dos processos socializadores vai enfatizar a sociedade como principal unidade de análise, só que na sua forma de classes sociais. O fato é que, de um lado, a autonomia do indivíduo é relativa frente à sociedade, como vimos com a apresentação de Durkheim e Mannheim; de outro, na sociologia do conflito, as classes sociais dominadas são coagidas pela estrutura dominante. Em ambas, no entanto, a capacidade de mudança da realidade objetiva aparece como uma possibilidade de realização fruto do processo de socialização escolar.

Apesar de Karl Marx não ter elaborado obras que deem atenção exclusiva ao tema da educação, a ponto de nos permitir apresentar sua concepção de socialização escolar, é possível falar de uma compreensão dos sistemas de ensino a partir de sua análise da dinâmica socioeconômica que configura a sociedade moderna. A sociologia de Marx, de modo especial, é aquela que intensamente 
descreve a dinâmica da luta de classes e das relações de poder com base no processo histórico de desenvolvimento da realidade social, em que o capitalismo em sua forma de atividades produtivas (caracterizadas, especialmente, pela dicotomia capital e trabalho) e de advento da propriedade privada estabelece os modos de convivência entre os homens. Do ponto de vista epistemológico esse processo pode ser entendido como uma arquitetura na qual as relações sociais e a formação do sujeito se dão dialeticamente com a condição do ambiente em que vive. Mais especificamente esse entendimento foi denominado de materialismo histórico, ou tese materialista da história. Como dizem Marx e Engels (2007: 94), referindo-se aos jovens hegelianos, o ponto dessa tese é que "totalmente ao contrário da filosofia alemã, que desce do céu à terra", considera-se que "não é a consciência que determina a vida [real], mas a vida [real] que determina a consciência”.

Isto significa, portanto, que os homens estão em relação de dependência com as condições materiais da existência, mas numa relação dialética entre indivíduo e contexto social em que vive. A respeito disso, nas Teses sobre Feuerbach, Marx diz o seguinte:

\begin{abstract}
A teoria materialista de que os homens são produtos das circunstâncias e da educação e de que, portanto, homens modificados são produtos de circunstâncias diferentes e de educação modificada esquece que as circunstâncias são modificadas precisamente pelos homens e que o próprio educador precisa ser educado. Leva, pois, forçosamente, à divisão da sociedade em duas partes, uma das quais se sobrepõe à sociedade. A coincidência da modificação das circunstâncias e da atividade humana só pode ser apreendida e racionalmente compreendida como prática transformadora (MARX, 1845: III).
\end{abstract}

Desse fragmento das Teses de Feuerbach podemos pensar duas questões importantes para a compreensão, digamos assim, da relação entre escola e sociedade na perspectiva de Marx. A primeira é que a instituição escolar compreende práticas permeadas pelas circunstâncias do ambiente social, cuja base está na ideologia da classe dominante; a segunda diz sobre a possibilidade de a classe operária transformar os termos dessas circunstâncias.

Quanto à primeira questão, a formulação de Marx permite compreender que a classe dominante dos meios de produção é uma potência que dispõe de um 
controle forjado na aquisição de bens materiais e, ideologicamente, propaga uma visão de mundo e estabelece as regras de convívio social. Nesse sentido, enquanto pertencente à superestrutura, a escola joga a favor da sustentação da hierarquia social ao desenvolver uma perspectiva socializadora da classe dominante, em que consiste o domínio da cultura burguesa sobre o proletariado. Nas palavras de Marx e Engels (2007),

\begin{abstract}
A classe que tem à sua disposição os meios de produção material dispõe também dos meios de produção espiritual, de modo que a ela estão submetidos aproximadamente ao mesmo tempo os pensamentos daqueles aos quais faltam os meios da produção espiritual. (...) Os indivíduos que compõem a classe dominante possuem, entre outras coisas, também consciência e, por isso, pensam; na medida em que dominam como classe e determinam todo o âmbito de uma época histórica, é evidente que eles o fazem em toda a sua extensão, portanto, entre outras coisas, que eles dominam também como pensadores, como produtores de ideias, que regulam a produção e a distribuição das ideias de seu tempo; e, por conseguinte, que suas ideias são as ideias dominantes da época (MARX \& ENGELS, 2007: 47).
\end{abstract}

Em relação à segunda questão, da possibilidade de transformação das circunstâncias, o que está presente é o desafio de conquistar uma consciência com a qual será possível construir uma nova ordem social. No entanto, como adquirir um nível de consciência capaz de gerar uma transformação da realidade social se a condição na qual se encontra o proletário é a de subordinação? Uma primeira lembrança a ser feita a respeito desse ponto é a não passividade do indivíduo, embora em situação de subordinação, na arquitetura de poder da classe burguesa. Além disso, como está posto no Manifesto Comunista (1997), Marx e Engels afirmam a importância da burguesia no processo de politização desse movimento que dará lugar a uma transformação - esse ponto é simbolicamente revelado na célebre frase "a burguesia produz, sobretudo, seus próprios coveiros".

Com Antonio Gramsci podemos falar sobre esses dois pontos sem nos afastar muito da proposta deste capítulo. Em Gramsci e a Escola (1988), Luna Mochcovitch mostra como a burguesia exerceu a função de consolidar a ideologia da liberdade, igualdade e fraternidade ao se colocar na história contra a antiga ordem feudal a fim de instaurar uma nova realidade social. Diz a autora:

Formulado contra a ordem feudal - que se articulava em torno dos privilégios arbitrários de uma classe dominante fechada, do despotismo 
de governantes, e da miséria e ignorância das massas - o ideário da burguesia expressou-se de início no pensamento dos filósofos do racionalismo e do iluminismo e consubstanciou-se finalmente no projeto político e ideológico republicano e constitucional. Liberdade, igualdade e fraternidade são a negação da ordem feudal e as palavras de ordem que unem as massas em torno da burguesia para a destruição desta mesma ordem. Mas também são compromissos para a fundação da ordem que se instaura (MOCHCOVITCH, 1988: 45/46).

Segundo Mochcovitch (1988), esse ideário mobilizado pela burguesia é elemento fundante da ordem que, inclusive, vai modelar as funções do Estado. No discurso hegemônico da classe burguesa a "promessa de igualdade", por um lado, submete o Estado a uma moralidade de prover o acesso à escola como um direito, por outro, é central na luta dos movimentos dos trabalhadores pela afirmação desse direito e ampliação da cidadania. Desse modo, conforme a autora lendo Gramsci, a escola se torna central na socialização dos subalternos a fim de elevar a cultura das "massas para adequá-las à modernização e ao crescimento das forças produtivas da sociedade capitalista", mas também encarada como uma possibilidade para a mudança. Pois, passar pela escola não consiste em apenas um processo de submissão passiva à arquitetura de poder sociocultural da classe dominante, o próprio subalterno se apropria de uma consciência política que forja a possibilidade de mudar as circunstâncias dadas. O fato é que o entendimento de Gramsci é o de que "o acesso aos códigos dominantes dos quais a alfabetização é o primeiro passo, o conhecimento de direitos e deveres, e a capacidade de exigilos podem educar também para a transformação da ordem e não apenas para o conformismo e a adesão" (MOCHCOVITH, 1988: 64/65).

Pois bem, apesar dessa perspectiva se encontrar numa chave bem diferente da presente em Durkheim, pode-se dizer que uma convergência está no fato de a escola ter a capacidade de emancipar: em Durkheim a escola não é apenas um recurso à manutenção da ordem, pode mesmo servir à mudança social - desde que se forje uma escola para esse tipo de intervenção, isto é, desde que a perspectiva de mudança esteja no seio da sociedade; em Gramsci, apesar de a escola ser uma instituição de dominação, há possibilidade de os subalternos adquirirem a consciência e, a partir disso, modificarem a estrutura hegemônica estabelecida pela classe com poder. Portanto, tanto na perspectiva durkheimiana, como na 
leitura crítica de Gramsci o que está em jogo não é apenas uma questão de reprodução social.

Essa capacidade relativa da escola proporcionar a mudança social aparece também na sociologia crítica de Pierre Bourdieu, que enfatiza a dominação a partir de elementos socioestruturais implicados no trabalho escolar. Efetivamente, o que são os elementos socioestruturais? Anthony Giddens (1989) afirma que podem ser definidos da seguinte maneira: "a fixação de limites à gama de opções a que um ator, ou pluralidade de atores, tem acesso numa dada circunstância ou tipo de circunstâncias" (GIDDENS, 1989: 144). Trata-se, portanto, de uma questão de acesso a um conjunto plural de opções na vida que ampliam ou limitam as experiências individuais ou, para ser fiel à matriz analítica de Bourdieu, das classes.

No desenrolar dos anos de 1960, Pierre Bourdieu surge com uma proposta que pretende dar conta, teórica e empiricamente, dos problemas que imputavam à sociologia uma crise institucional. O seu esforço foi tão magistral que resultou em um ordenamento analítico servindo de base para o desvendamento dos elementos socioculturais de dominação. Ao investigar especificamente o fenômeno das desigualdades sociais, Pierre Bourdieu procura responder questões de como as sociedades reproduzem os sistemas de dominação e em que pilares determinados grupos sociais estabelecem os sistemas de classificações, categorias e representações da sociedade equacionadas como base de referência para os outros grupos de indivíduos. Para Nogueira e Catini (1998), os resultados das pesquisas de Bourdieu, frutos de profundos estudos sobre a tensão entre as classes sociais, assinalam para uma hierarquização escolar correspondente à estrutura social, uma vez que a instituição escolar é classificada como uma agência valorativa da cultura dominante. Diante disso a relação entre classes é uma relação de poder, e a escola chancela essa assertiva nos desempenhos escolares e destinos sociais.

O aprofundamento desse argumento é chancelado por Bourdieu e Passeron (1975) ao enfatizar a materialidade da relação entre desempenho escolar e origem social, tratando os resultados finais da escola como expressões das diferenças sociais iniciais dos alunos. Nessa análise do sistema escolar e sua socialização a 
questão familiar aparece como uma elemento central. Pois, para Bourdieu e Passeron a habilidade de obter uma boa performance na instituição escolar não depende de uma condição exclusiva da ação do sujeito, mas fruto de uma correlação de fatores externos e escolhas individuais que estão perfeitamente atreladas às "formas anteriores de trabalho pedagógico", como o habitus familiar. A respeito disso vale ler o que dizem os autores:

A análise das variações da eficácia da ação de inculcação que se realiza principalmente em e pela relação de comunicação conduz por conseguinte ao princípio primeiro das desigualdades do êxito escolar dos alunos procedentes das diferentes classes sociais: com efeito pode se colocar, por hipótese, que o grau de produtividade específica de todo trabalho pedagógico que não seja o trabalho pedagógico realizado pela família é função da distância que separa o habitus que ele tende a inculcar (sob a relação considerada aqui, o domínio erudito da língua erudita) do habitus que foi inculcado por todas as formas anteriores de trabalho pedagógico e, ao termo da regressão, pela família (isto é, a domínio prático da língua materna) (BOURDIEU \& PASSERON, 1975: 81).

Até aqui, a nossa problematização mais geral permite extrair ferramentas de análise das questões que estão presentes na prática escolar, conforme veremos com o capítulo dos episódios de recreio. Como sabemos, uma dimensão importante do que acontece na escola diz respeito à comunicação entre aluno e professor, que pode ser mais ou menos bem sucedida. Com base na perspectiva crítica, entendemos que a relação da escola com a classe popular é marcada por uma comunicação bastante truncada, por tratar-se de uma distância que tem a ver com o que é valorizado pela instituição escolar [elementos da cultura erudita] e o que é dominado pelos filhos de famílias populares [elementos que fogem ao domínio da cultura valorizada pela escola].

Essa perspectiva, portanto, trata de articular desempenho educacional e origens sociais como forma de criticar a socialização e a integração da classe popular na sociedade contemporânea. A preocupação mais importante dessa análise é fazer o registro de que o fracasso na escola não consiste em uma responsabilidade do aluno, mas em uma questão de capital cultural. Vale dizer que Pierre Bourdieu, em toda sua trajetória intelectual, procurou mostrar como a 
escola contribui para a reprodução do capital cultural e, de forma mais geral, para a reprodução da estrutura de poder no espaço social. Ou seja, para ele as operações escolares autorizam, legitimam e garantem os privilégios dos detentores de capitais. Desse modo, a escola, ao lado da família, é uma das principais instituições responsáveis pela manutenção e perpetuação dos privilégios de certos grupos sociais (Bourdieu, 1996). Essa leitura reprodutivista, paradoxalmente, não é completamente determinista, principalmente porque não desconsidera as possibilidades de mudanças da realidade social pela escolarização. A verdade é que Bourdieu sempre acreditou nas possibilidades de mudanças, pois apesar de serem pequenas, elas existem.

No raciocínio teórico de Bourdieu e Passeron (1975) as estruturas têm um papel de produzir subjetividade nos indivíduos e estes, com autonomia relativa através dos valores e crenças sociais, validam essas disposições duráveis e objetivadas. Trata-se, portanto, de um processo de "estruturação das estruturas estruturantes" que se traduz em uma profunda articulação entre as dimensões subjetivas e as objetivas da vida social. Essa compreensão traz consigo uma proposta teórico-metodológica, revelada especialmente no conceito de "habitus", de pensar o processo de socialização e suas redes de interações, compostas por conflitos e padrões comportamentais e institucionais, a partir de uma instância intermediária articulando tanto os aspectos estruturais como os dos sujeitos.

Basil Bernstein, antes de Pierre Bourdieu, também assinala que a escola possui sistemas simbólicos referidos à distribuição de poder e princípios de controle. Segundo Davies (2003), para Bernstein poder e controle são eixos analíticos que permitem classificar os agentes, discursos, práticas educacionais e sua correspondência com a disposição social. Através desses "eixos reguladores" é possível compreender o que subjaz às mensagens entre transmissor e receptor. De acordo com Davies (2003), as diferentes aquisições pedagógicas apontam "para arenas ideológicas de apropriação, patrocínio e criação, indicando a base social da aquisição diferencial" (p. 63). Ou seja, "as diferentes experiências de crianças no início da vida escolar, à medida que vão tomando consciência do que se espera delas, forneceram uma primeira ideia da assimilação/cumprimento de regras, processo em que o poder simbólico da família de classe média (...) se traduz na 
capacidade de reconhecimento de regras pela criança, com seus resultados favoráveis" (DAVIES, 2003: 67). Daí resulta uma equação em que os dispositivos escolares, através dos meios discursivos, são formas de perpetuação de poder e estabelecem representações ideológicas.

Essas sociologias da educação da segunda metade do século XX são feitas com diferentes enfoques, mas do ponto de vista dos processos socializadores dão ênfase a uma dinâmica que confere autonomia relativa ao sujeito, ou seja, são sociologias que permitem enxergar uma força que foge ao domínio individual ${ }^{6}$. Logo, a abertura para ação individual é bastante restringida. A convergência analítica entre essas sociologias existe, tanto que, por exemplo, conforme Davies (2003), Bernstein articula as formas de controle durkheimianas e os elementos de conflito que apontam para apropriações ideológicas de grupos sociais. Isso está presente na sua reflexão que enfatiza os sistemas simbólicos na escola como representantes de elementos de poder na sociedade. Pode-se dizer que Pierre Bourdieu e Jean-Claude Passeron (1975) estão nessa mesma estruturação teórica ao enfatizarem a lógica da reprodução do sistema de dominação. No mais, as abordagens apresentadas tendem a valorizar uma dimensão supraindividual presente nas condutas humanas e definidora da própria organização societária, ou seja, propriedades da estrutura social caracterizando a dinâmica da vida em sociedade.

\subsection{A afirmação do sujeito na unidade social: sujeitos intensificando a socialização escolar.}

Os estudos da socialização a partir da década de 1980 vão redescobrir Georg Simmel, Max Weber e todo um conjunto de trabalhos elaborados, posteriormente, por autores como Alfred Schütz, com suas reflexões sobre a fenomenologia, e G. H. Mead, da interação simbólica, bem como a abordagem de Peter Berger e Thomas Luckmann, que organizam uma visão do social com base

\footnotetext{
${ }^{6}$ É bom registrar que para uma análise mais completa e aprofundada da sociologia da educação da segunda metade do século XX seria necessário incorporar outros autores nessa seção, inclusive brasileiros.
} 
na perspectiva das pessoas que constroem o mundo humano (Dubar, 2005). Nascem daí novas concepções de compreensão da socialização, não mais definidas como aprendizado ou incorporação de valores sedimentados, mas como um processo dinamizado pelo sujeito. Trata-se de uma sociologia que valoriza a participação ativa do sujeito na construção e reconstrução dos contextos sociais e culturais.

Essas abordagens compõem um campo de análises fundadas em premissas categorizadas como ação, interação, experiência e meio, e forjam uma interpretação das manifestações e constituições sociais que entra em disputa com perspectivas que condicionam os comportamentos individuais às estruturas superdimensionadas, como é o caso da teoria estrutural-funcionalista, predominante até a década de 1970. Dubar (idem) assinala que essa sociologia, compreendida como um movimento de retorno do ator ${ }^{7}$, é fruto de novas contradições e incoerências advindas com as transformações sociais, políticas e culturais. Para ele, as transformações da segunda metade do século XX proporcionam novos sentidos para a socialização, desta vez não mais interpretada somente com base na teoria do habitus, como a presente em A Reprodução (1975) de Bourdieu e Passeron, ou mesmo pelas abordagens culturalistas; ao enfatizar uma ordem não mais claramente definida, a sociologia do ator intensifica a participação do sujeito na vida social a fim de gerar uma compreensão mais fiel ao contexto de uma sociedade em mudança. Nesse sentido, o próprio processo de socialização escolar é reinterpretado como um desafio que, de um lado, interpela mais a performance institucional, e de outro, no plano da teoria social, a reinterpretação exige outra formulação sociológica para melhor apreensão da capacidade da escola de socializar as crianças e adolescentes.

$\mathrm{Na}$ abordagem sociológica que exprime sólidas realidades coletivas, o ator individual é tecido dentro de um processo de absorção de normas e valores sociais que lhe concebe uma autonomia relativa para o desenvolvimento de um autocontrole capaz de corresponder a uma conduta esperada pela sociedade - ou

\footnotetext{
${ }^{7}$ É importante dizer que Dubar (2005) usa a noção de ator na mesma significação de sujeito. Aqui, como estamos preocupados em socialização escolar, não vamos estabelecer a distinção sociológica entre essas duas noções porque seria necessária uma investigação que desviaria o nosso foco.
} 
seja, para o seu bom funcionamento. Nessa perspectiva a socialização é entendida como um processo de integração das novas gerações com o compromisso de garantir coesão social. No entanto, o sentido de socialização vai ganhar complexidade com a afirmação do sujeito e interpelação da capacidade das instituições de realizar a integração numa sociedade que, cada vez mais, amplia os direitos sociais e é desafiada a construir um novo pacto.

A proposta de socialização que tem como centro a perspectiva do ator está no eixo oposto às abordagens que o entendem como um ser que deve incorporar regras, valores e estrutura de crenças sociais estabelecidas. Para Dubar (2005), esse conteúdo encontra forte respaldo nas teorias funcionais e culturais, nas quais os indivíduos são socializados com base na interiorização, palavra central que permeia toda a relação entre indivíduo e normas/disposições de uma sociedade, que faz deles uma extensão do social. O problema desses tipos de abordagens é que reduzem a socialização a uma forma de integração social ou cultural fundada em um "condicionamento inconsciente", cujo pressuposto básico, para as sociedades tradicionais, é a "unidade do mundo social" e, para as sociedades modernas e globalizadas, é a imposição da lógica de "maximização dos ganhos materiais ou simbólicos" (p. 97).

As transformações das sociedades têm problematizado a noção socializadora que admite o princípio unificador e, com efeito, a realidade social tida como integrada, certa, desprovida de uma interação mais intensificada pelas demandas trazidas pelos sujeitos. Diante disso, Dubar (2005) aposta na socialização como uma "construção social da realidade" em que entram em confronto as lógicas heterogêneas da ação, bem como as das disposições sociais, convergindo para uma compreensão de que a socialização não pode ser tratada apenas como integração social. Conforme a passagem a seguir, essa crítica é direcionada especialmente às abordagens culturalista e estrutural-funcionalista:

Não se mantém o postulado segundo o qual cada indivíduo procura ou se conformar à cultura do grupo e reproduzir suas tradições culturais, ou otimizar suas riquezas e suas disposições de poder, dependendo do tipo de sociedade em que se encontra. Cada indivíduo é confrontado com essa 
dupla exigência e deve aprender ao mesmo tempo a se fazer reconhecer pelos outros e a obter o melhor desempenho possível. A socialização não pode, pois, se reduzir a uma dimensão única e consiste, nesse caso, em administrar essa dualidade irredutível (DUBAR, 2005: 98).

$\mathrm{Na}$ crítica acima Dubar concebe o processo socializador como a administração de uma dualidade que é irredutível. Qual dualidade compõe o núcleo central da socialização? A problematização dessa questão fundante o leva à filosofia de tradição alemã, especialmente a de Hegel e de Habermas, visando decodificar a construção da dualidade que constitui a base da mediação entre indivíduo e sociedade. Antes de avançar, vale dizer que essa dualidade do social pode ser resumida em integração (se fazer reconhecer pelos outros) e realização pessoal (obter um bom desempenho ao longo da vida).

Claude Dubar articula essa reflexão a partir de duas dialéticas, a primeira diz respeito a trabalho e interação, de Hegel, e a segunda, de Habermas, problematiza ação instrumental e ação comunicativa. Seguindo a leitura de Habermas sobre a Filosofia do espírito de Iena, de Hegel, o autor vai enfatizar que a problematização do processo de socialização nas Ciências Sociais tem sido colocada, especialmente pela teoria clássica, em uma relação entre o "desenvolvimento dos indivíduos levando a identidades sociais e a estruturação dos sistemas sociais que servem de suporte a mundos sociais" (DUBAR, 2005: 99). Em outros termos, a socialização aí concebida entende que a emergência da individualização se dá com a interiorização do objetivo, uma vez que individualização e construção do mundo social são movimentos congêneres. Na operacionalização dessa reflexão estão inscritas três matrizes formadas por aquilo que é o objetivo, o subjetivo e o social e, segundo Habermas, essas matrizes, problematizadas por Hegel na sua primeira teoria sobre a formação do espírito, inspirou a fundação de uma das discussões mais tradicionais da sociologia, a saber, a de entender a socialização.

A socialização refletida com base na dialética trabalho e interação é discutida a partir de duas fundamentais noções: reconhecimento e meio. A interação entre dois ou mais sujeitos pressupõe reconhecimento recíproco, que, no 
âmbito da filosofia de Hegel, é resultado da reconciliação de um processo conflituoso. Com efeito, nesse reconhecimento recíproco está envolvida a dialética universalidade e singularidade que pode ser pedagogicamente compreendida a partir do seguinte: o "eu" só é possível graças ao fato de que o "outro" me reconhece e isso depende do meu próprio conhecimento de que cada um de nós pertence a uma espécie (dimensão universal) e a si mesmo (dimensão particular). Aí consiste um processo de constituição de identidade que, justamente por envolver duas dimensões, implica conflito a ser desenvolvido nas práticas sociais, onde as relações objetivas e as representações subjetivas caracterizam a dualidade do social. Daí que o "o reconhecimento recíproco é, portanto, o ponto de chegada possível, e não o ponto de partida obrigatório, da socialização" (Idem, p. 100).

Atente-se para o fato de que a formação da identidade não se dá numa reflexividade de um "eu solitário", mas numa relação mútua de reconhecimento que, por sua vez, acontece em um meio. Isto é, o indivíduo não se constitui com base em uma reflexão do eu solitário sobre si mesmo, mas através do processo formativo que se dá na socialização. E a socialização aqui entendida pressupõe meio. O meio é indispensável porque nele se desenvolve o processo conflituoso de identificação do universal e do singular (objetividade e subjetividade) portanto, a constituição do sujeito.

$\mathrm{Na}$ dialética de Habermas, por sua vez, as condições estruturantes da identidade são as atividades instrumental e comunicativa. No mundo objetivo as categorias são instrumentais, pressupondo uma identidade reivindicada, ao passo que no mundo social elas são comunicativas e sugerem uma identidade reconhecida. Diante disso, segundo Dubar (2005), a dialética motriz da socialização se situa "entre a dinâmica das atividades instrumentais - sistema de ação racional em relação a um fim, segundo a definição de Max Weber - e a natureza das atividades comunicativas - sistema de poder e de legitimidade, e também de libertação e de reciprocidade" (p. 102).

Um parêntese importante sobre a reflexão de Habermas acerca das transformações societárias, e que nos ajuda a entender melhor o ponto em questão, 
diz respeito à compreensão do mundo da vida em relação à noção de sistema, que caracterizam as sociedades em duas esferas: o da reprodução simbólica e da interação; e o da reprodução material e do trabalho. Segundo Freitag (2005), a noção de sistema é complementar e não oposto ao mundo vivido, e se refere às estruturas societárias que asseguram a reprodução material e institucional da sociedade, como por exemplo, a Economia (subsistema: dinheiro) e Estado (subsistema: poder). São eles que sustentam a integração sistêmica. O sistema é regido pela razão instrumental e a linguagem fica em segundo plano. $\mathrm{O}$ mundo da vida, ou mundo vivido, constitui o espaço do diálogo no qual os atores percebem e vivenciam a realidade social, experimentam aquilo que é comum a todos, como a língua, as tradições e culturas partilhadas. Nele, portanto, predomina a linguagem, "a ação comunicativa", regulada para a integração social ${ }^{8}$.

Habermas faz a defesa da articulação entre razão instrumental, que tem predominado nas sociedades contemporâneas - segundo seu diagnóstico, e razão comunicativa. Desenvolvendo a razão comunicativa, Dubar (2005) defende a tese de que a interação (ação comunicativa) não pode ser restringida às disposições instrumentais (ação instrumental). Dubar a todo o momento mobiliza uma reflexão crítica à postura do tipo funcionalista, que concebe um sistema econômico e social como "totalidade integrada e considera a socialização um processo de integração auto-regulada a esse sistema" (p. 106/07). Acontece que, para ele, a socialização está ancorada em um complexo processo sempre aberto que repousa em combinações múltiplas. No entanto, um pressuposto básico é a ação comunicativa.

Nesse ponto é importante a contribuição de G. H. Mead. De acordo com Dubar (2005), cuja análise estamos acompanhando, ele assinalou a importância de compreender a socialização não sob a perspectiva de uma incorporação passiva de

\footnotetext{
8 “A ação comunicativa surge na interação de, no mínimo dois sujeitos, capazes de falar e agir, que estabelecem relações interpessoais com o objetivo de alcançar uma compreensão sobre a situação em que ocorre a interação e sobre os respectivos planos de ação com vistas a coordenar suas ações pela via do entendimento. Neste processo, eles se remetem a pretensões de validade criticáveis quanto à sua veracidade, correção normativa e autenticidade, cada uma destas pretensões referindo-se respectivamente a um mundo objetivo dos fatos, a um mundo social das normas e a um mundo das experiências subjetivas" (FREITAG, 2005: 164).
} 
valores e regras gerais de um grupo pelo sujeito, mas, a partir da noção de "Simesmo", como um reconhecimento do sujeito como membro que assume um papel útil. Desse modo, o conceito de socialização é definido como uma construção da identidade social que se forja na e pela interação, em que a comunicação é elemento central. O cerne do processo socializador é a "ação comunicativa" e, para tanto, são necessárias formas institucionais que valorizem essa dimensão, já que a socialização não se desenvolve no vazio. É através de instituições orientadas ao reconhecimento do "Si-mesmo" que o grupo social alcança a integração, uma vez que, para Mead, "a socialização vai de par com a individualização: quanto mais se é Si-mesmo, mais se está integrado ao grupo" (DUBAR, 2005: 118). É claro que não se trata de algo linear, ou seja, pode haver dissociações, tais como as existentes entre a socialização primária e socialização secundária ${ }^{9}$.

Essa mobilização teórica de Dubar (2005) consiste em assinalar que a construção social da realidade é problemática e coloca a questão da socialização no centro de uma perspectiva que valoriza o sujeito nas interações, e não como um dado objetivo da ordem social. Destacam-se duas coisas essenciais: identificação com o próximo (dimensão universal) e atitudes/preferências particulares (dimensão singular). É um duplo processo marcado, por um lado, pelo indivíduo apropriando-se subjetivamente de um mundo social a que pertence, e, por outro, identificando-se com papeis e aprendendo a desempenhá-los de modo pessoal e eficaz. É um processo relacional.

Mas essa relação entre o indivíduo e a sociedade não tem a ver com os termos da relação encontrada nos autores discutidos na primeira seção, em que a

\footnotetext{
${ }^{9}$ Essas tipificações ideais são de P. Berger e T. Luckmann, que definem o processo de socialização primária como o momento em que a criança é submetida a um saber básico, fundamental para, simultaneamente, "a posse subjetiva de um eu e um mundo" dos papeis sociais. Em relação à socialização, secundária é uma "etapa" em que o indivíduo tem a oportunidade de desenvolver identidades especializadas (profissionais, culturais, políticas etc.). Segundo Dubar (2005), a articulação entre essas duas socializações é complexa e marcada por sucesso e fracasso, além de considerar que a socialização primária "nunca é totalmente bem-sucedida" e a secundária "nunca é totalmente terminada" (cf. DUBAR, 2005: 122).
} 
socialização exerce a função de forjar papeis para uma ordem social mais estável. A discussão dessa segunda seção mostra que integração e autonomia são termos colocados em outra dimensão da socialização, caracterizada por aquilo que é sucessivo, simultâneo e relacional; fruto de um processo estável e provisório, subjetivo e objetivo. Essa qualidade de uma ordem social construída com base em princípios fragmentados, em referência à pluralidade dos sujeitos com suas demandas, encontra forte ressonância nas reflexões de Dubet e Martuccelli (1997) sobre a experiência escolar.

François Dubet e Danilo Martuccelli (1997) enfatizam que, na sociologia clássica, a articulação entre integração e autonomia é colocada em termos de tensão, e essa forma de encarar a relação entre indivíduo e sociedade proporcionou operações sociológicas posteriores que representam, de um lado, o sistema social, de outro, o ator. $O$ primeiro definiu socialização como "internalização normativa e cultural, afirmando assim a reversibilidade da subjetividade dos atores e da objetividade do sistema", enquanto o segundo "privilegia o tema do distanciamento, da atividade dos indivíduos, da separação entre ator e sistema" (p. 243). Com efeito, a socialização se configura como um paradoxo formado pela integração total do indivíduo, uma própria anulação da ideia de indivíduo, e pela separação entre sistema e indivíduo. Em outras palavras, despejou na socialização a responsabilidade de articular autonomia do indivíduo e integração social. Conforme os autores,

A sociologia clássica pensou o indivíduo por meio da correspondência entre as dimensões subjetivas de sua ação e as dimensões objetivas de seu estatuto (...) Doravante, o indivíduo não é mais definido por uma correspondência estreita entre a objetividade e a subjetividade, mas concebido pela sua maior distância em relação ao mundo. $\mathrm{O}$ problema da socialização torna-se aquele da reflexividade, da crítica, da justificação, do distanciamento. Para dar conta desse processo, é preciso uma vez mais fazer referência a uma diferenciação social crescente que aumenta o fosso entre as posições sociais e as motivações individuais ao ponto em que sua junção não pode ser mais assegurada pelo viés dos esquemas organizados da ação, isto é, pelos papeis (DUBET \& MARTUCCELLI, 1997: 247). 
Dubet e Martuccelli (Idem) assinalam ainda que o distanciamento entre objetividade e subjetividade é uma característica marcante da sociedade contemporânea, uma vez que vivemos em um modelo social que evoca uma desarticulação constante entre os condicionamentos sociais e a socialização dos indivíduos. Não há mais uma correlação tão estável, pois, cada vez mais, "o espaço da iniciativa individual não para de crescer no seio de cada situação socialmente definida". O fato é que as novas complexidades sociais e culturais fundaram situações que requerem dos atores envolvidos uma capacidade de articular sua "distância e sua implicação no mundo". É como se a cada situação socialmente contextualizada os atores devessem saber que existem tarefas objetivas definidas, mas isso não significa que estão submetidos a qualquer disposição (de poder econômico, cultural e/ou social) que os prendam a posições sociais estabelecidas. "No limite, podemos dizer que o indivíduo deve, em cada interação e a cada momento, reconstruir uma socialização secundária" (DUBET \& MARTUCCELLI, 1997: 248).

Os pesquisadores filiam essa trama social à reflexão que enfatiza o ator não como um sujeito cuja ação sente o peso das estruturas, como está bastante claro, mas àquela que o situa como uma "unidade reflexiva e interativa capaz de pensar de maneira autônoma e de adaptar, pelo distanciamento, os símbolos adquiridos às suas próprias necessidades" (Idem, p. 251). Isto é, trata-se de um sujeito capaz de conectar vida social reflexividade. A reflexividade, por sua vez, define-se na situação e nas interações. Daí, então, a socialização se constitui como um processo que se faz na interação, obrigando os indivíduos a agir segundo os contextos que os localizam e, com isso, evita uma relação indivíduo e sociedade desprovida de sentidos, de reciprocidade de expectativas.

Para eles a socialização é complexificada pela heterogeneidade social e cultural que caracteriza o quadro social atual. Essa perspectiva do ator e da situação expõe uma diferença estonteante acerca do conceito de integração que, conforme a proposta dos autores, não tem mais uma noção única. Integração possui duas formas, uma social e outra sistêmica. Segundo Dubet e Martuccelli (1997), a integração sistêmica entende que "a integração da sociedade se opera por intermédio de mecanismos impessoais, notadamente o dinheiro (mercado) e o 
poder (estado), independentemente de um acordo preestabelecido entre os indivíduos", ao passo que a integração social "supõe uma cultura comum aos atores e a possibilidade de coordenar as ações por meio de normas estabelecendo a reciprocidade das condutas" (p. 252).

Dubet e Martuccelli (1997), ao defenderem a importância do sujeito e da interação, convergem com a proposta de Dubar (2005) sobre a construção social da realidade. Só que para eles a noção de situação é crucial. É a situação, ou o contexto socialmente localizado, que registra uma interação ordinária fundada em um conjunto de papeis compartilhado com todos os participantes e que dá sentido às relações entre eles. É onde a socialização ocorre, onde a vida social se imprime a partir da relação face a face em situações específicas. Essa preocupação é uma das questões mais relevantes da sociologia de Erving Goffman, que concebe uma perspectiva de encontro para a compreensão da relação entre sociedade, indivíduo e ambiente. Sobre essa perspectiva do encontro, Goffman fala o seguinte:

Um encontro social é uma ocasião de interação face a face, começando quando os indivíduos reconhecem que se moveram para a presença imediata uns dos outros e terminando com uma retirada aceitável da participação mútua (GOFFMAN, 2011: 97).

Desse ponto de vista, a vida social é um ritual de interação, configurado por um conjunto de representações dos indivíduos a ser definido. Isso nos parece importante para construir os encontros pessoais desenvolvidos na escola e tentar compreender as experiências dos indivíduos com esse ambiente, de modo que, ao montar essa configuração, possamos fazer afirmações acerca do processo de socialização de novos sujeitos.

A perspectiva do sujeito (do ator, para outros) complexifica a socialização escolar pela intensificação das relações entre os indivíduos e um dos desafios a ser enfatizado é o da questão da confiança. Para Giddens (1991), por exemplo, a confiança no mundo contemporâneo é um elemento que se ordena e reordena na vida cotidiana das relações sociais, uma vez que "a confiança em pessoas não é enfocada por conexões personalizadas no interior da comunidade local e das redes de parentesco", mas um projeto a ser "trabalhado pelas partes envolvidas, e requer 
a abertura do indivíduo para o outro" (GIDDENS, 1991: 123). A base da confiança é a reflexividade que se desenvolve na contínua dinâmica das práticas sociais, nas quais o ator também possui uma consciência prática e age conforme algumas regras para a comunicação interativa se realizar e construir novos arranjos societários (Idem). Essa questão pode ser remetida ao caso escolar, onde a confiança seja fruto da relação entre sujeitos.

Alain Touraine (2003) identifica essa possibilidade de novos arranjos serem elaborados com o processo de "desmodernização", que traduz a queda de padrões sociais e a criação de condições para se desenhar novas configurações. Para ele, "se a modernização foi a gestão da dualidade da produção racionalizada e da liberdade interior do sujeito humano pela ideia de sociedade nacional, a desmodernização defini-se pela ruptura dos laços que unem a liberdade pessoal da eficácia coletiva" (p. 36). Nesse sentido, a desmodernização concebe um quadro social em declínio das certezas e, ao mesmo tempo, estabelece as possibilidade para a sua reconfiguração. $O$ fato é que a construção social segue aberta.

As sociedades abertas podem ser vivenciadas como selvagens, mas as sociedades fechadas parecem prisões. Não partamos de um julgamento moral sobre a desmodernização. A queda da sociedade, como modelo de ordem e de integração, produz uma crise social, mas abre também o caminho para a busca de um novo princípio de combinação da racionalidade instrumental e da identidade cultural (TOURAINE, 2003: 37/38).

As mudanças ocorridas com a globalização e com a luta dos movimentos sociais vão de questões da ordem econômica até a destruição das mediações sociais, culturais e políticas que garantiam a integração da ordem clássica. Vistos pelo ângulo da escola, essas mudanças são melhor compreendidas com a massificação do acesso à escola que ocorre no pós-II Guerra Mundial. Embora os efeitos não sejam os mesmos, o fato é que a massificação escolar muda as relações no interior da escola e problematiza ainda mais a produção de novas solidariedades sociais.

Recorrendo novamente a Dubet e Martuccelli (1998), é possível afirmar que a massificação da escola na França foi o fio condutor da transformação do 
sistema escolar republicano, uma instituição mais integrada e que vincula atividades dos docentes à valores sociais elementares. Para os autores, a universalização do ensino modificou as regras do jogo escolar, suas regulações, relações pedagógicas e, ainda, seus vínculos com a sociedade.

Si fuera necessário terner solemente un hilo conductor para analizar las transformaciones del sistema 'republicano' que acabamos de evocar, sería sin duda el de la masificacíon. Más que las voluntades políticas o que los câmbios organizacionales y pedagógicos, la masificación há transformado las reglas del juego escolar, sus regulaciones, las relaciones pedagógicas y los vínculos del sistema con su entorno (DUBET \& MARTUCCELLI, 1998: 46).

A massificação escolar nas sociedades é um processo que veio para ficar. Tal como Alexis de Tocqueville descreveu a inexorabilidade da democracia, Dubet e Martuccelli (1998) afirmam que a massificação escolar é irreversível por independer de governo de direita ou de esquerda, de organizações sindicais ou partidárias. Trata-se de algo contínuo, reivindicado por esses atores e pela opinião pública, por demandas de indivíduos e pelo Estado de bem-estar social, além de realizar alguns dos sonhos e projetos da escola republicana. Com efeito, com base em mecanismos de seleção, a escola de massa não é capaz de produzir justiça social, tal como a republicana, ela mesma forja desigualdades e injustiças.

"Mientras la escuela republicana podia arguir su rol de justicia frente a una sociedad injusta, la escuela de masas produce ella misma las injusticias por sus mecanismos selectivos, pues la igualdad formal esconde los diversos mecanismos graciais a los cuales ciertos grupos conservan sus privilegios. Ya no es la sociedad quien produce la injusticia: es la escuela misma" (DUBET \& MARTUCCELLI, 1998: 52).

A escola republicana estava ancorada em princípios educativos claramente firmados e definidos, tal como a perspectiva da socialização escolar tratada na primeira seção. Contudo, a mutação pela qual passou tem feito novas exigências na dinâmica dos atores da escola e, hoje, há que se admitir que as dinâmicas escolares poussem base de regulação na interação face a face, na ação comunicativa em um ambiente capaz de permitir que as condutas sejam definidas 
a partir de reciprocidades de expectativas. Diante disso, estritamente dentro da escola, uma questão é fundamental: a questão da cultura escolar.

Mas, como a própria socialização produzida pela escola, a questão da cultura escolar ganha particularidades no caso brasileiro. Conforme veremos no próximo capítulo, a universalização da escola no Brasil é fruto de uma luta para afirmar um direito social à camada popular. As particularidades, então, têm a ver com o dilema desigual e excludente que, historicamente, tem caracterizado um apartheid social, especialmente do ponto de vista do acesso à educação. Os autores mobilizados a seguir vão enfatizar que um dos efeitos da nossa massificação escolar é que a escola pública se tornou, especificamente, uma escola para os pobres. Além disso, vão mostrar como foi feita a inclusão, pela escola, do mundo popular no curso das mudanças sociais, como as que vieram com a industrialização. O mais importante efeito desse quadro, para os termos deste trabalho, é toda a complexidade que chega na escola com a universalização do ensino. Então, o caminho a ser percorrido no capítulo a seguir pretende mostrar que a noção de cultura escolar pode ser um importante ponto de visão para entender essa complexidade com a qual a escola tem que lidar.

Recolocando o problema: A questão da relação entre indivíduo e sociedade é uma discussão fundante das ciências sociais e tem sido refletida em diversas dimensões. Dela, elegemos problematizar o processo de socialização escolar porque a escola tem sido afirmada como central na vida de diferentes camadas sociais e parece ser importante enfrentar essa questão a fim de compreender os limites e as potencialidades da escola na sociedade brasileira. Essa investigação é realizada com base em episódios de recreios que, como veremos, apresentam pontos sensíveis do processo de socialização escolar de crianças e adolescentes dos segmentos populares. Contudo, para melhor compreender essa questão, percorremos parte da teoria social para situar a relação escola e sociedade e, consequentemente, extrair ferramentas de análise da socialização escolar.

Como vimos neste capítulo, esse debate sobre a socialização escolar, por motivos de simples organização do raciocínio, foi realizado a partir de uma leitura estratégica em que pese as análises macro e microssociológicas, que, além de ser 
uma forma de colocação das questões sociais contemporâneas, leva aos grandes pensadores da nossa disciplina. Mas, a preocupação central é a de encaminhar esse debate para a interdenpendência da instituição escolar e o seu público, isto é, saber como se dão as formas comunicativas e os seus efeitos: ou, quais os efeitos da socialização da escola pública no Brasil? Essas perguntas são estímulos para investigar a relação da escola com o seu público, permitindo, com isso, avançar na compreensão do lugar e papel da escola na sociedade brasileira e, de modo específico, na compreensão da experiência escolar do mundo popular. Para tanto, o próximo passo da investigação é explorar o movimento de afirmação da escola para as classes populares a fim de compreender o processo educacional em curso na sociedade brasileira. Nosso caminho tomará a noção de cultura escolar como ângulo privilegiado para iluminar a complexidade que chega na escola com o processo de massificação escolar. 


\section{Cultura escolar e socialização escolar no Brasil}

Cultura escolar e socialização são conceitos complementares à compreensão das formas institucionais e dos processos educativos. Ambos os conceitos são entradas que organizam bem o pensamento sobre os fenômenos escolares que daí surgem e suas implicações na realidade social: enquanto a cultura escolar permite acessar um jogo de tensão entre diferentes matrizes de culturas que, naturalmente, desafiam o trabalho escolar especialmente no que diz respeito ao fato de considerar os contextos culturais dos alunos sem cair no extremo do relativismo, a socialização é uma chave de entendimento da complexa interação entre as afirmações individuais dos alunos, que remetem às culturas de origem, e a prática institucional que circunscreve o processo de ensinoaprendizagem a uma determinada sociedade.

Os episódios que serão apresentados a seguir no capítulo do recreio mostram o quão complexa é a escola pública. Pois, tratam de situações que revelam tensões próprias de um espaço-tempo forjado por uma sociedade que tardiamente se desafia a resolver o problema da integração. Não à toa o saldo contemporâneo da questão educacional brasileira é de um enorme déficit.

Mas, essa complexidade é um fato de um novo pacto, qual seja, o de que à escola pública brasileira foi depositado o poder de corrigir inequidades. Isto é, a essa instituição social foi claramente confiada a realização de princípios, recentemente afirmados com a nossa última constituição, para a consolidação de uma sociedade democrática. Então, se por um lado a escola enfrenta dificuldades colocadas por esse desafio, por outro ela está vivendo um momento oportuno para redefinir os termos da relação com um público historicamente excluído de seus capitais. A escola tem uma missão: contribuir para a construção dos papeis sociais fundamentais ao projeto de democracia, em que a igualdade social seja afirmada como elemento central na nossa sociedade. Com efeito, como se trata de um horizonte, uma pergunta se faz necessária: como tornar o processo de socialização e cultura escolar desenvolvido pela/na escola potencialmente a serviço da 
integração do mundo popular nos termos de uma sociedade mais igualitária? Não tenho a pretensão de responder a essa questão, mas tomá-la como um pano de fundo mais amplo a fim de problematizar a relação escola e sociedade estabelecida na nossa ordem social, bem como encontrar ferramentas que ajudem a iluminar os dilemas escolares por trás da dinâmica do recreio.

Então, seguindo esse raciocínio, duas perguntas são indispensáveis acerca dessa nossa proposição: quais os termos da nossa expansão escolar: ou, o que configura o movimento de expansão da escola no Brasil? E, qual tem sido o sentido da escola brasileira: ou, ela tem criado um ambiente para ensinar e educar? A primeira pergunta servirá de inspiração para resenhar o processo de expansão da oferta do ensino público obrigatório, ao passo que a segunda nos ajuda a analisar a complexidade inerente à relação entre a escola e o segmento popular e como a noção de cultura escolar pode ser um bom lugar de visão. Em termos mais curtos, em primeiro lugar, a ideia é explorar o movimento de afirmação da escola para o mundo popular e, posteriormente, pensar as mudanças instituicionais e suas contradições e tensões que se revelam na relação entre a escola e seu público, conforme mostram os episódios de recreio.

\subsection{A oferta da escola pública às classes populares no Brasil}

Organizar o quadro sobre a expansão da escolarização realizada no Brasil é certamente uma construção que exige, desde o início, considerar a existência de diversas formas de encarar a questão. $\mathrm{O}$ objetivo aqui consiste em mobilizar algumas análises acerca da constituição e mudanças da nossa escola pública, atentando para as tensões e contradições inerentes ao movimento de sua afirmação enquanto instituição socializadora das classes populares.

A ampliação da escola, movimento que pode ser entendido como fruto da forte insistência em um processo de afirmação da igualdade como um direito 
social em terras de privilégios ${ }^{10}$, traz consigo um profundo debate em que as marcas da contradição, da tensão e dos conflitos político-ideológicos materializam o penoso desafio das classes populares de ter o direito de estudar garantido. Esse direito de ter escola, como sabemos, apesar de perpassar toda a ideia de modernização da sociedade com suas promessas de igualdade e de democracia não chegou a ser realizado tão facilmente porque um conjunto de perspectivas divergentes concorreu para dificultar a implantação desse projeto, retardando a formulação de alternativas que viessem, de alguma forma, modificar a configuração de exclusão social e política no país. Mas, a partir de que momento da historia essa realidade de exclusão deixa de ser tão naturalizada? Isto é, efetivamente, em que condições a escolarização passa a fazer parte do mundo popular?

As análises que tratam da ampliação da oferta escolar mostram que ao longo do século $\mathrm{XX}$ as classes populares, em sua diversidade de pobreza e etnia, vivenciaram um lento processo de democratização do ensino. A década de 1920 parece ser um ponto de partida interessante para compreender esse ponto, pois é neste período que emerge uma primeira proposta de universalização da alfabetização para todas as crianças em idade escolar ${ }^{11}$. Na década de 1920 ocorria um conjunto de reformas educacionais nos estados que efetivamente não conseguiu modificar o quadro de exclusão do ensino. De acordo com Saviani (2004), a reforma encabeçada por Sampaio Dória no estado de São de Paulo, por exemplo, apesar de procurar insituir uma escola primária, “cuja primeira etapa,

\footnotetext{
${ }^{10}$ Essa ilustração do privilégio como importante presença na sociedade brasileira é mais bem localizada nas relações pessoalizadas que buscam suspender o ritual onde a igualdade é tida como a unidade básica da socialidade. Roberto DaMatta (1997) mobiliza o "sabe com quem está falando" para resenhar os pormenores dessa questão no nosso universo social. Do ponto de vista histórico, não esqueçamos as manobras de "inserção" dos negros com o fim da escravidão, cuja forma privilegiou a permanência da estrutura de poder assimétrica da relação racial entre brancos e negros, isto é, uma "inserção" de negação da igualdade.

${ }^{11}$ Dermeval Saviani (2004), em A escola pública brasileira no longo século XX, afirma que as transformações mais relevantes da sociedade brasileira nos âmbitos econômico, político, cultural e, inclusive, educacional estão localizadas duas décadas antes da virada para o século XX, ou seja, em 1880. No entanto, o pesquisador reconhece que o marco da questão educacional para as massas é a década de 1920 e o período de 1931 a 1961 caracteriza a "regulamentação, em âmbito nacional, das escolas superiores, secundárias e primárias, incorporando crescentemente o ideário pedagógico renovador" (p.02).
} 
com a duração de dois anos, seria gratuita e obrigatória para todos", nunca chegou a ser uma realidade naquele estado.

O esforço dessa reforma é uma das tentativas de integrar os excluídos do direito básico, os "deserdados" da educação, à dinâmica de modernização da organização político-econômica, cuja nataureza tem como referência a ideia de progresso social com a industrilização em curso na Europa e nos EUA. Essa questão vai ganhar um capítulo de destaque na década de 1930, em que intelectuais como Anísio Teixeira e Fernando de Azevedo lançam um documento, o Manifesto dos Pioneiros da Educação de 1932, que articula a reconstrução da vida social brasileira à oferta obrigatória de ensino público gratuito a todos.

O manifesto de 1932 é uma importante ferramenta na compreensão da condição educacional brasileira nos "43 anos de regime republicano" e, particularmente, o das classes populares nessa realidade. Quanto à situação educacional brasileira o Manifesto (1932) chega a falar de um esforço "sem unidade de plano e sem espírito de continuidade" do sistema escolar desenvolvido até então que, segundo esse documento, representava um distanciamento frente às "necessidades modernas e das necessidades do país" (p. 33). As principais causas da precária condição educacional, que, por sua vez, evidenciava uma baixa possibilidade de oferta para o mundo popular, eram a "fragmentação e a desarticulação" de reformas, precisamente "parciais e arbitrárias", que não conseguiram reagir aos problemas a fim de transformar a crítica situação escolar e, por extensão, realizar a integração de uma importante camada social. O Manifesto argumenta que uma dimensão política está por trás da permância dessa estarrecedora ausência de escolarização na sociedade brasileira, e ela pode ser vista pelo ângulo da "falta de espírito filosófico e científico" permeando os debates sobre a "resolução dos problemas da administração escolar", isto é, a reflexão sobre a escola não estava ancorada numa perspepectiva mais ampla e, nesse sentido, era difícil configurar um entendimento acerca dos objetivos e 
finalidades educacionais que fugisse de um "empirismo grosseiro"12. A argumentação em seguida traz esse ponto.

Não se podia encontrar, por isso, unidade e continuidade de pensamento em planos de reformas, nos quais as instituições escolares, esparsas, não traziam, para atraí-las e orientá-las para uma direção, o pólo magnético de uma concepção da vida, nem se submetiam, na sua organização e no seu funcionamento, a medidas objetivas com que o tratamento científico dos problemas da administração escolar nos ajuda a descobrir, à luz dos fins estabelecidos, os processos mais eficazes para a realização da obra educacional (AZEVEDO, 1932: p. 34).

Compreendendo esse lugar da escola, bem como o diagnóstico da falta de escolarização, os signatários do manifesto emergem com a proposta de encarar a escola como uma instituição que, em articulação com outras organizações sociais, possa influir no meio social de modo que, sua prática, não esteja em comum acordo com a realidade de segregação classista, mas que possa atingir "o músculo central da estrutura política e social da nação" (p. 38). Trata-se, portanto, de uma proposta que visa realizar uma reforma social que passe pela escola, pois, de acordo com o Manifesto (1932), não é possível mudar a difícil situação social do país senão pela "ação extensa e intensiva da escola sobre o indivíduo e deste sobre si mesmo", ação que paulatinamente vai transformar a própria relação entre escola e sociedade.

De modo sintético, o Manifesto dos Pioneiros apresenta uma proposta que consiste na afirmação da educação enquanto ação legitimadora não dos interesses de classes, como enfatiza o exercício de sua função até então, mas do reconhecimento do direito de todo indivíduo ser educado até onde o permitirem "suas aptidões naturais, independente de razões de ordem econômica e social". A tarefa é instituir o princípio da igualdade através do acesso à educação escolar, em qualquer de seus níveis de ensino, de modo que a dinâmica da sociedade brasileira passe a ter unidades de diferenciação social que vão além do econômico. No trecho a seguir, essa questão é colocada de forma clara.

\footnotetext{
${ }^{12}$ Esse ponto corresponde à crítica sobre a educação escolar baseada nos interesses de classe, e não nos indivíduos, estabelecendo uma clara relação entre escola e meio social. O entendimento é que essa perspectiva faz do homem um instrumento exclusivamente para a produção e não um sujeito de participação na sociedade política.
} 
A educação nova, alargando sua finalidade para além dos limites das classes, assume, com uma feição mais humana, sua verdadeira função social, preparando-se para formar "a hierarquia democrática" pela "hierarquia das capacidades", recrutadas em todos os grupos sociais, a que se abrem as mesmas oportunidades de educação. Ela tem, por objeto, organizar e desenvolver os meios de ação durável, com o fim de "dirigir o desenvolvimento natural e integral do ser humano em cada uma das etapas de seu crescimento", de acordo com uma certa concepção do mundo (AZEVEDO, 1932: 40).

Os signatários do Manifesto de 1932 reconheciam a falta de condições da família popular para escolarizar formalmente seus filhos, especialmente pela estrutural contingência econômica, e, diante disso, defendiam que o Estado deveria assumir a responsabilidade de ofertar o ensino, principalmente quando o torna obrigatório, ou seja: “o Estado não pode tornar o ensino obrigatório, sem torná-lo gratuito" (p. 45). E, avançando na defesa do modelo de escola, a proposta de educação pública emerge com os princípios de laicidade, gratuidade e obrigatoriedade como fundamentais à consolidação de uma nova instituição que pretende quebrar, portanto, com uma lógica institucional que possui em sua trajetória uma arquitetura de entrelaçamento a interesses de grupos sociais com poder de pressão - as classes dominantes (políticas e religiosas) brasileiras. Ao fazerem a crítica de que o interesse da escola pública não pode convergir com interesses transitórios, os signatários do manifesto articulam o interesse da escola à formação integral das novas gerações e, desse modo, propõem a implantação da "escola unificada", que funcionaria sob o signo da igualdade pondo em um mesmo lugar, segundo o manifesto, "alunos de diferentes condições sociais e biológicas". Era a defesa de uma democracia republicana no Brasil pela elite intelectual modernista.

O redirecionamento da função social da escola defendida no Manifesto dos Pioneiros encarrega ao Estado o dever de proclamar a educação como algo eminentemente público e, mais especificamente, lhe confere a operacionalidade desse projeto que consiste na educação integral para todos os indivíduos de modo que aqueles cidadãos "a quem a estrutura social do país mantém em condições de inferioridade econômica" possam usufruir ao "máximo de desenvolvimento de acordo com suas aptidões vitais” (p. 44). A escola pública, laica, universal e gratuita é a forma encontrada pelo movimento da Escola Nova de instituir a 
igualdade de oportunidades sobre a qual se realizaria a diferenciação forjada pelas qualidades pessoais.

Essa proposta de intervenção encontra no Estado as potencialidades para se tornar o ator portador do projeto de modernizar o sistema de ensino através da instituição da "escola única", que serviria de palco para o desenvolvimento da formação escolar da classes populares, de modo que a afirmação da escola possibitasse uma realidade com menor exclusão social. Por esse princípio chegase à reforma de que necessita a dinâmica do período de modenização social brasileira, cujos aspectos mais emblemáticos são as restrições de direitos sociais fundadas na separação das classes.

\begin{abstract}
Afastada a ideia do monopólio da educação pelo Estado, num país em que o Estado, pela sua situação financeira não está ainda em condições de assumir sua responsabilidade exclusiva, e em que, portanto, se torna necessário estimular, sob sua vigilância, as instituições privadas idôneas, a "escola única" se entenderá, entre nós, não como "uma conscrição precoce", arrolando, da escola infantil a universidade, todos os brasileiros, e submetendo-os durante o maior tempo possível a uma formação idêntica, para ramificações posteriores em vista de destinos diversos, mas antes como a escola oficial, única, em que todas as crianças, de 7 a 15, todas ao menos que, nessa idade, sejam confiadas pelos pais à escola pública, tenham uma educação comum, igual para todos (AZEVEDO, 1932: 44).
\end{abstract}

Nessa passagem, como podemos observar, está presente o sentido de "escola única" esboçado no Manifesto. Trata-se de uma forma de ofertar a escolarização comum a todos os indivíduo que tenham entre 7 e 15 anos de idade, cessando com o sistema que privilegia a classe detentora de capitais ao não admitir, "dentro do sistema escolar do Estado, quaisquer classes ou escolas, a que só tenha acesso uma minoria, por um privilégio exclusivamente econômico" (p. 44). Essa noção de "escola única" faz parte do conjunto de medidas que consagram um esforço programático de reforma do sistema educacional presente no Manifesto redigido por Fernando de Azevedo e lançado em 1933. Isso porque está presente um diganóstico que ressalta a oferta educacional restrita a determinados segmentos sociais. A patir de então, evidentemente considerando o debate que vem ocorrendo desde os anos 1920, começa a ganhar folêgo a ideia de uma escola que atendesse a todos. No entanto, a sua realização não acontece 
imediatamente, passa por um processo de profundo conflitos de interesses que vai desenhar os traços gerais de uma expansão escolar à brasileira.

O debate em torno da educação estava organizado entre os partidários da universalização do ensino e os que defendiam formação escolar de acordo com cada segmento localizado na estrutura de poder da sociedade. A educação se materializa enquanto um campo de disputa ideológica/política em que movimentos como a Escola Nova e instituições como a Igreja Católica e a Militar entram em confronto ao afirmar perspectivas distintas do papel conferido à educação, sendo o pensamento escolanovista, como acabamos de ver, a favor de uma reforma que visa a renovação democrática da escola pública, ao passo que, ao contrário, a Igreja Católica imprime um esforço a fim de garantir o seu poder de dominação na maioria das instituições de formação escolar. Esse conflito de interesse vai permear o debate em torno da construção do Plano Nacional de Educação a ser enviado para aprovação do Congresso em 1937.

De acordo com Schwartzman, Bomeny e Costa (2000), à frente do Ministério da Educação, em 1936, Gustavo Capanema organizou um questionário com perguntas sobre princípios, finalidades, sentidos, organização, burocracia, conteúdo, metodologia entre outras questões e enviou para diversos setores organizados da sociedade brasileira com o objetivo de reunir as mais diversificadas posições que dariam lugar à formulação do Plano Nacional de Educação. Como notam os referidos autores:

A Confederação Católica de Educação inicia uma série de conferências com o objetivo de apresentar um documento único com o ponto de vista católico. A Defesa Nacional faz uma chamada à corporação militar para formular um documento a ser enviado ao Estado-maior do Exército, expressando a opinião militar sobre o plano. Sugere para tanto que o questionário seja respondido por todos os militares, naquilo que mais de perto interessasse ao Exército. Intelectuais de destaque também recebem o questionário, mandam suas respostas ao ministro e participam de conferências públicas cujos resultados são posteriormente reproduzidos pela imprensa (SCHWARTMAN, BOMENY \& COSTA, 2000: 193).

Analisando os pormenores dessa inicitiva, os autores mostram que a Igreja Católica era responsável pela quase totalidade das escolas no país e, diante disso, "via com receio a subordinação da educação ao Estado", tal como defendiam os representantes da Escola Nova em nome da igualdade social, justamente para não 
perder o seu poder de pautar a concepção e o modelo educacional no país. E é em defesa dessa realidade de poder de oferta da formação educacional que a Igreja vai se posicionar a favor da "total liberdade de ensino e autonomia das escolas", justificando que, de um lado, a implantanção da "escola única" seria uma "tentativa de emburguesamento do operariado compulsando os mais capazes numa classe de intelectuais técnicos e universitários" (SCHWARTMAN, BOMENY E COSTA, 2000: 194), quando para ela as condições operárias exigiam apenas cursos secundários paralelos à atividade produtiva, servindo como "oportunas pontes de transferência", e não entrariam em desacordo com as próprias competências das classes populares; de outro, seria necessário evitar o desenvolvimento de valores como o individualismo e as concepções socialistas que prejudicariam e colocariam em xeque as bases do valor à família. Portanto, conforme Schwartzman, Bomeny e Costa (2000), enquanto a Escola Nova "via na educação um instrumento de neutralização das desigualdades sociais, a Igreja a percebia como tendo por finalidade a adaptação dos desiguais a uma ordem social naturalmente hierárquica” (p. 194).

Como mostram Schwartzman, Bomeny e Costa (2000) essa conjuntura de construção do Plano é de grande dissenso sobre as questões educacionais no país, tida como instrumento fundamental para construir os homens e a nação que se quer. A educação escolar é um capital de poder, cuja disputa ocorre na política e pelas alianças erguidas com a Revolução de 1930. Quanto ao plano, embora tenha sido encarado como "belo gesto" do ministério de Capanema, por detatalhar a forma e o conteúdo do ensino não chegou a ser consolidado tal como fora pedido por Capanema à Câmara: "aprovação global". Segundo o trabalho desses autores, o plano se mostrou utópico por, de um lado, mostrar-se enquanto documento que se propõe a resolver "não só as questões de ensino, como também as de ordem social, econômica, política e moral do país"; e, de outro, por mostrar-se crente "no poder das leis e da máquina burocrática em levar à frente um projeto destas dimensões, sem considerar, novamente, a complexidade do país e as limitações inevitáveis da autoridade legal” (p. 204), isto é, a capacidade limitada do Estado.

Esse ponto da capacidade limitada do Estado é também assinalado por Algebaile (2009). Para esta pesquisadora, a autoridade legal tem uma participação 
de complementariedade na oferta de ensino para a população. Ao verificar a Constituição de 1937, no capítulo sobre educação e cultura, Algebaile afirma que "a oferta educacional do Estado era sempre apresentada numa perspectiva suplementar à ação da família, especialmente nos casos em que esta se mostrasse sem condições de fazê-lo" e, além disso, embora esteja inscrita a "obrigatoriedade e a gratuidade do ensino primário", não há clareza quanto à efetiva definição dos termos dessa obrigatoriedade, ou seja, sua aplicação. Pois, "nada se falava sobre financiamento da educação", deixando implícito que no contexto do Estado Novo "até a gratuidade era relativizada", uma vez que a própria "Constituição previa a possibilidade de cobrança de 'quantia módica' para a caixa escolar” (p. 101).

Longe de ser involuntária, essa limitação é uma posição assumida pelo Estado. Ao assumir a condição de conciliador dos interesses das frações de classes, o Estado postulou uma governabilidade da expansão educacional que constitui um lento avanço em matéria de afirmação da escola comum no amplo território nacional e na vida das pessoas com escassas condições de acesso ao ensino. Conforme análise de Algebaile (2009), isso fica mais claro com a própria ação do Estado estipulada nos marcos dos decretos educacionais, como a Lei Orgânica do Ensino Primário de janeiro de 1946, onde está presente que embora o ensino primário elementar (com quatro anos de duração) seja definido como obrigatório (para a faixa etária de 7 a 12 anos), a responsabilidade "era fundamentalmente definida como responsabilidade civil” (p. 103), e não do Estado, deixando margem para a reprodução de um modelo escolar que expressa profunda desigualdade no interior da vida social.

Nesse sentido, ao transferir a responsabilidade à sociedade civil, o Estado se mostra ao mesmo tempo incapaz de ser o portador do projeto de democratizar a escola, de prover educação formal para todas as crianças, e sustentáculo do retardamento da materialização da educação como direito social, ainda mais com o seu esforço mínimo de pedir “cooperação dos proprietários agrícolas e das empresas 'em cuja propriedade se localizar estabelecimento de ensino primário', no sentido de 'facilitar e auxiliar as providências que visem à plena execução da obrigatoriedade escolar"”. 
Duas conclusões: primeiro, isso faz parecer que o "baixo ingresso na educação escolar decorria não da insuficiência da oferta educacional, mas apenas dos impedimentos criados pela sociedade para a sua realização plena" (ALGEBAILE, 2009: 103); segundo, essa escolha transfere para os grupos com poder local a emergência e regulação da cidadania a ser conquistada com a integração escolar. Quer dizer, a cidadania forjada pela socialização escolar fica a cargo de grupos locais com poder, "tentativa que não fortuitamente parecia coadunar-se à ideia de 'cidadania regulada', formulada por Wanderley Guilherme dos Santos (Idem:105).

O desafio educacional era imenso. A discussão que se desdobra desde os anos 1920, o evidente fôlego no âmbito do "reconhecimento""13 que ganhou com o Manifesto dos Pioneiros nos anos 30 e a disputa em torno da construção do Plano Nacional da Educação são passos que oficializam que um direito está em formação. Entrento, não se trata de algo com certa regularidade, as conquistas não são lineares. Pois, segundo Algebaile (2009), enquanto a Constituição de $1934^{14}$ estabelece maior detalhamento nas obrigações orçamentárias para subsidiar a oferta educacional entre as unidades de governo, a de 1937 dilui essas obrigações:

[na Constituição de 1934] Um dos principais avanços refletiu-se nas disposições sobre o financiamento da educação. Aliás, os itens relativos ao financiamento eram os que melhor indicavam, ainda que precária e contraditoriamente, a tendência a um maior alcance da oferta pública ( $\mathrm{p}$. 99).

(...) A Constituição do Estado Novo, de 10 de novembro de 1937, viria a diluir o sentido de dever do poder público que aí se formava [de modo específico no plano orçamentário, que confere protagonismo na ação do Estado], atribuindo ao Estado função apenas coadjuvante na escolarização ‘obrigatória' (ALGEBAILE, 2009: 101).

\footnotetext{
${ }^{13}$ A noção de "reconhecimento" é no sentido afirmado por Algebaile (2009), entendendo-o como termo que indica que a "história de um direito social antecede e atravessa o momento de sua consagração jurídica, aparecendo inscrita nos processos em que esse direito começa a ser socialmente elaborado, nas apropriações instrumentais de suas prerrogativas para fins diversos, nos movimentos e lutas para que ele passe a fazer parte do estatuto de determinada sociedade e chegue a se realizar efetivamente no plano da vida social" (p. 96).

${ }^{14}$ É na Constituição de 1934 que "pela primeira vez a educação foi definida como um 'direito de todos', que devia ser proporcionado 'pela família e pelos poderes públicos” (p. 99).
} 
Com esse exame da constituição jurídica da educação como direito no Brasil, entendendo constituição jurídica leis e emendas de leis, Algebaile (2009) afirma que o percurso trilhado por esse direito é "lento e oscilante"; tem se mostrado uma instituição fragilizada e ele mesmo [o direito] apresenta mudanças que, algumas vezes, "não constituem avanços, mas perdas importantes em relação a conquistas já aparentemente encaminhadas" (p. 97), como o caso das constituições de 1934 e 1937 quanto à responsabilidade orçamentária.

Um passo importante com vistas à concretização do direito à educação escolar foi dado na Constiuição de 1946 que, ao contrário das outras, deixou mais claro os termos de aplicação do princípio de que "o ensino primário é obrigatório" ao alterar esse texto para "o ensino primário oficial é gratuito para todos" (idem, p. 104), sendo a retomada da descrição de percentuais referentes às responsabilidades orçamentárias das unidades de governo representando uma importante disposição para a sua realização. Essa regulação dos percentuais mínimos de investimento foi reiterada na LDB de 1961 que, inclusive, inovou ao forjar as alíneas "manutenção e desenvolvimento do ensino" e "despesas com o ensino" como conceituações da aplicação financeira na área.

No entanto, como mostra Algebaile (2009), as mudanças que apresentam mais precisões são acompanhadas de uma ambiguidade revelada na regulação da responsabilidade civil da oferta educacional: no caso da Constituição de 1946 "o inciso III do art. 168, que dispunha sobre a obrigatoriedade, determinava que em empresas industriais, comerciais e agrícolas em que trabalhassem mais de cem pessoas fosse mantido o ensino primário gratuito para seus servidores e seus filhos (p. 105)"; no inciso II do art. $3^{\circ}$ da LDB de 1961 consta que a responsabilidade com a educação obrigatória é dever principalmente da família, sendo a ação do Estado com "encargos educacionais" somente "quando provada a insuficiência dos meios da família e dos demais membros da sociedade" (p. 106). Neste caso, a efetiva responsabilidade do Estado com a educação obrigatória é basicamente indicativa, configurando uma atução minimalista quanto à oferta escolar. A esse respeito, diz Algebaile:

Todavia, a responsabilização efetiva do Estado quanto à realização da obrigatoriedade não ocorreu. Não havia nenhuma referência textual à 
obrigação de oferta de vagas escolares a todos, ficando subentendido que a medida de suficiência de vagas era dada pelo atendimento das famílias à chamada pública, efetuada pelo Estado, para a matrícula. Inúmeros mecanismos da regulação da oferta mantiveram-se imprecisos ou abriram brechas para a não efetivação da ampliação do número de vagas públicas como prioridade (ALGEBAILE, 2009: 106).

Algebaile (idem) interpreta essa ambiguidade, bem como a existência de imprecisões normativas e a ausência de normatizações mais ousadas, como uma representação da forma peculiar de "contenção efetiva do ritmo de expansão dos direitos sociais". Especificamente, a maneira como o Estado age com a obrigatoriedade escolar "atenua a concepção pública do sentido de dever que deveria presidir sua atuação nesse campo", e essa postura, de certo modo, contribui para a afirmação do sentido restrito de "direito à educação" à classe popular brasileira.

O Estado assume uma obrigação mais precisa na solução da precária oferta educacional no país, no sentido de conferir maior acesso ao ensino, com a Constituição Federal de 1988 e, posteriormente, em 1996, com a LDB. Na CF 88, referente à obrigatoriedade e à garantia do ensino gratuito, consta que o Estado deve ofertar "ensino obrigatório e gratuito" a todos por se tratar de "direito público subjetivo" e a não realização desse dispositivo legal, ou sua realização insuficiente, consiste em "responsabilidade de autoridade competente". Quanto à LDB de 1996 há a ratificação desse direito público subjetivo e formas de responsabilização do poder público que não assegurar o direito social à educação.

Portanto, como vimos, podemos dizer que a expansão da oferta escolar ganha maior territorialidade quando o Estado $^{15}$ efetivamente assume a responsabilidade por sua produção, o que não aconteceu sem a pressão de alguns setores sociais, em especial o clamor de alguns intelectuais e de movimentos sociais (como as lutas pela educação popular nas décadas de 50/60), e, mais à frente, de organismos internacionais que representam fielmente o movimento da

\footnotetext{
${ }^{15}$ No caso, como bem assinalaram os Manifestos de 32 e 59, não se trata de "centralismo", mas de uma ação conjugada da federação a fim de assumir o papel na garantia do direito social à educação, portanto, o Estado não deixa à iniciativa privada a responsabilidade na oferta e garantia desse direito - torna-se ator principal e não coadjuvante do processo.
} 
"difusão mundial da escola"16. Não esqueçamos que, assim como aconteceu em 1932 por iniciativa dos Pioneiros da educação nova, em 1959 pensadores da educação lançaram um manifesto intitulado "Mais um vez convocados: manifesto ao povo e ao governo", redigido por Fernando de Azevedo, para reafirmar, nos anos que antecederam à aprovação da $\operatorname{LDB}$ de $1961^{17}$, a importância da ampliação, pelo Estado, do ensino público, que historicamente tem sido construído lentamente "peça por peça, através de dificuldades imensas" (AZEVEDO, 1959: 88).

É bom registrar que o manifesto de 1959 argumenta a favor da expansão escolar no contexto do pós-guerra em que, pelo menos até 1970, a socialdemocracia europeia enfatiza a responsabilidade do Estado em ampliar sua capacidade de atendimento com vistas a promover mais justiça social. Aqui, no Brasil, pela democracia liberal, o referido Manifesto, apesar de não falar em justiça social, expressa nuances que correspondem a esse princípio: "Que o país pelos seus órgãos competentes não tenha cumprido os seus deveres para com as novas gerações, sistematicamente esquecidas e entregues, em grande parte, à sua própria sorte, não há sombra de dúvida. Os fatos aí estão para atestá-lo com uma evidência agressiva" (AZEVEDO, 1959: 75).

Esse documento ratifica também que a escola pública é uma conquista consagrada em outras nações e que o Brasil não pode ignorar esse processo. Logo, ao Estado compete promover a educação pública de modo a constituir os princípios e as instituições democráticas, bem como produzir a sua riqueza pelos termos do progresso científico e tecnológico: “Toda a história do ensino nos tempos modernos é a história de sua inversão em serviço público. É que a educação pública é a única que se compadece com o espírito e as instituições democráticas, cujos progressos acompanha e reflete, e que ela concorre, por sua vez, para fortalecer e alargar com seu próprio desenvolvimento" (Idem: 89).

${ }^{16}$ Cf. NÓVA \& SCHRIEWER, 2000.

${ }^{17}$ A LDB de 1961 é, na verdade, segundo Algebaile (2009), resultante do projeto elaborado entre 1947 e 1948. Exatamente, a sua aprovação se deu após apenas 13 anos de intensos debates e numerosas emendas. 
Então, sendo fiel à pergunta colocada no início dessa seção (quais o termos da nossa expansão escolar: ou, o que configura o movimento de expansão da escola no Brasil?), depois de resenhar algumas linhas básicas, podemos trazer como reflexão alguns pontos.

Um primeiro é que durante muito tempo a ampliação da escola para as classes populares não se revelou como uma questão social (portanto, não a situando no campo do direito à igualdade social) a ser solucionada pelo Estado. É somente no período 1920-1930 que começam a ganhar notoriedade as possibilidades da escola se tornar a via pela qual o filho da classe popular deverá ser socializado. Mas, na verdade, esse período marca o início de uma luta que se desenvolve, basicamente, entre duas perspectivas diferentes da relação escola e sociedade: para uma, a escola deve ser compreendida como uma instituição que atenda à "vocação" da sociedade, isto é, se é uma sociedade de classe a escola a legitima conferindo formação educacional correspondente, pois da estrutura de classe deriva todo o sistema social - essa perspectiva pode ser vista na defesa da Igreja em "preservar a liberdade de ensino"; para outra, a escola é vista como uma instituição republicana que deve educar as classes populares para a dinâmica da sociedade capitalista e inserção no regime democrático.

Um segundo ponto, é que o movimento da expansão da educação brasileira ocorre concomitantemente com a implantação do processo de industrialização e da construção do nacionalismo. De acordo com Saviani (1991: 64), "essa bandeira da industrialização aglutina um conjunto grande de forças que vão desde a incipiente burguesia nacional, passando pela burguesia internacional e as camadas médias, até as forças de esquerda", de modo que em campos importantes, como o educacional, apesar de ter ganhado mais visibilidade, persiste a incorporação dos interesses das forças de pressão, as quais, de certo modo, não modificaram questões de base, como o caráter segregador da educação. Isto é, ao algutinar os interesses dos grupos sociais, o Estado incorporou demandas que retardaram reformas sociais promotoras de uma nova dinâmica da relação entre as classes sociais no Brasil. 
E outro, um terceiro, decorrente do primeiro, é que, ao demorar a considerar que a expansão escolar era uma questão social, o Estado, visando à industrialização e nacionalização, caracteriza-se como um agente disposto a ofertar o "mínimo". A noção "mínimo”, conforme Algebaile (2009: 95), é substancialmente diferente da noção "básico": enquanto "mínimo" faz referência a limites ínfimos de satisfação, "básico" é uma noção "que serve de base de sustentação indispensável e fecunda ao que a ela se acrescenta". Nesse sentido, não por acaso existem imprecisões nas regulamentações e fragmentação nas ações da ampliação da escola.

Pois bem, a questão da ampliação escolar tem uma trajetória complexa e longe de ser algo tão recente. Na verdade perpassa quase todo o século XX, mas só ganha efetivamente força quando entendida como uma instituição relevante para a construção da sociedade democrática. É, então, especialmente no período entre 1960 e 1980, sob essa articulação escola/democracia, que a instituição escolar assume crescente protagonismo na socialização das crianças e adolescentes do mundo popular ${ }^{18}$.

Como podemos ver, então, da nossa escola atual exige-se um trabalho de incorporação dos pobres por uma instituição que, desde o início da republica, tem sido forjada com a proposta de privilegiar as elites no Brasil. A mudança trazida pela perspectiva democrática, mesmo ocorrendo de forma lenta e fragmentária, pretende instituir uma escola com capacidade de integração a partir da transmissão de seu capital, mas o que se encontra é uma escola ainda muito fragilizada para enfrentar a desigualdade social. Isso fica particularmente evidente na própria relação que ela estabelece com o estudante e sua família.

\footnotetext{
${ }^{18}$ Vale registrar que em 1964 o percentual de escolarização para a população de 07 a 14 anos, no Brasil, era de $66,28 \%$. Isto significa que, em todo o território nacional, $33,72 \%$ das crianças dessa faixa etária ainda permanecia fora da escola (ROMANELLI, 1984: 82). A década de 80 caminha de forma mais intensiva e, no início dos anos 90, especificamente em 1992, a referida taxa subiu para $86,59 \%$ e $88,6 \%$ em 1993. A evolução da taxa de escolarização para a faixa 7-14 anos no período 1995 a 2007 foi a seguinte: 90,22\% (1995); 91,26\% (1996); $92,99 \%$ (1997); $94,7 \%$ (1998); 95,69\% (1999); 96,46\% (2001); 96,94\% (2002); 97,19\% (2003); 97,19\% (2004); 97,43 (2005); 97,73\% (2006); 97,67\% (2007). Fonte: IBGE, Pesquisa Nacional por Amostra de Domicílios 1992/2007.
} 


\subsection{As qualidades de sua expansão: cultura escolar como ponto de visão da relação no interior da escola}

A breve resenha do processo de expansão da escola, em que procuramos enfatizar alguns pontos acerca de seus termos, fala de uma redefinição da relação entre escola e sociedade no decorrer do século XX, principalmente no que diz respeito à condição das classes populares que, progressivamente, vai sendo modificada: a sua incorporação ao ensino é um reflexo da ampliação dos direitos sociais no Brasil. Entretanto, o direito à educação foi formalmente marcado pelo estabelecimento de "mínimos" e ofertado de maneira seletiva e desigual, tanto que medidas e leis registravam dois tipos de escola: uma profissionalizante para pobres e outra de caracter mais ampla, digamos, intelectualista, para os ricos. Com o caminhar em direção a afirmação da democracia, muito embora em meio a regimes autoritários e centralizadores no percurso, a escola, em detrimento da família e também do trabalho, passa a ser percebida como fundamental para a socialização da ampla população.

A entrada da classe popular na escola, ou a massificação da escola, produziu profundas mudanças na natureza da própria instituição escolar e, consequentemente, na qualidade de seu trabalho ${ }^{19}$. O resultado mais preocupante dessa "remodelação", do ponto de vista sociológico, é que o acesso à escola tem configurado a emergência de novas precariedades na sociedade brasileira que, de alguma maneira, representa a difícil tarefa de produzir a igualdade social no Brasil. O fato é que a realização do projeto de igualar as oportunidades na ordem social não apresenta maior envergadura porque, além de ser uma árdua trajetória, o novo processo de escolarização ofertado às classes populares, como bem mostra Peregrino (2010), veio acompanhado de circuitos que representam formas de marginalização e distinção, basta lembrarmos da segregação à qual foi submetida a escola pública com a progressiva evasão da classe média assim que ocorreu a abertura de suas portas para o mundo popular.

\footnotetext{
${ }^{19}$ Vale lembrar, a massificação escolar de que se fala é o processo de abertura da escola para uma camada antes desassistida do direito à educação escolar, que ganha contornos de maior alcance a partir da década de 1960.
} 
Esta seção pretende discutir algumas das mudanças que revelam as novas características da escola emergentes com o processo de massificação, sendo emblemática a fragilização que a acomete. Enfatiza-se, em particular, que um dos efeitos dessas mudanças se refere à forma de a escola se relacionar com o seu público que, conforme posto no capítulo dos episódios de recreio, diz respeito à dificuldade inerente à complexidade da condição social dos alunos, dos efeitos da segregação urbana e a própria tensão que permeia a relação da escola com as famílias dos alunos.

Localizando a escola pública brasileira no conjunto das instituições que fazem parte da reprodução do capitalismo contemporâneo, que engendra novas (ou o aprofundamento) desigualdades diluídas no tempo, em especial no tempo escolar, Peregrino (2010: 61/62) procura entender as formas de "recusa de escolarização" para crianças e jovens populares mesmo que a experiência escolar faça parte de suas vidas. Para a autora, de acordo com uma formulação teórica mais ampla, nas relações de produção do capital a escola tem sido um lugar de legitimação dos "excluídos em potenciais" e, nesse sentido, a escolarização perde sua finalidade de conferir um conhecimento capaz de formar o sujeito para disputas no espaço social .

À escola vem cabendo, historicamente, legitimar as desigualdades constantemente postas por esse modo de produção, selecionando o acesso aos produtos materialmente e simbolicamente produzidos. Nesse sentido, a marca do nosso tempo tem relação com o fato de que "o processo de eliminação foi adiado e diluído no tempo: e isto faz com que a instituição seja habitada a longo prazo por excluídos potenciais, vivendo as contradições e os conflitos associados a uma escolaridade sem outra finalidade que ela mesma" 20 .

A "recusa de escolarização" expõe um formato de sociedade que institui desigualdades a partir de um processo de inclusão frágil. Peregrino (2010, p. 76), argumentando com Martins (1997), enfatiza que essa maneira de inserir importantes segmentos da sociedade é especialmente revelada num jogo que, de um lado, "possui múltiplas formas de inclusão precarizada no âmbito econômico" e, de outro, uma lógica "excludente do ponto de vista social, moral e político". Esse processo ganha conotações particulares no Brasil com a forma de expansão

${ }^{20}$ BOURDIEU, 1998: 482-483. 
da escola à classe popular, em que a lenta e gradual oferta do "mínimo" representa a afirmação de privilégios (para pequenos setores da sociedade) pela afirmação dos direitos sociais (à ampla maioria). Com efeito, é com a "mutação" da função dessa instituição que o peso dessa arquitetura mostra a sua dimensão mais refinada. Vamos à explicação.

No contexto da ditadura militar, conforme Algebaile (2009), o Estado, com base no modelo tecnocrata e de modernização autoritária, realiza a reforma dos ensinos universitáro (lei 5.540/68) e de primeiro e segundo grau (lei 5.692/71), em que, de modo geral, estabelece os princípios de formação educacional para atender os interesses da produção econômica e, de modo específico, estabelece a ampliação do ensino primário obrigatório de quatro para oito anos a fim de reorientar o sistema educacional. Entretanto, no que diz respeito à análise sobre a mudança na formação escolar básica, o processo denominado de "liberação do ensino elementar" (extensão do ensino primário obrigatório) não consiste em uma efetiva incorporação dos contingentes recémchegados à escola. O fato é que a ideologia de uma "escolarização orientada para a empregabilidade" proporciona menos mudanças na estrutura social, por exemplo, via incorporação no campo do trabalho, que uma "ampliação das tarefas" da escola que exercem um deslocamento dos fins eminentemente educacionais que, a rigor, produzem sérios prejuízos à integração social.

Peregrino (2010: 90/91) afirma que um conjunto de orientações para o trabalho ocupa o espaço escolar através de "disciplinas como 'técnicas comerciais', 'artes industriais', 'educação para o lar'”, causando uma verdadeira restrição "às funções clássicas da ação escolar" a nível nacional. E, nas décadas de 1970 e 1980, essa política que confere novas funções à escola ganha contornos específicos de "gestão da pobreza", pois o Estado recupera iniciativas de programas compensatórios em termos alimentares, socioeconômicos e culturais ligados a órgãos e instituições de assistência social atuantes na década de $1940^{21}$. Assim, à escola ampliada ao mundo popular corresponde um modelo que oferta o

\footnotetext{
${ }^{21}$ A pesquisadora registra, em especial, a existência de dois programas em 1980, são eles: Programa Nacional de Ações Socioeducativas e Culturais para Populações Carentes Urbanas (Prodasec/Urbano) e o Programa Nacional de Ações Socioeducativas e Culturais para Populações Carentes Rurais (Prodasec/Rural).
} 
"mínimo" por longas décadas e, quando abre a possibilidade de a maioria da população ficar mais tempo na escola, o Estado confere um conjunto de diretrizes e práticas que desvirtua o sentido que se espera da socialização escolar: dispor o acesso a conhecimentos e habilidades que permitam a construção do sujeito e, no caso do Brasil, especialmente com a Constituição de 1988, sujeito cidadão portador de direitos capaz de atuar na consolidação da nossa democracia. Contudo, não é essa a tônica que vai se dando e que se dá, inclusive, nos anos de 1990. Pois, como sustenta Peregrino (2010), a narrativa da política educacional dos "dois mandatos de Fernando Henrique Cardoso (1994/2002) guarda continuidades em relação às políticas anteriores. Mais especificamente, ela dá continuidade à tendência apontada ao final da ditadura militar, de realizar, na expansão da escola pública para os grupos antes excluídos, a modificação do perfil institucional da escola, especialmente daquela de nível fundamental" (Idem, p. 93). Essa tendência é a perda da dimensão "escolar" concomitantemente à ampliação da dimensão "assistencial".

De modo sistematizado, com base no que acabamos de ver, podemos dizer que o processo de marginalização dos grupos populares face aos ganhos da socialização escolar, como a sua função integradora pela aquisição de conhecimentos e habilidades comuns, vai encontrar um importante reforço no período da ditadura militar, período em que a incorporação desses grupos aos sistemas escolares foi marcada por um complexo processo de introjeção de políticas sociais na escola, sendo a principal resultante dessa racionalidade o “prejuízo das funções eminentemente escolares" (PEREGRINO, 2010: 99). A perda dessas funções leva Mônica Peregrino a falar de uma condição escolar do mundo popular caracterizada por um reverso movimento encabeçado pelo Estado, e que se afirma ao longo da década de 1990, de expansão escolar sem a escola, sem o seu saber, o que ela denomina de "desescolarização da escola” (Idem).

É interessante notar que com a implementação das políticas sociais nos anos 1990 essa forma da escola vai sendo consolidada como a instituição socializadora da classe popular. Trata-se, portanto, de um fenômeno que consiste na adaptação da escola a novas funções que dão origem a uma integração à margem. Além disso, se por um lado, as escolas são usadas como estratégias do 
Estado em seus planos de ação, por outro, trata-se de uma forma precária de estar em contato com ampla maioria da população.

Em relação à década de 1990, Algebaile (2009) afirma que as mudanças institucionais da escola decorrem da vinculação entre programas de renda mínima e escolarização, articulação que foi estimulada pelo economista José Márcio Camargo ao enfatizar que os efeitos do "desemprego e do subemprego atingem mais duramente as crianças em idade escolar, obrigando-as a ingressar precocemente no trabalho para ajudar na renda da família" (p. 310). Nesse sentido, à semelhança das políticas de focalização via escola realizadas pelo regime militar, vai emergir, na formulação de políticas sociais, o uso instrumental da escola para realizar a aplicação de programas compensatórios em âmbito nacional, muito em função das vantagens operacionais.

No Brasil, após o governo federal acompanhar as iniciativas realizadas em Campinas/SP e no Distrito Federal, a articulação entre política social e escola foi consagrada pelo programa Bolsa Escola Federal ${ }^{22}$ que, criado em 1997, ganha, em 2001, projeção em toda territorialidade, devido à ampliação de recursos destinados ao programa e a flexibilidade nas regras de participação dos municípios $^{23}$. Por outro lado, exige-se dos municípios atuação ativa em sua implantação através dos recursos administrativos e de pessoal. Isto é, no estabelecimento do contrato com o governo federal, aos municípios cabia a organização de toda infraestrutura necessária à operacionalidade e efetivação do programa. Tarefas como cadastramento das famílias, informatização das fichas cadastrais e controle de frequência escolar das crianças ficaram a cargo dos municípios, especialmente das secretarias de educação (cf. ALGEBAILE, 2009).

A respeito dessa arquitetura repassada à burocracia educacional para a implementação do programa, que nos diz também de um repasse da

${ }^{22} \mathrm{O}$ Bolsa Escola se tornou o principal programa da rede de políticas sociais vinculadas à educação (cf. Algebaile (2009); Peregrino (2010).

${ }^{23}$ Antes de 2001, o programa previa a participação dos municípios através de acordo que estipulava o financiamento de $50 \%$ do valor da bolsa. Desse modo, os municípios mais pobres não conseguiam aderir à iniciativa federal. Em 2001, essa prerrogativa foi relativizada de modo que a complementação do benefício se tornou um estímulo e não uma obrigatoriedade (cf. ALGEBAILE, 2009). 
responsabilização do governo federal para o município e deste para as escolas, como que num jogo de pega e repassa, Algebaile diz o seguinte:

$\mathrm{Na}$ maioria dos municípios, a infraestrutura material e de pessoal das secretarias de educação tornou-se a principal base de operação do programa. Delas saíram as salas e o mobiliário que emergencialmente serviriam de suporte ao trabalho das equipes e à guarda de material. Delas também veio a maioria dos profissionais temporários e permanentes: componentes de equipes pedagógicas foram deslocados para coordenar as novas tarefas; escolas se tornaram postos de cadastramento; professores, funcionários administrativos e funcionários de apoio das escolas foram emprestados para realiza-lo (ALGEBAILE: 2009: 317).

Como fica claro na nota acima, um conjunto de atividades administrativas e humanas encharcou a área educacional com finalidades estranhas às diretrizes de seu mundo, uma vez que os governos municipais subordinaram as equipes pedagógicas e a burocracia escolar ao programa social; por sua vez, essas ações despotencializaram a atuação nas demandas e necessidades escolares levando as escolas à fragilização de seu perfil institucional (cf. ALGEBAILE, 2009; PEREGRINO, 2010) que, emblematicamente, em nível micro, revela-se na improvisação das práticas pedagógicas e, em nível macro, num formato "minimalista" (CAVALIERE, 2009) que caracteriza o campo escolar, como veremos mais a frente.

A fragilidade institucional não ocorreu somente pelo conjunto de tarefas administrativas do programa conferido à escola, mas também porque, conforme previsto em acordo regulamentado, foram criadas ações socioeducativas, compreendidas como ações "de apoio aos trabalhos escolares, de alimentação e de práticas desportivas e culturais em horário complementar ao das aulas" (cf. ALGEBAILE, 2009: 316), que, similares à tendência de programas do final da ditatura militar (cf. PEREGRINO, 2010), levaram para dentro das escolas necessidades sociais. Isto é, as ações socioeducativas na tarefa de dar suporte à permanência escolar das crianças beneficiárias do programa operaram uma "transmutação", involuntariamente ou não, de problemas sociais mais amplos em problemas de educação. Conforme Algebaile (2009, p. 319), a iniciativa das ações socioeducativas acabou "transferindo, para um plano cognitivo, afetivo, moral e comportamental, problemas estruturais cuja produção (e enfrentamento) se dava no plano político-econômico". 
Então, a escola se tornou um lugar de disputa entre a escolarização e a política pública não escolar. Nessa armadilha, a escola é capturada como meio para a resolução de problemas que fogem à sua natureza institucional, evidenciando uma regularidade no retardamento do Estado brasileiro de assegurar a integração e a equidade social ao simplesmente desconfigurar a escolarização no seu próprio espaço, diríamos: uma marginalização por dentro.

É através desses termos que a década de noventa reafirma a oferta de uma "escola pobre para os pobres". O curioso é que essas mudanças acontecem quando o mundo popular ingressa, massivamente, na escola (cf. PEREGRINO, 2010). A esse movimento, acrescenta-se um processo de precarização das unidades escolares nas dimensões do espaço físico, nas condições de trabalho e, até mesmo, na formação de pessoal. Há, portanto, uma convergência entre as práticas de marginalização, inserção frágil na esfera pública; do saber escolar, precarizado pela dimensão assistencialista; e da condição social dos pobres, que acessa os direitos pela tangente, isto é, pelo "mínimo". Com efeito, ao ganhar esse formato, o Estado brasileiro mais uma vez atua de modo a condicionar novos processos de retardamento da equidade social.

Para Ana Maria Cavaliere (2009), esse quadro assume caracterizações de uma "escola minimalista", que diz respeito às dificuldades com as quais as instituições escolares lidam diariamente como a falta de espaço, falta de material, falta de profissionais e condições adequadas para a equipe pedagógica e seus alunos. O fato é que, com a chegada da classe popular, o trabalho de socialização escolar ficou mais complexo muito em função do baixo investimento e da forma de expansão da escola que não deixa de remeter, como vimos, a um processo de seu enfraquecimento pelo próprio Estado.

O Estado ainda usa a estrutura escolar na sua tarefa de ofertar políticas sociais e um dos motivos para que isso ocorra, de acordo com Cavaliere, é o mérito de a escola ser a principal instituição com maior presença em todo o território nacional.

A despeito de todas as críticas, pertinentes ou não, a importância da escola para a sociedade brasileira fica evidente quando se observa que quase todos os programas sociais desenvolvidos por diferentes governos, 
muitos dos quais vieram a se fundir no atual Programa Bolsa Família, passam por ela. Isso por que sua capilaridade é única entre todas as demais instituições, públicas ou particulares. Mesmo as organizações de comunicação de massa, principalmente cadeias de televisão e rádio, e algumas organizações religiosas, que têm grande alcance em todo o País, não estabelecem com a população a relação orgânica, pessoal e duradoura, tal como o faz a escola. Num país de imenso território, como o Brasil, o Estado se faz presente por meio dela de maneira mais eficaz (CAVALIERE, 2009: 56).

Com efeito, ao atuar via escola o Estado parece não reconhecer os limites dessa instituição na tarefa de socializar a classe popular às habilidades e aos conhecimentos que contribuem para realizar os princípios lhes conferidos: forjar o sujeito cidadão para a democracia e qualificado para o trabalho (cf. LDB, 1996). $\mathrm{Na}$ verdade, a política social que utiliza a capacidade escolar ajuda a configurar os aspectos da "escola minimalista", uma vez que o desenvolvimento do trabalho eminentemente escolar ocorre em um ambiente saturado de tarefas impostas por gestores de políticas públicas.

É evidente que em um quadro desse o desafio de atrair o aluno popular às questões escolares se torna ainda maior. Pois essa relação entre escola e mundo popular não é uma relação desprovida de tensões, pelo contrário, são formas socializadoras que, com o processo de universalização da formação escolar, foram postas em contato, mas a interação depende de mais motivações. Desse modo, quer-se dizer que a fragilidade à qual submeteram a instituição escolar se revela mais assustadoramente frágil no desafio de a escola criar pontes com o seu público. Então, as demandas conferidas à escola pública pela Constituição de 88 , bem como as expectativas da sociedade face ao trabalho de aprendizagem no educando, por exemplo, como o da linguagem escrita e do cálculo, mas também da cidadania, tornam-se ainda mais complexas se somada, a esse quadro de fragilidade institucional descrito agora pouco, a interação do desencontro que permeia as práticas entre a cultura escolar e a cultura do mundo do aluno.

Para Cavaliere o desencontro entre a escola e a classe popular existe porque são dois processos de socialização distintos:

As formas de socialização das classes populares ainda contam com o trabalho juvenil em diversas modalidades e, ao lado dele, com um tipo de formação que induz muito cedo o adolescente e o jovem à autonomia. A 
tutela, típica da ação escolar, é algo que incomoda particularmente ao jovem de classe popular, que, em geral, adquire mais cedo sua independência de locomoção e autocuidados. A escola, empobrecida e burocratizada, que tutela, mas não oferece algo desafiador, acaba sendo intolerável para uma parte desses jovens, perdendo-os para outros chamamentos da vida cotidiana (CAVALIERE, 2009: 57).

O conflito entre essas duas formas socializadoras revela que, com a massificação da oferta do ensino, a escola passou a lidar com um público que coloca em tensão a própria construção social do aluno e, especialmente nas escolas de ensino fundamental, da família pedagógica, aquela convocada a se tornar coautora da socialização escolar. O trecho de Cavaliere (2009) chama atenção para a dimensão desse problema que, a nosso ver, parece ser um dos mais desafiadores do processo de universalização da escola no Brasil: o diálogo entre a escola e o mundo do aluno. Pois, desde que o mundo popular chegou à escola, pesquisas têm enfatizado as formas assimétricas da relação entre escola (pública) e seu público (popular) que são promotoras mesmo de desigualdades sociais.

Mas essa questão não é uma realidade apenas do Brasil. Nas escolas públicas portuguesas, por exemplo, essa problemática é pensada por Pedro Silva (2003) através da relação entre a escola e a família, que, para ele, é essencialmente uma relação entre culturas. Silva (2003, p. 356) assinala que a cultura oficial da escola é "urbana, letrada, teoricista e abstratizante, de classe média, adultocêntrica, androcêntrica, lusa e católica" ${ }^{24}$, ao passo que a cultura ou culturas locais, pertencentes aos diferentes grupos da sociedade, em especial a cultura periférica, está em descompasso com a cultura escolar. Desse modo, a cultura escolar estaria em conformidade com a cultura de alunos e famílias provenientes de meios com as características valorizadas pela instituição, e em desconformidade com a cultura de alunos oriundos de meios populares.

Contudo, segundo Silva, a relação escola e família está longe de se situar como uma questão isolada ao ambiente escolar:

Ela [essa relação] se situa na encruzilhada do macro com o microssociológico. Ela remete simultaneamente para a relação escola-

\footnotetext{
${ }^{24}$ Essa cultura oficial, referida pelo autor para pensar o caso português, tem como porta-voz a instituição escolar que, em função da cultura nacional, simboliza uma dificuldade de aproximação com as culturas dos alunos. Para entender a sua reflexão sobre interculturalidade ver o capítulo 06.
} 
sociedade e para o papel (regulador) do Estado nesta articulação, assim como para o entendimento do que se passa a nível (do) local, ou seja, o que se passa em cada escola e como se relaciona esta com a comunidade (ou comunidades) com que interage. Por outras palavras, significa (re)pensar a própria definição da escola, o que passa por entender quem são os protagonistas (atuais) da questão escolar (SILVA, 2003: 20).

Duas questões pontuadas por Silva (2003) são fundamentais à reflexão que estamos desenvolvendo neste capítulo. A primeira é que pela dinâmica da relação escola e família é possível falar do lugar da escola na regulação social dos pobres. Ao imprimir em sua prática político-pedagógica os elementos da cultura "branca, masculina e heterossexual" (Idem, p.79), claros elementos de representação da cultura dominante, a escola tende a estabelecer uma relação mais fragilizada com os grupos de indivíduos que trazem a marca cultural de uma diversidade que a desafia. Nessa relação entre culturas, segundo Silva, podem ocorrer duas formas de desfecho no espaço escolar: uma de confronto (quando há baixa comunicação entre cultura escolar e cultura dos alunos) e outra de conflito ou choque cultural (quando a descontinuidade entre as culturas é total).

A segunda questão é um aprofundamento da primeira. Isto é, trata-se do desafio das instituições escolares estabelecerem pontes com a diversidade cultural dos discentes, percorrendo justamente a possibilidade de diálogo como forma de evitar "barrar na porta de entrada da escola" a cultura dos alunos, evidente sinal não de uma negação, mas de um afastamento. $O$ fato é que, conforme Pedro Silva (2003), a cultura periférica (da família e dos alunos) passa por um processo de diminuição quando entra em contato com a cultura escolar, fato que se verifica na desqualificação do modo como educam seus filhos, como se vestem ou mesmo como convivem.

Entendemos que, no caso das escolas brasileiras, é preciso relativizar a força desta cultura escolar assinalada por Silva (2003), que sinaliza para algo prédeterminado. Pois, como vimos, no Brasil, a entrada dos pobres na escola pública foi acompanhada por um processo de precarização que afeta, entre outras coisas, a sua institucionalidade e, portanto, a força com que ela se impõe dentro de seus muros. Além disso, diferentemente das escolas portuguesas, nas quais o multiculturalismo está muito presente, o que está em jogo na escola brasileira é a 
relação com a família e os alunos pobres, em especial os pobres das favelas - no caso dos grandes centros urbanos.

Aqui, no Brasil, parecem predominar percepções que de alguma maneira estabelecem um estrutural distanciamento dos profissionais da escola em relação ao público que eles atendem. Ao entrevistar professores que lidam com alunos moradores de favelas cariocas, Telles (2009) ressalta que boa parte dos entrevistados considera a família nuclear como modelo de família estruturada, e quando esses professores se deparam com famílias de formato fugidio do padrão conhecido por eles a reação é a de que elas são um tormento para o projeto da escola. E, em relação ao estudante, Telles (Idem) mostra que boa parte dos professores ouvidos na pesquisa atribui a dificuldade no processo de ensinoaprendizagem à baixa motivação e ao baixo valor à escola conferido por esse aluno. Ou seja, transfere a responsabilidade do sucesso/fracasso escolar para o estudante.

Nas conclusões de sua pesquisa, Telles (2009) enfatiza que essa desqualificação do estudante está carregada de preconceitos, os quais são fortalecidos por um distanciamento do professor em relação ao seu aluno e ao seu universo. $\mathrm{O}$ fato é que, decorrente do histórico processo de marginalização que acompanhou a redefinição dos espaços da cidade do Rio de Janeiro, a realidade de vida desses estudantes ainda é algo obscura; em relação à família predomina uma perspectiva negativa fruto dos seus arranjos, conforme destaca Telles: com a pouca duração dos relacionamentos afetivos, muitas vezes os entrevistados [professores] afirmavam que a criança estaria sendo indevidamente cuidada pelos avós ou parentes afins, não percebendo que novos arranjos familiares podem ser legítimos e satisfatórios (p. 159).

Pois bem, o caso brasileiro é esse onde a escola se tornou central na vida das crianças e adolescentes populares, e onde também a comunicação entre os dois polos se revela como um dos principais desafios na relação, truncada, da escola e seu público. Apesar de não ser exclusivo, um fato relevante é que na escola não deixa de existir os aspectos negativos da ecologia do lugar de moradia dos alunos e de suas famílias. 
Por outro lado, ao realizar uma pesquisa quantitativa ${ }^{25}$, Marcelo Burgos (2012) identifica que a família popular demonstra forte interesse por mais escola na vida de seus filhos e, sendo assim, a questão é tentar entender "por que as escolas, ainda que em diferentes graus, seguem se mostrando pouco confiante na possibilidade de mobilizar as famílias" (p. 1045) e, por extensão, a cultura do aluno no que diz respeito ao seu mundo. Para Burgos (2012) esse problema é inerente aos termos estabelecidos entre a escola pública e o meio popular, cujo padrão é "assimétrico e frequentemente paternalista" (p. 1015).

Ao aprofundar essa questão, Burgos (2012) procura compreendê-la para além do estereótipo e sugere a hipótese de que a qualidade da relação, bastante "assimétrica e frequentemente paternalista", também tem a ver com o contexto que precedeu a reafirmação dos princípios democráticos em 1988. Isto é, no momento em que ocorre a massificação escolar o regime autoritário, ao estipular a política educacional que valoriza as "culturas profissionais" - forjadas pela pedagogia tecnocrata -, imprime no ambiente escolar toda a cultura marcada pelo autoritarismo no meio social. Assim, nessa "massificação autoritária", termo que remete a uma ideia de escola como instrumento da tecnocracia, Burgos (idem: 1045) supõe que é por isso mesmo que a escola "têm muita resistência em lidar com seu público segundo um padrão de igualdade e de equidade", e isso compromete ainda a possibilidade da escola perceber que a família está a fim de jogar o jogo, bem como valorizar elementos do mundo do aluno no seu cotidiano.

Apesar de levantar essa hipótese para entender a relação assimétrica da escola com seu aluno, o pesquisador afirma que é preciso ter cautela, pois pode facilmente cair na "armadilha da responsabilização da escola pelo problema": a relação entre professores, alunos e famílias é também um problema da dificuldade de fazer valer os princípios de nossa democracia. É certo que, conforme Burgos,

\footnotetext{
${ }^{25}$ A pesquisa entrevistou 320 pais/responsáveis de estudantes de escolas públicas de ensino fundamental, situadas na Gávea - bairro nobre da cidade do Rio de Janeiro, ao longo de 2010, sendo que a ampla maioria dos entrevistados era moradora da Rocinha $(85 \%)$. Nessa pesquisa tive a oportunidade de coordenar o campo que, efetivamente, consistiu em um enorme aprendizado. Vale dizer que foi parte das atividades realizadas pelo projeto Gestão Escolar e Territórios Populares, coordenado pelos professores Marcelo Burgos e Ralph Bannell, e que envolveu uma equipe de 30 estudantes de graduação e pós-graduação da PUC-Rio. Uma parte dos dados, bem como uma reflexão da escola pública a partir desses dados, encontra-se sistematizada em Revista Dados, 2012, vol. 54 n 4 .
} 
"tudo indica que ela tem, de fato, parcela da responsabilidade, mas o fenômeno é bem mais complexo, demandando que se considere a relação da escola com outras esferas do mundo da vida em cada contexto específico" (BURGOS, 2012: 1045).

$\mathrm{O}$ nosso percurso até aqui consiste na tentativa de responder à questão colocada no início do capítulo e reafirmada no início desta seção: qual tem sido o sentido da escola brasileira: ou, ela tem criado um ambiente para ensinar e educar? Com base nos textos mobilizados estamos acordando que o sentido e a realização da escola para os pobres tem se dado com o incremento de políticas sociais que se apropriaram da instituição escolar (cf. ALGEBAILE, 2009), fragilizando-a naquilo que é "eminentemente escolar" e transformando-a num lugar menos de socialização escolar que da gestão da pobreza (cf. PEREGRINO, 2010). E, nesse quadro mais geral de "escola minimalista" (cf. CAVALIERE, 2009) e de "massificação autoritária" (BURGOS, 2012), o que está em jogo é a redefinição dos termos da relação entre a escola e o seu público, de modo específico entre os profissionais da escola e seus alunos, bem como na relação com a família e o mundo desses alunos com vistas à criação de um ambiente que esteja a favor da instrução e da educação. Em síntese: o que está em jogo é a dificuldade de a escola lidar com esse público popular, que, no caso dos episódios de recreio, em sua maioria são alunos moradores de favelas cariocas.

De certo modo, a dificuldade de construir uma socialização escolar forte no Brasil está ancorada nos limites dessa instituição, que ainda não sabe lidar com as caracterizações do mundo das crianças e adolescentes populares. No entanto, e embora saibamos que a trajetória de afirmação da escola pública para o segmento mais pobre da população evidencia uma fragilização do projeto republicano, não podemos perder de vista a capacidade da instituição escolar de alimentar uma interação com seu público a fim de tornar a experiência do mundo popular uma potencialidade para a socialização escolar. Com efeito, cabe à escola ser guardiã de um conjunto de práticas que institucionalize uma maior aproximação com os seus alunos de modo a não se tornar seletiva, chancelando a desigualdade existente na sociedade brasileira. 
Vale ressaltar que essa aproximação com o mundo do aluno não é apenas uma estratégia pedagógica, mas uma forma de construir um ambiente em que o estudante é entendido como sujeito de direito. Então, como se vê, trata-se de uma cultura escolar que firma o pacto democrático com o mundo popular nas interações específicas, por exemplo, entre professor e aluno, escola e família. Em uma frase, construir uma cultura escolar atenta ao mundo do aluno é encarar esse aluno como sujeito de direito, cuja finalidade explícita consiste em trabalhar uma socialização escolar para o fortalecimento da sociedade democrática.

A seguir são apresentados episódios de recreio que registram particularidades de como a escola se relaciona com o aluno e seu mundo. Vale dizer que o recreio é uma parte importante da rotina escolar e a sua dinâmica pode ser reveladora de indicadores da dinâmica geral da escola. Pelo recreio podemos acessar a capacidade da escola desenvolver a habilidade de lidar com a cultura do aluno. A nossa pesquisa, apesar de ter algumas limitações, aponta para importantes indícios a respeito desse desafio. 


\section{Episódios de recreio}

"Na verdade, é a natureza dos fatos que estudamos que nos incita a distinguir, neles, o que pertence à estrutura, e o que pertence ao evento" (Lévi-Strauss, 1970, p. 61).

\subsection{Recreio: espaço-tempo visto por episódios}

A proposta deste capítulo é apresentar parte da etnografia realizada em recreios de escolas públicas de ensino fundamental a fim de estimular, de modo específico, uma compreensão da relação estabelecida entre a escola e os seus alunos. O sentido de relação envolve as práticas que se desenvolvem no espaçotempo da escola, e o nosso intuito não é apenas reconstruí-las, mas principalmente buscar enxergar nas situações apresentadas as possibilidades e os limites que circunscrevem os atores escolares na afirmação dos princípios educacionais. Nossa preocupação mais geral é a de extrair elementos que possam subsidiar uma reflexão do processo de socialização escolar de crianças e adolescentes das classes populares por uma instituição que tem passado por profundas mudanças com a sua expansão.

No que se refere especificamente à forma de trazer a empiria que fala dessas idas e vindas às escolas, mobilizamos a noção de episódio para compartilhar algumas situações de campo e, a fim de problematizar o que será apresentado, faz-se necessário entendê-los não pela sua significação eventual, pouco corriqueiro, mas por uma leitura que confere importância aos elementos de uma dinâmica de interação permeada pela realidade estrutural da escola pública brasileira. Isto é, através das dinâmicas apresentadas pelos episódios é possível pensar sobre a própria instituição escolar e a tensão forjada pelas diferentes 
posições assumidas por professores e alunos. Portanto, apoiando-nos na epígrafe de Lévi-Strauss (1970), que alerta para a importância de enxergar a natureza dos fatos, é possível verificar nos episódios elementos que dizem respeito à forma dessa escola, a maneira como o recreio é percebido pela gestão escolar e, mais especificamente, às substâncias de uma relação entre profissionais e alunos que vem sendo construída no interior da nossa escola pública.

De nossa parte, do ponto de vista do lugar no qual se situam os episódios, o recreio é tomado como um importante espaço-tempo escolar para compreender as formas de a escola encarar seus alunos que, por sua vez, trazem um conjunto de múltiplas referências de seu mundo. Vale dizer, porém, que neste trabalho não será feita uma discussão sobre o recreio; reconhecemos a importância desse espaço-tempo escolar como um importante lugar para enxergar tensões inerentes à escola pública, especificamente para observar a forma de a escola lidar com seus alunos. Por outro lado, sabemos que não é fácil administrar esse momento da rotina escolar e, de modo especial, consolidá-lo como algo que jogue a favor do processo de ensino-aprendizagem e da socialização escolar da qual depende um tipo particular de cidadania, aquela forjada por princípios democráticos presentes na escola. Se quisermos problematizar essa questão, nossa reflexão nos leva a dizer que uma dimensão relevante é o próprio lugar que o recreio ocupa em face da escola. Como a escola entende o recreio? Existe um momento para se pensar o recreio? A escola conversa com os alunos sobre as regras do recreio? Como essas regras são sancionadas e exercidas? Por outro lado, como os alunos experimentam esse momento da escola? Perguntas como essas ajudam a entender os vários sentidos que estão por trás desse espaço-tempo de toda instituição escolar, como também colaboram para pensar, pela via relacional (entre escola e seu público), a complexidade da escola pública brasileira de escolarizar o mundo popular.

Acontece que na dinâmica do recreio estão expostos elementos de uma relação que está sendo construída a duras penas, conforme veremos, basicamente por contar com a ausência de um padrão de comunicação que remete à dificuldade de fixar papeis escolares no interior dessa instituição. Quer dizer, com isso, que o estudante da nossa escola pública é representado mais pelos efeitos da classe social a que pertence, bem como pelo seu local de moradia, do que propriamente 
pelo papel a ser desenvolvido na escola - o papel de estudante. Essa questão diz respeito à dificuldade de valorizar as diferenciações relativas às segmentações sociais, passo importante na prática pedagógica contemporânea, e quando isso não ocorre é mais complicado se aproximar do mundo dos alunos, pois a prática escolar pode cair no risco de ser pautada pelos efeitos e representações sociais negativas, prejudicando as interações no âmbito do processo de ensinoaprendizagem. Atuando com base em representações que desqualificam o estudante, a escola exerce uma forma institucional que contribui para uma ligação frágil com o seu projeto os indivíduos de condição social popularizada.

Seguindo esse raciocínio, o esforço aqui adotado é aquele que procura mostrar a complexidade do que está em jogo na relação com o aluno da favela que, como será possível ver com os episódios, possui mais marcas da informalidade que da institucionalidade. Os episódios apresentam dinâmicas que apontam nuances de como a escola representa o aluno, uma representação que encontra fortes elementos da caracterização negativa que a favela ganhou ao longo de sua história. Com base nos episódios, na escola parece predominar uma convergência entre o senso comum acerca da sociabilidade na favela e o que de pior dela há no aluno - que leva para dentro da escola. Com efeito, o encontro entre a cultura do aluno e a cultura da escola se dá com base nessa fronteira de pertenças: os alunos à favela, na sua vertente estereotipada; os professores a um mundo diferente e superior.

A seguir apresento alguns episódios do conjunto de observações realizadas no recreio escolar de quatro escolas públicas de Ensino Fundamental da cidade do Rio de Janeiro. A proposta aqui consiste em compartilhar alguns episódios e não explorar completamente toda a dinâmica observada com as incursões realizadas ${ }^{26}$. Além disso, para fins metodológicos, vale dizer que as incursões foram feitas coletivamente e o nosso intuito não foi realizar uma etnografia strictu sensu a fim de detalhar cuidadosamente a riqueza de um campo social em análise. Portanto,

\footnotetext{
${ }^{26}$ Essas incursões etnográficas, das quais participei, são frutos de um processo coletivo de investigação realizado no decorrer de dois meses no ano de 2012. Para montar este capítulo, apropriei-me das anotações de campo dos seguintes pesquisadores: Ana Carolina Canegal, Bernardo Trigueiro, Fernanda Antunes, Gabriel de Melo Borba, Laura Rossi e Mariana Junqueira. Agradeço-lhes pela concessão do uso do material.
} 
apesar de termos adotado a estratégia de observação participante, aqueles que lerem este trabalho com olhares mais ancorado na antropologia irão encontrar uma série de limitações de campo. Mas faço a lembrança de que a nossa preocupação central era explorar a dinâmica do recreio de escolas ${ }^{27}$ que lidam com moradores de favelas: três escolas estão situadas no bairro da Gávea e uma na favela da Rocinha; todas atendem, majoritariamente, estudantes que vivem nesta favela.

\subsection{Eixo da prática: episódios de recreio}

\subsubsection{Primeiro episódio - escola 01: o funk no recreio}

Antes de falar do episódio é importante dizer que a escola, aqui chamada de escola 01, atende pouco menos de 500 alunos distribuídos em turmas do segundo segmento nos dois turnos escolares, sendo o período da manhã de 07:30 às 12:30 e o da tarde de 13:00 às 17:30. Essa escola está situada no bairro da Gávea, lugar que concentrar residências de famílias cujos capitais social, econômico e cultural simbolizam um contexto urbano de elite da cidade. No seu entorno, porém, existe uma das maiores favelas da América Latina, a Rocinha, e os estudantes dessa escola fazem parte da realidade dessa favela: de acordo com os dados do Sistema de Controle Acadêmico ( $\mathrm{SCA}^{28}$, 2012), cerca de $80 \%$ dos alunos são moradores da Rocinha e menos de 10\% da Vila Parque da Cidade, uma pequena favela localizada na parte alta do bairro da Gávea ao lado do Parque Natural Municipal da Cidade do Rio de Janeiro.

Sem entrar em relatos mais detalhistas, importa ainda falar que as dinâmicas do recreio da escola 01 se desenvolvem em três espaços: no refeitório,

\footnotetext{
${ }^{27}$ São escolas do primeiro e do segundo segmento do Ensino Fundamental, sendo duas atendendo entre 300 e 500 alunos e duas entre 700 e 1200 estudantes.

${ }^{28}$ O SCA é um sistema informatizado criado pela Secretaria Municipal de Educação do Rio de Janeiro para as escolas usarem no processo de registro de matrículas dos alunos. Esse sistema arquiva as informações colhidas pela ficha branca. Isto é, o processo de matrícula nas escolas municipais do Rio de Janeiro é composto de dois momentos: o primeiro registra dados do aluno e seu responsável em uma ficha denominada pela escola de "ficha branca"; o segundo é a passagem dessas informações para o sistema informatizado, o Sistema de Controle Acadêmico.
} 
na parte da frente da escola (entre o portão de entrada, que estabelece a fronteira com a rua, e a porta do refeitório), e na pequena área entre o muro (fronteira com residência) e o prédio - a área lateral da escola. Os seus alunos precisam dividir o espaço com os mobiliários como cadeiras e mesas de cimento, dois aparelhos de ferro afixados ao chão para o exercício físico na modalidade "barra", uma velha mesa de madeira para o jogo de totó, duas mesas de cimento para o jogo de pingpong e um bebedouro, que fica no refeitório próximo aos banheiros.

Uma característica importante observada é a forte presença de adultos fiscalizando o recreio, e, segundo eles próprios, são responsáveis pela integridade dos alunos e da instituição escolar, conforme evidencia a preocupação de um deles: "Aqui é mais tranquilo, mesmo assim se a gente não observar isso aqui pode ficar uma loucura". Portanto, os espaços do recreio servem de palco para a dinâmica não apenas protagonizada por alunos, mas também por profissionais da escola, como porteiro, professor, agente escolar, diretora-adjunta e, inclusive, a diretora.

O episódio aconteceu na área lateral, onde ficam as duas mesas do jogo de ping-pong, os aparelhos para exercício muscular e três bancos de cimento. No momento da observação, um grupo de alunos jogava tênis de mesa e outros estudantes permaneciam sentados nos bancos conversando sobre algumas experiências. Um desses grupos falou sobre o final de semana - o dia da observação era uma manhã de segunda-feira. Esse grupo era formado de estudantes com mais idades, acho que uns 13/14 anos. Não dá para afirmar ao certo a idade dos estudantes porque ficou decidido que só conversaríamos com eles se algum tivesse interessado em se comunicar conosco. De fato, a nossa função era observar o que acontecia para compreender a dinâmica escolar e suas regras de convivência nesse espaço-tempo específico da rotina da escola, que é o recreio.

Meninas e meninos mencionaram o baile funk como algo que tinha sido legal no final de semana. O baile de funk aconteceu em alguma das 28 localidades da Rocinha e os estudantes falaram com entusiasmo do evento. Alguns estudantes, especialmente as meninas, gesticularam o ritmo musical timidamente em referência ao que tinham feito no baile, mas não chegaram a desenvolver os 
famosos "passinhos" que caracterizam a dança. Na conversa sobre o baile e sua música não apareceu nenhuma exaltação à arma, ao crime ou às drogas como enfatizam os chamados funks "proibidões", muito frequentes em bailes de favelas marcados por alguma facção criminosa. Surpreendentemente surge uma caixinha de som nas mãos de um aluno que veio do outro lado da área, onde acontecia o jogo de ping-pong, e esse mesmo aluno se inseriu no meio das meninas que estavam apertadas no pequeno banco de pedra. O estudante colocou a caixinha debaixo do banco, rodeado por alguns colegas que estavam em pé. Apesar de haver uma supervisora nessa área, bem como a diretora adjunta ter chegado para conversar com a supervisora como se estivesse perguntando: "tá tudo bem por aqui?", o aluno não se intimidou e deu play na batida do funk que seguiu seu ritmo até a diretora chegar. Quando a diretora chegou o funk parou; após sua saída, o funk retornou.

\subsubsection{Segundo episódio - escola 02: o boné e o papel higiênico}

Essa escola também está localizada no bairro da Gávea e funciona no diurno. Seu porte pode ser considerado grande, pois atende mais de mil alunos distribuídos em dois segmentos escolares, o primeiro até o $5^{\circ}$ ano e o segundo entre o $6^{\circ}$ e o $9^{\circ}$ ano. Desses estudantes, cerca de $90 \%$ moram na favela da Rocinha (cf. SCA, 2012) e os outros $10 \%$ espalhados nos bairros da Gávea e Leblon, como também nas favelas do Vidigal e Parque da Cidade. Os que moram na Gávea e no Leblon são filhos de funcionários dos prédios desses bairros.

$\mathrm{O}$ recreio desta escola acontece na área externa e interna do prédio. $\mathrm{Na}$ área externa, os espaços usados pelos alunos são a quadra, uma rampa levemente inclinada que dá acesso à garagem da escola e um pequeno pátio que separa a rampa e a quadra. Na parte interna, a dinâmica do recreio se desenrola nos três andares que constituem a escola: a maioria dos estudantes se concentra no primeiro andar, onde tem o refeitório e o rádio da escola; o segundo andar é aproveitado por alguns alunos que ficam nos corredores das salas de aula, de professores e da direção; outros alunos, de maior idade, utilizam o terceiro andar 
da escola que, segundo a observação, é um espaço mais reservado, senão exclusivo, para namoros.

No recreio da escola 02 quase não se vê adultos acompanhando o que acontece nos corredores, no pátio e, menos ainda, no terceiro andar. Ao que se percebe, é que a sociabilidade e seus conflitos são regulados pelos próprios alunos.

\section{Caso do boné}

Era o recreio de uma manhã e entre jogos, brincadeiras e conversas dos estudantes aconteceu um episódio que chamou mais atenção. O caso envolvia um adolescente que aparentava ter 15 anos e um professor de Educação Física, que falava firme com o estudante a fim de fazer valer o que, talvez, fosse uma regra. O professor exigia do aluno que tirasse o boné, mas afirmando não ser o único que estava com esse adereço na cabeça o estudante contrariou o professor a ponto de este tentar tomar à força o boné do jovem. O estudante resolve, então, tirar por ele mesmo o boné, mas não entrega ao professor, que desta vez tentava pegar de suas mãos. Sem sucesso e no meio do recreio, com outros alunos vendo aquilo tudo acontecer, a situação ficou mais tensa com o fato de o professor querer usar mais de sua autoridade, passando a falar mais alto e apontando para o boné na tentativa, frustrada, de pegá-lo das mãos do aluno. O aluno, por sua vez, retrucava com palavrões e dizia que não fazia sentido o professor exigir apenas o seu, já que outros estudantes também estavam com boné. Contrariado e percebendo que não iria conseguir fazer valer sua autoridade, fazendo com que o estudante lhe entregasse o boné, o professor resolve ir até a direção a fim de relatar o ocorrido e, provavelmente, exigir alguma providência para a desobediência do aluno.

A pesquisadora não acompanhou o professor, ficou no pátio, mas também precisou de pouco tempo para ver o professor voltar. É que a diretora não estava na escola e o professor desceu as escadas que levam ao pátio, no primeiro andar, e 
não se dirigiu ao estudante. $\mathrm{O}$ caso ficou por isso mesmo, não tendo sido observada nenhuma providência naquele momento do recreio.

\section{Caso do papel higiênico}

Este episódio foi observado no recreio da tarde em dia diferente do episódio acima, mas é na mesma escola e trata de breves conversas sobre um problema bem específico. Primeiramente, o caso envolve duas meninas que conversam entre si sobre o banheiro feminino; em segundo, a cena é figurada por uma aluna que faz uma crítica à escola para a pesquisadora. Uma terceira conversa registra um aluno trocando duas frases com a diretora, coincidentemente, em relação a mesma queixa das meninas.

$\mathrm{Na}$ descida do segundo para o primeiro andar duas meninas reclamavam de algumas coisas na escola, segundo a fala delas, a direção da escola mostra falta de preocupação com a preservação da intimidade das alunas no banheiro e faz pouco esforço para mudar a precária situação deste ambiente. "Esses menino são tudo safado, fica olhando dentro do banheiro (sic), quero ver se for olhar lá no banheiro da 'rainha' (diretora) o que ela vai fazer." A queixa foi colocada em forma de comparação com a situação da diretora, que parece sustentar uma realidade muito desigual entre ela e seus alunos. Não à toa, a diretora é apelidada de "rainha" pelas alunas. A fala capturada na observação deixa claro esse tom presente na queixa dessas estudantes:

Nós fica tudo largada aqui nessa escola (sic), bebedouro com água quente, e ela lá em cima com água geladinha; banheiro sem papel [higiênico], sem sabonete, sem descarga e a 'rainha' lá com tudo ajeitadinho... num fode (sic)".

Nessa mesma tarde, um carregamento de papel higiênico chega à escola e uma aluna com seus 13-14 anos comenta com a pesquisadora: "não sei pra quê tanto papel higienico se no nosso banheiro não tem nenhum”. Apontando para um lugar próximo ao pilotis do primeiro andar que serve para guardar rolos desse papel conclui dizendo que "o rolo fica ali pegando bactéria". A diretora chega 
para dar ordens aos entregadores de onde deve ser posto o papel e, nesse momento, um breve diálogo é estabelecido entre discente, dessa vez um aluno, e diretora.

- o aluno diz à diretora: "Não sei o quê cês fazem com esses papel tudo".

- prontamente a diretora responde: "Esses papel tudo o quê garoto, fala direito... vocês não sabem usar o papel, entopem o vaso, tem que se limpar é com jornal!’”.

E a conversa é finalizada com a diretora batendo na bunda do estudante com um bloco de folhas e ordenando que suba para sua sala.

\subsubsection{Terceiro Episódio - escola 03: da educação física à sala de aula}

A escola cujo episódio será relatado atende alunos do primeiro segmento ( $1^{\mathrm{o}}$ ao $5^{\mathrm{o}}$ ano), localiza-se em ponto estratégico do bairro da Gávea. A quantidade de estudantes dessa escola está entre 300 e 400; são alunos que têm entre 6 a 11 anos de idade, estudam nos dois turnos escolares e, de acordo com o Sistema de Controle Acadêmico (2012), entre $80 \%$ e 90\% deles residem nas favelas Rocinha e Parque da Cidade.

É uma escola de pequeno porte e o recreio acontece no pátio central. Esse pátio é rodeado por salas de aula e da direção e não comporta todos os estudantes em um mesmo recreio, tanto que há um sistema fracionado de ano escolar: a cada 15 minutos tem-se o recreio de um ano escolar diferente. Em dias de aula de Educação Física o pátio é divido por bancos para evitar que uma atividade se misture a outra. Nesses dias, concomitantemente, enquanto alguns têm aula de Educação Física, outros estudantes vão para o recreio e uns terceiros ficam na sala de aula.

O episódio aconteceu em um desses dias de aula da Educação Física, numa terça pela manhã de Outubro de 2012. Os alunos estavam sendo conduzidos para a 
sala de aula por sua professora, um deles é chamado atenção e, apontando para a pesquisadora, a professora fala algo para o aluno do tipo: "ela está olhando!". Antes disso, ainda no momento que ministrava a aula de educação física, a professora tentava separar a sua aula da atividade do recreio, que também se desenvolvia no pátio, a fim de evitar que alguns alunos invadissem o espaço de sua turma. A educação física terminou e ao levar seus alunos de volta para a sala de aula a professora se aproximou da pesquisadora perguntando se era da PUC e disse que desenvolvia alguns projetos paralelos. A professora, então, numa conversa um pouco confusa, tentou explicar esses projetos a fim de envolver a pesquisadora e já pedia os seus dados pessoais. Ao mesmo tempo em que fazia perguntas à pesquisadora a professora se encarregava de conduzir os alunos para a sala. Era cerca de 20 alunos e boa parte deles ainda estava com a agitação do término da educação física e embalados pelas atividades do recreio que aconteciam no pátio. A pesquisadora querendo mudar o rumo da conversa perguntou a idade das crianças, a resposta da professora do segundo ano veio carregada de qualificações negativas de seus alunos, conforme mostra o trecho do caderno de campo.

"Ela me fazia perguntas (...) e fui tentando responder, já entrando na sala com ela e os alunos, imersa na gritaria das crianças, animadas pelas brincadeiras do recreio. Foi então que, querendo desviar da proposta do tal trabalho, perguntei a idade das crianças. Ela perguntou a todos, tentando falar mais alto que eles (...). Eles foram respondendo e a média de idade era de sete, oito anos (...). Enquanto [a professora] falava que as crianças eram 'malucas', que tinham 'problemas psiquiátricos' e que só falavam sobre 'sexo e violência',".

A conversa foi finalizada com a necessidade de tomar conta, sozinha, das crianças que gritavam e corriam na sala de aula.

\subsubsection{Quarto Episódio - escola 04: na sala da direção}

A presente escola está situada na favela que faz fronteira com o bairro e conta com mais de mil estudantes dos dois segmentos escolares distribuídos no 
turno da manhã e tarde. Os alunos, conforme consta no SCA, moram majoritariamente na favela onde está localizada a escola: menos de $1 \%$ deles não reside nesta comunidade. Ao recreio são reservados os espaços da quadra e do pátio, há fracionamento de espaço e de tempo. Isto é, não há recreio todos os dias para um mesmo ano escolar; se ele tiver recreio em um dia significa que no outro não terá. A justificativa é que os espaços da escola não comportam todos os alunos juntos.

\section{“moleque de rua, polícia resolve!".}

Devido à chuva, o recreio desse dia aconteceu apenas na quadra. Os alunos do sexto ano comemoravam o dia das crianças com um lanche especial feito pela professora. Sentada no banco de cimento, a pesquisadora observou as atividades que se desenrolavam no recreio, entre elas um grupo de meninas ensaiando para um festival. Além dos alunos e da pesquisadora, estavam na quadra três inspetores. Um deles saiu em direção a uma menina e um menino que brigavam por algum desses motivos que acontecem no recreio - não deu para registrar o motivo e de qual ano escolar pertenciam os estudantes. $\mathrm{O}$ inspetor prontamente pegou o menino pelo braço e o levou para a sala da diretora, ao contrário da menina que ficou no recreio. A pesquisadora acompanhou o adulto e a criança até à direção. Ao chegar à sala da direção com o aluno, o supervisor falou em um tom definitivo: "ele não vai mais ficar no recreio". Logo em seguida, antes mesmo da diretora se pronunciar, o inspetor qualificou o estudante dizendo que "moleque de rua, polícia resolve!”. Tentando entender o que estava acontecendo a diretora olhou para o menino e esperou uma resposta como se tivesse feito uma pergunta. Imediatamente o estudante disse que foi provocado por uma menina e, por disso, brigou com a colega. Como se buscasse uma cumplicidade, a diretora falou à pesquisadora que as meninas "são fogo", a pesquisadora não se segurou e opinou “tinha que chamar a menina também para conversar”. A diretora não gostou da intervenção e pediu que saísse da sala. Prontamente, atendeu à solicitação e voltou para a quadra onde ainda acontecia o recreio.

\section{A estagiária}


No dia seguinte, sétimo dia de observação, a pesquisadora chegou mais cedo à escola e, depois de pedir autorização para divulgar um seminário do grupo de pesquisa do qual faz parte, passou de corredor em corredor e encontrou um aluno parado que, segundo ele, estava de "castigo". Seguiu em direção ao pátio, hora do recreio, chegando lá conversou com alguns estudantes que estavam com os rostos pintados com giz, segundo eles, para ficar igual a "fantasma”. No pátio, tomando conta das crianças, havia três adultos: a porteira, a merendeira e uma professora. De repente, dois meninos começaram a brigar e, imediatamente, foram levados à direção. Mas a diretora não estava na escola e, então, uma professora foi acionada. A professora gritou para pararem de brigar e mandou os dois se abraçarem, sendo que um dos alunos se recusou a obedecer a devida ordem. Diante disso, a professora resolve pegar o braço desse aluno e colocar nos ombros do outro. O movimento é feito com uma fala: "você vai abraçar ele sim!”. Na sala da direção, além da professora e dos dois alunos, estavam uma funcionária da escola e uma senhora com uma camisa da SME (Secretaria Municipal de Educação) que se apresentou como estagiária para a pesquisadora. A funcionária responde à senhora, que naquele momento aplicava um questionário, dizendo que "os pais não vem à reunião mesmo sendo no sábado". Contudo, observando a professora saindo da sala e o aluno tirando o braço do ombro do outro, a estagiária parou de aplicar o questionário para conversar com os meninos:

- "por que vocês estavam brigando?”, pergunta a senhora-estagiária da SME.

- "porque ele tava implicando com minha prima" [aluno que tirou o braço do ombro de seu colega].

A senhora-estagiária falou para o aluno deixar de implicar com a prima do outro e pede aos dois um pedido de desculpa. Eles pediram desculpas um para o outro e, em seguida, saíram da sala da direção.

\section{A polícia na escola}


O episódio é focado em uma menina de nove anos e aconteceu na sala da direção. A pesquisadora, em último dia de observação, estava indo em direção à porta da escola quando resolveu passar na sala da diretora para agradecer. Na sala havia uma pequena movimentação de policiais da corporação Polícia Militar do Estado do Rio de Janeiro (PMERJ) e, como de costume, estavam com suas armas que, independente do lugar, impõem uma simbologia de enfrentamento. O lugar, desta vez, era a sala da direção escolar que recebia os policiais devido a um chamado da própria diretora para ajudá-la com uma questão de disciplina e a tarefa dos policiais era conversar com uma aluna. É que a aluna, no recreio, brigou com sua colega e, por esse motivo, foi levada à direção. Além da diretora, na sala estavam os policiais, uma funcionária, a aluna e a pesquisadora. Depois de a diretoria perguntar à pesquisadora se ela "nunca viu essa menina no recreio" e ter falado que "ela vive enforcando as crianças", um dos policiais foi conversar com a estudante e ouviu-se a seguinte frase: "não faz mais bagunça não, tá". Sem falar nada, a estudante escutou o policial e não tirou os olhos dos cadernos que estavam em cima da mesa. A conversa foi breve e os policiais se dirigiram à porta de saída da sala, antes de irem embora falaram à diretora que havendo necessidade era "só chamar novamente". Assim que saíram da sala chegou o pai da aluna bastante nervoso, brigou com ela e disse o seguinte: "Eu não te dei comida e suco e mandei você vir para a escola direito?" O que é que está acontecendo com você? Ou eu vou te matar ou vou sumir com você... ".

Em seguida, o pai levou sua filha para casa antes mesmo de terminar o dia na escola. Completando aquele desfecho, em que pai e filha iam saindo da escola, a aluna rasgava alguns papeis que estavam em suas mãos. Depois disso a pesquisadora foi embora.

\subsection{Eixo de análise: problematizando os episódios}

A presente seção faz uma análise dos episódios de recreio objetivando, de modo geral, problematizar o processo de socialização escolar desenvolvido nessas escolas, e, de modo específico, compreender as situações que podem ser 
reveladoras de propriedades da relação estabelecida entre a escola e o aluno morador de favela ${ }^{29}$.

Com base no que está posto no capítulo 01 dessa dissertação, uma das dimensões mais importantes colocadas pela sociologia contemporânea na reflexão sobre a socialização escolar é a comunicação como elemento central nas práticas institucionais. Na perspectiva da sociologia da experiência, por exemplo, a socialização escolar na atualidade é uma construção que passa pela valorização da própria heterogeneidade a qual pertencem os diferentes sujeitos. Essa heterogeneidade é um conjunto de indicadores contextuais que dizem respeito ao aluno e ao seu mundo, inclusive os referentes às dificuldades de aprendizagem e aos aspectos de uma vida, muitas vezes, valorativos de uma sociabilidade não escolar, como é o caso da sociabilidade da favela.

Para autores como Dubet e Martuccelli (1998), os enfrentamentos da escola nos dias atuais convocam os sujeitos a se tornarem coautores da socialização escolar. Trata-se, então, de um desafio que consiste em aumentar a capacidade das instituições de pautarem e qualificarem as interações pela comunicação, sugerindo um real encontro entre diferentes culturas em um mesmo meio. Nesse sentido, pode-se dizer que à escola tem se exigido uma abertura a fim de que sua prática de educar e ensinar valorize o dialogo com os seus estudantes, encarando-os como sujeitos de direitos. Então, parece ser importante que em cada escola, no seu contexto singular, haja acordos claramente estipulados sobre como resolver as tensões da relação entre gestores, professores e alunos no processo da socialização.

O registro do episódio 01 aponta para um processo de socialização escolar baseado no controle da sociabilidade dos alunos. A escola, como uma instituição formadora, procura construir uma disciplina que permita certa convivência no espaço-tempo do recreio, mas, a partir da posição estratégica de seus supervisores,

\footnotetext{
${ }^{29}$ Nossa pesquisa do tipo observação participante possui muitas limitações e, por isso, não podemos ir além de indicações daquilo que pode caracterizar a relação da escola com o seu público popular. No entanto, são indicações que se mostram importantes para problematizar a função da escola em uma sociedade como a brasileira, profundamente desigual, especificamente em um contexto social marcado pela segregação urbana como é o caso da cidade do Rio de Janeiro.
} 
é possível entender que a forma da escolar lidar com os alunos, moradores da Rocinha, parece ser por via da regulação. A regulação, nessa escola, não é resultante da afirmação do diálogo. Relembremos como essa dinâmica é estabelecida.

O contexto social do episódio é o seguinte: o adulto está no cenário, sublinhando a cena. É uma prática usual da escola a vigilância da convivência no recreio a fim de fazer prevalecer um ambiente pouco conflituoso, tanto na relação entre aluno e professor, como entre os próprios alunos. O adulto está sempre presente e atento para os riscos da desorganização e tudo indica que o recreio é um momento de definição da disciplina escolar, da introjeção de normas e de comportamentos.

Além dos imperativos de controle evidentes como a mobilização de pessoal para supervisionar a dinâmica do recreio, não podemos esquecer a existência do basculante que, intencionalmente ou não, serve de elemento à regulação do que acontece na lateral do prédio. Isto é, o basculante faz parte da rede simbólica de vigilância da diretora. A diretora representa uma mistura de dispositivos explícitos e implícitos da regulação mostrando que, sem ditar uma palavra, apenas com sua presença, faz valer um comportamento mais disciplinado dos estudantes. Não à toa os estudantes diminuíram por completo o volume do funk quando ela chegou à área lateral e, ao fazerem isso, mostraram também como as regras são exercidas.

Apesar dessa arquitetura, foi observado que os alunos sabem jogar com as regras da instituição. Pois, como não há rádio nessa escola, a ausência pode significar pouca abertura para a música coletiva no recreio, evidentemente a não ser a escutada em fones. Entretanto, os alunos encontraram uma "brecha" para tocar funk em uma caixa de som mesmo na presença dos supervisores escolares e da diretora adjunta. $\mathrm{O}$ funk no recreio apareceu como uma importante motivação da sociabilidade entre os alunos que estavam entorno do banco de cimento e essa ação sugere que se trata, de um lado, de simples "transgressão" às regras escolares, sem, contudo, ultrapassar as fronteiras do aceitável, e, de outro, de um modo particular de reivindicar um pouco da cultura de seu mundo na escola. É que a conversa sobre o baile funk que aconteceu no final de semana serviu de 
abertura para o estudante colocar a caixinha debaixo do banco, dando-lhe o play, a fim de explorar os gestos do ritmo musical realizados timidamente pelas meninas. Pode-se dizer, portanto, que a manifestação do jovem foi a de potencializar a interação com aquele grupo que fez referência a algo que os conecta, ao funk, a um código de comunicação e elemento cultural de seu mundo.

De certo modo, o episódio ajuda a compreender como as regras são sancionadas e exercidas nessa escola. A lógica desse episódio apresenta um posicionamento estratégico dos adultos de visualização da interação entre os alunos, enquanto estes assumem formas de utilizar e dinamizar o espaço e seu funcionamento, como é o caso do banco que se tornou, na hora do recreio, um lugar do lazer. Nesse sentido o episódio mostra que, embora haja pouca transgressão, esse espaço escolar não é desprovido de ressignificação.

Uma leitura possível desse episódio é que a comunicação entre a escola e seus alunos ainda carece de maiores ajustes. Nosso entendimento é que a qualidade da interação constitui passo fundante dos valores e moralidades sociais a serem desenvolvidos e afirmados na/pela escola. Uma escola que não é aberta à comunicação com seu aluno dificilmente vai contribuir para uma realidade social que exige as habilidades do diálogo, como se quer nas sociedades democráticas. Com base no segundo episódio, referente à escola 02, é possível problematizar ainda mais a necessidade de ajustes na comunicação entre os atores escolares.

Ao contrário da escola 01, cujo episódio “o funk no recreio" acabou de ser analisado, na escola 02 há pouca presença de adultos na dinâmica do recreio. De certo ponto de vista ter adulto presente na cena do recreio mostra que a escola tem alguma preocupação com esse momento, mesmo que sua justificativa seja a da ótica mais básica: a da preservação da escola ou da integridade física do aluno. O episódio 02, caso do boné, apresenta uma realidade situada no extremo da ausência de comunicação na relação entre a escola e seu público. Conforme vimos, trata-se de um exemplo emblemático de uma escola pouco habilitada a proteger seus alunos e evidentemente seus profissionais, e fala ainda de uma precariedade de pessoal que permeia todas as relações e regras estabelecidas. Pois, na falta de um supervisor escolar é mais difícil fazer valer aquilo que é tido como modo de convivência na escola, no caso desse episódio não usar boné. Embora no 
episódio não haja registro de que é proibido o uso do boné, apenas implicitamente, o professor agiu como se estivesse buscando o cumprimento dessa regra e ao exigir foi desmoralizado na frente de outros estudantes, em meio ao recreio, por aquele que prontamente peitou seu comando.

A situação vivida pelo professor deixa bastante evidente a baixa institucionalidade da escola, com dificuldade de estabelecer disciplina, hierarquias e, até mesmo, funções no seu interior. O professor, totalmente desamparado, potencializa, o mínimo que seja, a descrença na afirmação de alguma regularidade construída pela escola. Na ausência de regulação da sociabilidade, as relações dependem mais de uma camaradagem, de um "jogo" pautado pela informalidade que se apresenta como base para construir alguma autoridade. A autoridade institucional, aquela construída coletivamente com regras claras e meios de consolidá-las, foi testada pelo professor que, na falta dela, não soube contornar a situação.

Como se percebe, ganha importância cada vez maior o que efetivamente acontece no interior da escola, por exemplo: a maneira como se dão as tomadas de decisões; a forma do professor se relacionar com seu aluno; como a regulação do espaço da escola é concebida; e etc... O estudante é sujeito ativo nas práticas escolares e, nesse episódio, a escola parece está desatenta para essa questão quando o professor tenta agir com as substâncias de um modelo impositivo da prática pedagógica, isto é, usa de uma autoridade que prontamente é questionada. A principal finalidade do professor foi a de exigir de seu aluno o cumprimento de uma disciplina que diz respeito à convivência na escola: a não utilização do boné. Contudo, sua reivindicação não resultou em muitas conquistas e isso deve tanto a maneira de como o professor se comunicou com o aluno, como também pelo fato dessa escola carecer de mecanismos mais eficazes de controle. Lembremos, por ocasião desse segundo ponto, vimos que o perfil institucional da escola brasileira passou por um processo de fragilização (veja o desenvolvimento dessa questão no capítulo 02), cuja marca mais refinada parece estar na interação entre a escola e seu público. Podemos ainda dizer que até mesmo a disciplina exigida pela/na escola não é mais algo estipulado verticalmente, pelo contrário, passa a ser algo construído necessariamente com os próprios estudantes. 
Como bem assinalou Durkheim (2011), ao pensar a função da escola na sociedade moderna, o professor como porta-voz da sociedade adquire uma qualidade de agir com autoridade que tem a ver com o tempo de sua sociedade. É certo que a sociedade moderna, tal como vimos em Durkheim no capítulo 01, encarrega à escola a função de socializar valores comuns para a vida em uma sociedade onde os papeis sociais eram mais claramente definidos, o que não significa ausência de tensões na relação desses papeis. $\mathrm{O}$ fato é que professor e aluno na escola da sociedade moderna são atores que têm por trás uma forte instituição, ao passo que na escola dos dias atuais, como a que serviu para o desenrolar do episódio do boné, o poder da instituição está na capacidade de haver uma relação menos assimétrica entre os seus atores. Sobre a questão da relação assimétrica na escola, o episódio do papel higiênico ajuda a entender bem alguns pontos de sua face.

Primeiro vale dizer que estamos cientes de que nada na escola é fácil. Sabemos que o quadro da escola brasileira assume marcas de uma enorme complexidade, com variações no suporte institucional (como a baixa capacidade de recursos humanos e materiais) e nas interações entre os seus atores. Os trechos das conversas captadas na observação do recreio dessa mesma escola do episódio do boné ajudam a qualificar esse dois pontos. Como vimos, o caso do papel higiênico é revelador da condição mínima de higienização dos alunos na escola, marcada principalmente pela falta de papel higiênico nos banheiros, e essa condição mínima de higienização aparece também na falta de sabonete e de manutenção da descarga para o uso das alunas. Entendemos que essas informações ratificam a argumentação de Cavaliere (2009) da falta de material e de condições adequadas para os alunos (e também para os professores) das escolas públicas. Além disso, o episódio mostra que os limites do investimento nesses recursos aparece no breve diálogo entre a diretora e seu aluno. Nesse momento, porém, o que sobressai é a assimetria da relação.

É importante ressaltar que essa assimetria fala de uma distância permeando a forma da escola lidar com os seus estudantes. A distância é vista com mais ênfase na maneira como a diretora termina a reclamação do aluno: batendo o jornal em sua bunda e mandando que suba para a sala de aula. Não esqueçamos 
que esse movimento é precedido por uma fala que menospreza o questionamento do estudante sobre a finalidade daquele carregamento de papel higiênico que acabara de chegar. Esses dados são duas evidências que falam da forma fragilizada de a escola se relacionar com o seu público. Não se trata de apresentar culpado ou vítima das situações escolares, as quais são profundamente complexas, mas apontar que há uma lacuna entre a escola e o seu público, entre professor e aluno que precisa ser resolvida.

Outra leitura que pode ser extraída dos episódios dessa escola é que, apesar de estar dentro da escola, falta um compromisso mais escolar que possa servir de fio condutor das relações. Ou melhor, é preciso problematizar como o conhecimento - a aprendizagem - pode pautar a relação entre professores e alunos. É claro que afirmar esse compromisso com poucos funcionários é muito mais difícil, ainda mais em uma escola que atende acima de mil alunos; faz-se necessário uma quantidade adequada de pessoal e qualificada para o exercício das práticas pedagógicas. Contudo, um compromisso mais escolar permeando as dinâmicas impede que um professor saia discutindo com um aluno a ponto de quase travar uma luta corporal no meio do recreio, como também impede uma diretora de dar uma "tapa" com jornal no aluno - uma ação simbólica que fragiliza a sua própria autoridade. Além disso, a escola vai estar mais prevenida para regular a sociabilidade entre os estudantes, a começar por ditar que é proibido bisbilhotar o banheiro feminino, e, evidentemente, ficar mais atenta às críticas e reivindicações de seus estudantes.

O episódio 03 apresenta uma situação que parece ser corriqueira para a professora de educação física, isto é, ter que separar sua aula da atividade do recreio e ministra-la em um dos momentos mais tumultuados da escola, já que a sensação de estar em recreio é a aquela marcada por brincadeiras, correrias e gritos. Com pouco profissionais para ajuda-la, o momento de dar aula se configura como um tormento para essa professora do segundo ano, sendo a transição do pátio para a sala de aula o auge dessa complicação, pois a professora precisa conduzir (sozinha) os alunos de volta para dentro do prédio. O episódio mostra que o momento da volta para a sala de aula é cheio de tensão, e a sua marca mais 
emblemática se revela na forma de palavras brutas soltadas aleatoriamente pela professora.

A essa condição de precariedade infraestrutural, representada pela divisão do exíguo espaço e falta de suporte de pessoal para marcar a separação de uma e outra atividade, registra-se uma vulnerabilidade que fala da situação da professora. A sua inciativa de conversar com a pesquisadora objetivou envolvê-la em alguma atividade extra que não diz respeito a questões escolares. Ao fazer isso a professora mostra o dispêndio de um esforço que poderia ser usado para gerar mais envolvimento com a instituição escolar, o que talvez evitasse afirmações (intencionalmente ou não, mas perversas) do tipo: esses alunos têm "problemas psiquiátricos"; só pensam em "sexo e violência". Conforme o episódio, podemos dizer que, por um lado, há um distanciamento da professora em relação à escola, e, por outro, também há uma relação com o mundo do aluno permeada por uma informalidade fundada em disposições negativas.

Os casos do episódio 04 apresentam muitos pontos em comuns com os anteriores, sendo que há algo de mais dramatizador: a presença da polícia na escola. É talvez uma especificidade que tem a ver com o lugar onde está localizada a escola, numa favela, mas uma favela que conta com uma Unidade de Polícia Pacificadora (UPP) recentemente instalada e que foi colocada à disposição de outras instituições do Estado, inclusive da escola.

No primeiro episódio da escola 04 é interessante notar como o recurso à polícia foi usado pelo inspetor para dar fim a um problema de briga no recreio entre um menino e uma menina. Com elevado grau de discricionariedade, na sala da diretora, o inspetor qualifica o estudante como "moleque de rua" que, além do claro deslocamento do papel social do estudante, expressa uma forte fronteira entre o espaço da escola e o da rua. Na escola, pode-se exigir um direito às normas vigentes para aqueles que lhes pertencem; na rua, embora existam regras, constata-se ser mais difícil fazer valer essas exigências por se tratar de um espaço desprovido de maiores garantias, um local de baixo grau de controle. O estudante, agora menino, é jogado na rua pela sua própria escola; é jogado à sua própria sorte em um universo onde o seu direito aparece mais obscuro. 
A polícia aparece ainda em outro dia, no último da observação, quando é convocada pela diretora para conversar com uma menina de nove anos que também brigou no recreio. Briga no recreio talvez não seja novidade para todos nós, mas acionar a polícia para solucionar esse tipo de episódio talvez sim, salvo em situações mais extremas, o que não parece ser o caso desse episódio. A diretora chamou a polícia por se tratar de uma "situação especial", envolvendo uma aluna que "vive enforcando as crianças" no recreio. Com essa ação a escola abdica de suas próprias ferramentas, mais pedagógicas, de encarar a regulação da sociabilidade no seu espaço e de dar uma resposta mais educativa à aluna que, conforme a fala da diretora, sofre de algum transtorno psicológico. Uma pergunta: não seria o Conselho Tutelar o ator externo mais adequado para ajudar a escola em situações desse tipo?

Do ponto de vista institucional, o simples acionamento da polícia para conversar com uma aluna com aparente problema psicológico representa duas dimensões de um mesmo problema: a primeira, é a diminuição do poder institucional da escola frente à instituição policial, admitindo a autoridade policial intervir na dimensão pedagógica; a segunda dimensão é mais perversa para a aluna: trata-se da representação simbólica da polícia dentro da escola para uma criança moradora de favela, um lugar marcado, historicamente, pela brutalidade das incursões das forças de segurança do Estado.

Os três casos do episódio 04 mostram que a orientação parece ser a de "brigou, leva à direção", forma encontrada pela escola para resolver os conflitos no pátio, na quadra, enfim, onde acontece o recreio. Portanto, a sala da direção é um espaço onde vão parar os problemas de briga dos alunos no recreio. Mas ir à direção não significa que tudo será resolvido pela diretora, pode mesmo ser solucionado por alguém que, conforme vimos no episódio, encontra-se "aplicando um questionário". Aliás, essa pessoa que aparece no episódio como estagiária da SME conseguiu fazer o que a professora, convocada, tentou realizar: fazer com que os estudantes fizessem as pazes. O fato é que o tom da comunicação utilizado pela estagiária não foi o da professora, que se impôs: "você vai abraçar ele sim!".

Aliada à precariedade que caracteriza boa parte das nossas instituições escolares, a comunicação na escola pública brasileira talvez seja uma das 
dimensões mais problemáticas dos efeitos do processo de universalização do ensino fundamental. Um espaço social em que a comunicação seja bem resolvida quase não tem abertura para falas que colocam em jogo qualificações referidas a contextos pouco equitativos. Por comunicação bem resolvida se entende diálogo entre os atores em situações sociais específicas e diálogo pressupõe sujeito de direitos.

Os episódios de recreio das quatro escolas apresentadas acima falam de diferentes modos de a instituição escolar lidar com o estudante do mundo popular, em especial o morador de favelas. O espaço-tempo do recreio aparece como um momento de maleabilidade, uma vez que, na falta de formas padronizadas, as escolas usam de mais critérios pouco institucionalizados para imprimir estratégias de adaptação em cada situação. Mas são estratégias que colocam em prática diferentes modos de autoridade e de comunicação, muitas vezes desqualificando o aluno como sujeito de direitos, logo, jogando contra a socialização escolar portadora do projeto democrático.

Este capítulo apresentou episódios de recreio que nos ajudam a pensar sobre a forma, ou as formas, de a escola se relacionar com o seu público, mostrando que essa questão é uma importante dimensão do processo educacional em curso no Brasil, especificamente em contextos sociais marcados pela segregação urbana. Os termos dessa relação problematizam a construção de um ambiente socializador, onde a construção do indivíduo e da sociedade se realiza na medida mesmo do sucesso da socialização. Por outro lado, não podemos esquecer que são dependentes da qualidade da interação não só o próprio direito de escolarização, mas também a base sobre a qual se poderá erguer uma realidade mais equitativa. 


\section{Considerações finais}

Em primeiro lugar, quero dizer que as questões básicas da sociologia me atraem desde meados da graduação. Essa atração corresponde, especialmente, a uma necessidade de compreender bem a sociologia, o que me parece ser um exercício difícil e frequentemente desvirtuado por uma prática do pensamento de simplificação da realidade social. Acho que é preciso "cavar" bastante na arena da sociologia para melhor se apropriar de suas ferramentas e, desse modo, contribuir com um processo de construção do conhecimento, o qual pode estar a serviço de diferentes horizontes: o meu é uma sociedade menos desigual. Quero dizer, então, do ponto de vista do conhecimento, que minha posição hoje é a de quem se vê desafiado a enfrentar questões de base, para ter a meu favor um conjunto de apropriação que oriente um olhar capaz de problematizar uma certa naturalização. Acho que essa dissertação, de certo modo, faz um primeiro ensaio em torno dessa preocupação, tanto que apresentei ao meu orientador primeiro um capítulo que pretendeu pensar a socialização escolar. Então, embora não se tratasse de uma afirmação tão clara, acho que estava querendo encarar uma questão constituinte da sociologia. Esse desafio exigiu muito do orientador, pois dissertar sobre questões constituintes da sociologia não é fácil, e, principalmente, porque na minha cabeça as questões sociológicas brasileiras ainda são muito complexas, o que pra mim é natural, pois, conforme Wright Mills, acredito que fazer sociologia é um artesanato que se aprimora mexendo muito no objeto.

O objeto central deste trabalho foi a socialização produzida pela escola. Além de atender à preocupação de encarar uma questão básica da sociologia, como foi colocado, penso que estudar a socialização escolar possa ser uma via privilegiada de compreensão e problematização do modelo de sociedade em vigor. No caso brasileiro, essa questão parece ser ainda mais interessante de ser pensada porque a escola para a grande massa da população é uma aposta de poder formar cidadãos que construam uma sociedade globalizada, democrática e igualitária. Isto é, conforme a Constituição Federal de 1988, o papel conferido à escola é o de ser 
uma instituição capaz de ensinar - para uma sociedade que exige qualificação para o trabalho - e de educar - para o fortalecimento da democracia.

Diante disso, sabendo que a escola passou a fazer parte da vida de todas as crianças, investigar a socialização escolar é uma preocupação sociológica que, me parece, permitir acessar o próprio sentido da nossa atual escola pública: o que ela efetivamente é capaz de produzir? Não esqueçamos que, conforme John Meyer (1977), ao ganhar uma enorme centralidade a escola torna-se um forte ator nos mecanismos globais de seleção, conferindo fracasso e sucesso aos indivíduos que passaram e aos que não passaram por ela. Quer dizer, então, a expansão da socialização escolar a todas as crianças é um processo que também tornou a escola uma poderosa instituição, pois, no limite, ela chancela a experiência social dos indivíduos.

Mas esse processo de difusão da escola e, consequentemente, de universalização do ensino desafia o trabalho de escolarizar os indivíduos de diferentes camadas sociais. Na realidade o que está em jogo, como foi colocado por Bourdieu e Passeron (1975) no capítulo 02 e também por Néstor López (2005) no capítulo 01, é a capacidade da escola de ofertar aos grupos sociais mais prejudicados em capitais (materiais e simbólicos) a efetiva participação do processo educativo formal: no limite, equidade ao saber escolar. Esse desafio é posto pela universalização do ensino que, de modo geral, complexificou o papel e a potencialidade da escola nos dias atuais, e, de modo específico, especialmente no caso brasileiro, redesenhou o perfil institucional da escola (cf. capítulo 03) produzindo mudanças profundas nas interações escolares (cf. capítulo 04) que, no limite, aprofundam o quadro de desigualdade educacional. Então, vale ressaltar o seguinte: se a universalização do ensino diversificou a entrada na escola, permitindo grupos antes excluídos da socialização escolar ingressar nessa instituição, ela também consagrou a escola pública como a escola dos pobres, e, nesse sentido, o que está colocado é a capacidade de a escola articular 
conhecimento com o contexto social de seus alunos a fim de evitar que o acesso à escolaridade se traduza em expansão ou aprofundamento das desigualdades ${ }^{30}$.

Pois bem, é a partir da articulação escola e democracia que a instituição escolar assume crescente protagonismo na socialização das crianças e adolescentes do mundo popular. Mas, como vimos no capítulo 03, a entrada da classe popular na escola, ou a massificação da escolarização fundamental, produziu profundas mudanças na natureza da própria instituição escolar e, consequentemente, na qualidade de seu trabalho. Do ponto de vista sociológico, o resultado mais preocupante dessa mudança é o fenômeno de o acesso à escola se configurar como um meio para a emergência de novas precariedades na sociedade brasileira.

Isto é, uma questão social importante dos contextos democráticos atuais é a capacidade de os novos processos educacionais tornarem-se excludentes e agravadores das desigualdades sociais. Essa questão é claramente levantada por Castel, Kessler, Murard e Merkelen (2013), ainda que ao longo da dissertação o trabalho deles não tenha sido mobilizado. Segundo esses autores, baseados em evidências empíricas, o mundo popular é profundamente afetado pelas formas precárias de inserção no mercado de trabalho e de formação da cidadania. E essa realidade não deixa de falar sobre formas insuficientes de inscrição coletiva, como a desenvolvida pela socialização escolar, sendo o seu principal efeito a emergência de um "individualismo popular". Segundo os autores, esse “individualismo popular" está longe de equivaler a formas de autonomia e liberdade, na verdade resulta da instabilidade e da impossibilidade institucional de forjar um acesso coletivo aos recursos do progresso. Trata-se de um processo de desinstitucionalização, que diz respeito aos déficits institucionais que afetam de modo particular os mais pobres, principalmente em contextos latinoamericanos.

\footnotetext{
${ }^{30}$ Contudo, compreender essa questão não significa neutralizar a critica sociológica que enfatiza que os problemas da escola são limites que fogem de sua capacidade. Isto é, no centro dessa crítica, o que está em jogo é o seguinte: a sociedade na qual a escola está inserida deseja uma efetiva integração das classes populares? Essa é uma importante questão sociológica, mas o presente trabalho se concentrou em abordar a outra parte do problema escolar.
} 
Para esses autores a desinstitucionalização apresenta a necessidade de reinstitucionalizar as instituições sociais, por exemplo, a escola. Essa perspectiva sociológica coloca uma premissa básica, a fim de explorar ainda mais essa interpelação: determinar quais as normas de institucionalização são fundamentais à escola. Essa premissa parece desafiar bem a escola brasileira, caso concordemos com o seu quadro apresentado no capítulo 03 e caso tomemos as situações observadas nos episódios de recreio (capítulo 04) como uma revelação das condições pedagógicas por se construir. Quer dizer, de um lado, a socialização escolar de crianças e adolescentes do mundo popular brasileiro esbarra em elementos externos à escola, que dizem respeito à responsabilidade do Estado na afirmação de uma instituição precarizada ao impulsionar a desescolarização da escola (PEREGRINO, 2010 - cf. Capítulo 03); de outro, em questões internas, como a dificuldade de lidar com os contextos sociais dos alunos, como vimos no capítulo 04. Ao que parece, essas duas dimensões sugerem uma necessidade: a afirmação de normas e práticas de institucionalização. Esse é um ponto que precisa ser explorado muito mais pelas pesquisas educacionais.

O que esse trabalho pode apontar é que, de certo modo, a dificuldade de construir uma socialização escolar forte no Brasil está ancorada nos limites da instituição "Escola", que ainda não sabe lidar com os elementos da cultura do mundo das crianças e adolescentes populares. No entanto, e embora saibamos que a trajetória de afirmação da escola pública para o segmento mais pobre da população evidencia uma fragilização do projeto republicano, não podemos perder de vista a capacidade da instituição escolar de alimentar uma interação com seu público a fim de tornar a experiência do mundo popular uma potencialidade para a socialização escolar. Com efeito, cabe à escola ser guardiã de um conjunto de práticas que institucionalize uma maior aproximação com os seus alunos de modo a não se tornar seletiva, chancelando a desigualdade existente na sociedade brasileira e forjando novas precariedades.

A crítica à escola presente neste trabalho deve ser entendida como uma defesa de um projeto de seu fortalecimento para a mudança das condições subalternas; para a replicação dos valores democráticos e empoderamento dos indivíduos. Por outro lado, reconhece-se o fato de que essa relação escola e 
democracia não é algo naturalmente dado. Como vimos no capítulo 04, os episódios de recreio apontam uma tensão inerente a essa relação, uma vez que, em grande medida, a interação na escola é marcada pela condição social do aluno: a de morador da favela. Dito de outro modo, os episódios mostram uma tensão entre a cultura da escola e a cultura dos alunos moradores de favelas que acaba produzindo o efeito de um distanciamento dos princípios democráticos, entre os quais o da equidade social. O que dizer da maneira como a escola lida com a forma desajeita da fala de um estudante que tenta reivindicar algo? (ver segundo episódio caso do papel higiênico).

A mudança desse quadro, pode-se arriscar, pressupõe uma maior abertura da instituição escolar a fim de se aproximar do mundo de seu aluno, sem abandonar o seu projeto de ensinar e educar, mas colocando a socialização escolar numa dimensão relacional. A aproximação com o mundo do aluno fala em uma clara comunicação estabelecida com o estudante, de modo que o valorize enquanto sujeito (cf. DUBAR, 2005; DUBET \& MARTUCCELLI, 1997; DUBET, 1998).

Esses autores mobilizados no capítulo 02 enfatizam que a socialização escolar se trata de um processo construído na interação, desde que se considerem as especificidades trazidas pelos alunos. No caso brasileiro, a perspectiva microssociológica se apresenta como uma alternativa de mudar a experiência escolar de crianças e adolescentes do mundo popular, tornando-a algo que não seja aquilo que repudiamos: integração pela margem. É claro que devemos ser cuidadosos na contundência da afirmação de que a instituição escolar integra somente pela margem, deixaríamos de reconhecer o esforço de muitos profissionais da escola que buscam constantemente evitar esse desfecho. Porém, os episódios de recreio dão indícios de uma socialização escolar onde há pouca reciprocidade de expectativas, e esse formato pode gerar uma integração precarizada na sociedade.

Vale ressaltar, então, que uma das preocupações deste trabalho é a de ver se realizar uma cultura escolar que afirme o pacto democrático com o mundo popular, especificamente na relação entre professor e aluno, entre a escola e a 
família. Daí a aposta nas interações específicas; na aproximação com o mundo do aluno, cuja natureza não é apenas a de uma estratégia pedagógica, mas uma forma de construir um ambiente institucional em que o estudante é entendido como sujeito de direito. Por mais difícil que seja a realidade das nossas escolas públicas, não podemos esquecer que o estudante é um papel social que age segundo os valores afirmados na instituição escolar, segundo a força de uma cultura escolar capaz de estabelecer acordos e construir uma base para a reciprocidade entre os atores. Nesse sentido, cabe bem dizer que a aproximação com o mundo do aluno, quando bem realizada, consiste em pactuar responsabilidades a fim de tornar o processo educacional menos vulnerável aos efeitos negativos da cidade, como a segregação urbana pela qual a favela é vista.

Pois, se por um lado a escola tem uma representação do aluno morador da favela, por outro não podemos perder de vista que o mundo popular traz consigo uma representação da escola que, em alguma medida, corresponde a sua condição de subalternidade na sociedade: será que ele se sente pertencente ao espaço escolar? São duas vias que registram a precariedade institucional da escola pública, muitas vezes sujeita aos efeitos da segregação social e, com isso, colocase como forjadora de experiências escolares marcadas por tensões daí decorrentes.

Desse modo, a preocupação normativa desta dissertação é chamar atenção para o adiamento da efetiva afirmação da equidade escolar/social no Brasil (sobre como esse adiamento tem acontecido ver o capítulo 03). Uma vez que, conforme o capítulo 04, os episódios de recreio indicam uma variabilidade da socialização escolar que não é equivalente à capacidade da escola de ofertar aos alunos das classes populares a possibilidade de experimentar igualmente as instituições e as potencialidades educacionais atuais.

Para finalizar, vale ressaltar a potencialidade que o espaço-tempo recreio tem para explorar dilemas escolares. O recreio é uma parte importante da rotina escolar e sua dinâmica pode ser reveladora da própria relação escola e sociedade, assim como poder nos falar sobre indicadores mais contextuais de uma determinada comunidade escolar. No nosso entendimento o recreio é uma via estratégica de investigação da capacidade da escola em desenvolver a habilidade 
de lidar com a cultura do aluno, evidentemente, buscando realizar sempre a sua função de escolarizar. Finalmente, apesar de ter algumas limitações, a nossa pesquisa aponta para importantes indícios a esse respeito. 


\section{6}

\section{Referências bibliográficas}

ALGEBAILE, Eveline. Escola Pública e pobreza no Brasil: a ampliação para menos. Rio de Janeiro: Lamparina, FAPERJ, 2009.

AZEVEDO, Fernando de. A Reconstrução Educacional do Brasil: ao povo e ao governo. Manifesto dos Pioneiros da Educação Nova. Rio de Janeiro, 1932

Manifesto dos Educadores: mais uma vez convocados (1959). Ministério da Educação, 2010.

BECKER, Howard. Segredos e Truques da Pesquisa. Zahar Editores, 2007.

BOURDIEU, Pierre. Razões Práticas: Sobre a teoria da ação. Campinas: Ed. Papirus, 1996. Misérias do Mundo, Vozes, 1997.

BOURDIEU, Pierre; PASSERON, J. C. A reprodução. Elementos para uma teoria do sistema de ensino. Rio de Janeiro: Francisco Alves, 1975.

BURGOS, Marcelo. Escola Pública e Segmentos Populares em um Contexto de Construção Institucional da Democracia. Revista Dados, 2012, vol. 54 nº 4.

BRASIL. Lei de Diretrizes e Bases da Educação Nacional - LDB Lei nº 9394/96. 
CASTEL, Robert; KESSLER, Gabriel; MURARD, Numa; MERKELEN, Denis. Individuacion, precariedad y inseguridad. Buenos Aires: Paidós. (2013).

CAVALIERE, A.M. Escolas de tempo integral versus alunos em tempo integral. In:

Em Aberto, Brasília, Inep, v.22, nº 80, p.51-64, 2009

CHABBOTT, Colette; RAMIREZ, Francisco. Development and Education. IN: Handbook of the sociology of education/edited by Maureen T. Hallinan. Library of Congress Cataloging-in-Publication Data: 2000.

DAMATTA, Roberto. A Casa \& A Rua: espaço, cidadania, mulher e morte no Brasil. Rio de Janeiro. Editora Rocco, $5^{\circ}$ edição. 1985

Carnavais, malandros e heróis: para uma sociologia do dilema brasileiro. Rio de Janeiro. Editora Rocco, $7^{\circ}$ edição. 1997

DAVIES, Brian. Bernstein, Dukheim e a sociologia da educação na Inglaterra. Cad. Pesqui., São Paulo , n. 120, Nov. 2003 . Available from http://www.scielo.br/scielo.php?script=sci_arttext\&pid=S0100157420030003000 04\&lng=en\&nrm=iso. $\quad$ access on 28 Aug. 2013. http://dx.doi.org/10.1590/S01001574200300030000

DEWEY, John. Democracia e Educação. Introdução à Filosofia da Educação. 4ed. São Paulo: Companhia Nacional, 1979.

DIAS, Fernando C. Durkheim e a Sociologia da Educação no Brasil. Em Aberto. Brasília, ano 9, n. 46. Abr/jun 1990. Disponível em emaberto.inep.gov.br/index.php/emaberto/article/view/726/649

DUBAR, Claude. A socialização: construção das identidades sociais e profissionais. São Paulo: Martins Fontes, 2005.

DUBET, François. O que é uma escola justa? - A escola das oportunidades. São Paulo: Cortez, 2008.

DUBET, François; MARTUCCELLI, Danilo. A socialização e a formação escolar. Lua Nova, São Paulo , n. 40-41, Aug. 1997 . Available from 
<http://www.scielo.br/scielo.php?script=sci_arttext\&pid=S010264451997000200

011\&lng=en\&nrm=iso $>\quad$ access on 29 Nov. 2013. http://dx.doi.org/10.1590/S010264451997000200011.

En la escuela: sociologia de la experiência escolar. Buenos Aires: Losada, 1998.

DURKHEIM, Émile. As Formas Elementares da Vida Religiosa: o sistema totêmico da Austrália. Tradução: Paulo Neves. São Paulo: Martins Fontes, 1996.

Da Divisão do Trabalho Social. Tradução: Eduardo Brandão. São Paulo. Editora Martins Fontes, 2010.

Educação e sociologia. Tradrução: Stephania Matousek. $2^{\mathrm{a}}$ ed. - Petrópolis, RJ: Vozes, 2011.

FREITAG, Bárbara. Dialogando com Jürgen Habermas. Rio de Janeiro: Tempo Brasileiro, 2005.

GIDDENS, Anthony. A constituição da sociedade. Trad. Álvaro Cabral. São Paulo, Martins Fontes, 1989.

As Consequências da Modernidade. São Paulo: Ed Unesp,

1991.

Política, Sociologia e Teoria Social: encontros com pensamento clássico e contemporâneo. Tradução: Cibele Salíba Rizek. São Paulo: Fundação Editora da UNESP, 1998.

Sociologia. $4^{\mathrm{a}}$ edição. Porto Alegre: Editora Artmed, 2005.

GOFFMAN, Erving. Constrangimento e organização social. In. Ritual de Interação: ensaios sobre o comportamento face a face. Goffman, Erving. Editora Vozes, Petrópolis, 2011. Tradução de Fábio Rodrigues Ribeiro da Silva.

LAHIRE, Bernard. Sucesso Escolar nos Meios Populares. In. As Razões do Improvável, São Paulo, Editora Ática, coll. «Fundamentos », 1997, 368 p. 
LEVI-STRAUS. "Aula inaugural”. In: O estruturalismo de Lévi-Strauss. Petrópolis: Vozes, 1970

LÓPEZ, Néstor (2005). Equidad educativa y desigualdad social: Desafios de la educación en le nuevo escenario latinoamericano. Buenos Aires: Instituto Internacional de Planeamiento de la Educación - UNESCO, 2005.

MANNHEIM, K. Ideologia e Utopia. Tradução: Sérgio Magalhães Santeiro. $4^{\mathrm{a}}$ edição. Rio de Janeiro: Guanabara, 1986.

(1951) A educação como técnica social. In. FORACCHI, M.

M; PEREIRA, L. Educação e Sociedade: leituras de sociologia da educação. $3^{a}$ ed.

São Paulo, Editora Nacional, 1967.

(1954). Funções das gerações novas. In. FORACCHI, M. M;

PEREIRA, L. Educação e Sociedade: leituras de sociologia da educação. $3^{\mathrm{a}}$ ed. São Paulo, Editora Nacional, 1967.

MARX, Karl. Teses sobre Feuerbach (1845). Ed. Eletrônica. Ed Ridendo Castigat Mores. Rocket Edition, 1999.

MARX, K. ENGELS, F. O Manifesto Comunista. São Paulo: paz e terra, 1997.

A ideologia alemã: crítica da mais recente filosofia alemã em seus representantes Feuerbach, B. Bauer e Stiner, e do socialismo alemão em seus diferentes profetas (1845-1846). São Paulo: Boitempo, 2007. 614 p.

MEYER, Jhon. The Effects of Education as na Instituion. The American Journal of Sociology, Vol. 83, No. 1 (Jul., 1977), pp. 55-77. Disponível em: http://kieranhealy.org/files/misc/meyer-effects77.pdf

MILLS, C. W. Sobre o artesanato intelectual e outros ensaios. Rio de Janeiro: Jorge Zahar Ed, 2009.

MOCHCOVITCH, Luna Galano. Gramsci e a Escola. Ed. Ática: São Paulo, 1988.

NOGUEIRA, M ${ }^{a}$ Alice; CATANI, Afrânio (orgs). Escritos de Educação. Petrópolis: Vozes, 1998. 
NÓVA, Antônio. Tempos da Escola no Espaço Portugal-Brasil-Monçambique: dez digressões sobre um programa de investigação. Revista Brasileira de História da Educação, no 1, jan/jun 2001. Acesso 08/2013 Disponível em http://moodle.fct.unl.pt/pluginfile.php/122509/mod_resource/content/0/Leituras/D ominique Julia.pdf

NÓVOA, António; SCHRIEWER, Jürgen (eds.) (2000). A difusão mundial da escola: Alunos, Professores, Currículo, Pedagogia. Lisboa: Educa.

PAIVA, Angela. Cidadania e formas de solidariedade social na favela. In. PAIVA \& BURGOS, Marcelo (orgs). A Escola e a Favela. Rio de Janeiro: Editora Pallas/PUC-Rio, 2009.

PEREGRINO, Mônica (2010). Trajetórias desiguais: Um estudo sobre os processos de escolarização pública de jovens pobres. Ed. Garamond, 2010.

ROMANELLI, Otaíza de Oliveira. História da Educação no Brasil: (1930/1973). 4. ed.

Petrópolis: Vozes, 1984

SAVIANI, Dermeval. Pedagogia histórico-crítica: Primeiras aproximações. 2. ed. São Paulo: Cortez/Autores Associados, 1991.

O Legado Educacional do Século XX no Brasil. São Paulo: Autores Associados Ltda., 2004.

SCHWARTZ, Lilia Moritz; BOTELHO, André (org.). Um Enigma Chamado Brasil: 29 Intérpretes e um País. São Paulo. Companhia das Letras, 2009. BOTELHO, André

SCHWARTZMAN, Simon; BOMENY, Helena M.B; Costa; VANDA M. R. (2000). Tempos de Capanema. $2^{a}$ edição, Fundação Getúlio Vargas e Editora Paz e Terra, 2000.

SETTON, Maria Graça Jacintho. Teorias da socialização: um estudo sobre as relações entre indivíduo e sociedade. Educ. Pesqui., São Paulo, v. 37, n. 4, Dec. 2011 Available from <http://www.scielo.br/scielo.php?script=sci_arttext\&pid=S1517- 
97022011000400003\&lng=en\&nrm=iso > access on 26 Set. 2013. http://dx.doi.org/10.1590/S1517-97022011000400003.

SILVA, Pedro. Escola-Família, Uma Relação Armadilhada - Interculturalidade e Relações de Poder. Biblioteca Ciências do Homem; Edições Afrontamento; Porto, 2003.

TELLES, Sarah Silva. Pobreza e Desigualdade da escola na Favela. In. PAIVA \& BURGOS, Marcelo (orgs). A Escola e a Favela. Rio de Janeiro: Editora Pallas/PUC-Rio, 2009.

THIN, Daniel. Para uma análise das relações entre famílias populares e escola: confrontação entre lógicas socializadoras. Rev. Bras. Educ. [online]. 2006, vol.11, n.32, pp. 211-225. ISSN 1413-2478.

TOURAINE, Alain. Poderemos viver juntos? Iguais e diferentes. Petrópolis: Vozes, 2003.

WEBER, Max. A Ética Protestante e o Espírito do Capitalismo. Tradução: M. Irene J. M. K. Szmrecsanyi e Tamas J. M. K. Szmrecsanyi. $4^{a}$ Edição. São Paulo: pioneira, 1985.

VINCENT, Guy; LAHIRE, Bernard; THIN, Daniel. Sobre a história e a teoria da Forma Escolar. Educação em Revista, n. 33, p. 7 - 47, jun. 2001. 